\title{
HIDROGEOLOGIA EM MEIO URBANO. REGIÃO E CUIABÁ E VÁRZEA GRANDE-MT
}

\author{
RENATO BLAT MIGLIORINI
}

Orientadora: Prof f- $^{\text {- }}$ - ${ }^{\text {a. }}$ Annkarin Aurelia Kimmelmann e Silva

TESE DE DOUTORAMENTO

COMISSÃO JULGADORA

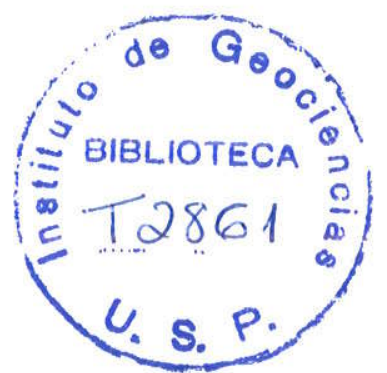

Nome

Assinatura

Presidente: $\quad$ Prof $^{\mathrm{a}} \mathrm{Dr}^{\mathrm{a}}$ Annkarin Aurelia K. e Silva

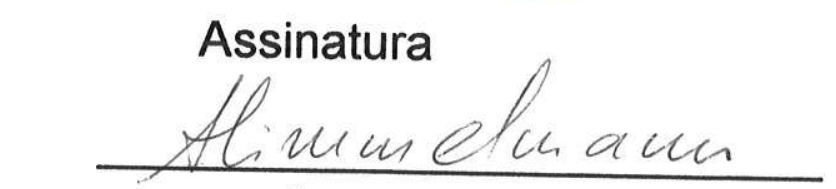

Examinadores: Prof. Dr. Aldo da Cunha Rebouças

Prof. Dr. Chang Hung Kiang

Prof. Dr. José Eloi Guimarães Campos

Prof. Dr. Luiz Roberto Cottas

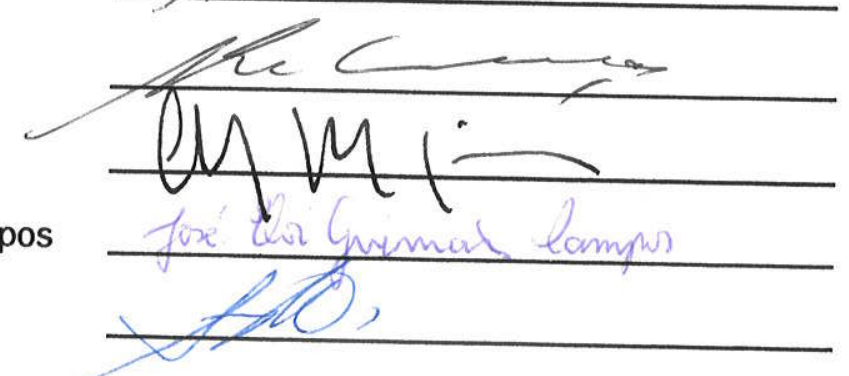

SÃO PAULO

2000 


\title{
UNIVERSIDADE DE SÃO PAULO INSTITUTO DE GEOCIÊNCIAS
}

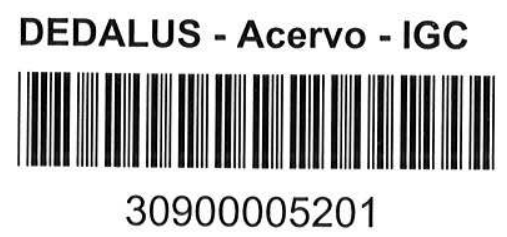

HIDROGEOLOGIA EM MEIO URBANO. REGIÃO DE CUIABÁ E VÁRZEA GRANDE - MT.

\author{
Renato Blat Migliorini
}

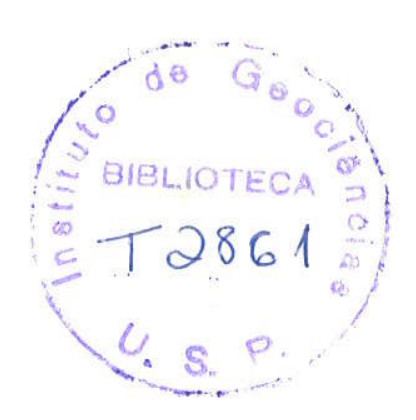

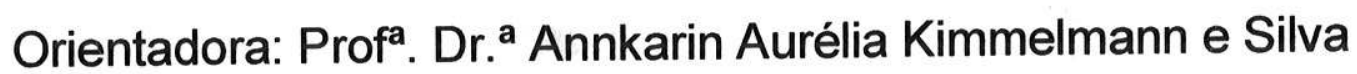

\section{TESE DE DOUTORAMENTO}

Ảrea de Concentração: Recursos Minerais e Hidrogeologia 
Aos meus pais, Emília e Renato, para registrar meu reconhecimento pelo apoio solidário em todos os momentos de minha vida.

A Anunciação, minha esposa, companheira presente em todos os momentos de nossa vida conjunta. 


\section{ÍNDICE}

Resumo

Abstract

1. Introdução

2. Objetivos

3. Area de Estudo

3.1. Localização e Vias de Acesso 22

3.2. Caracterização Físio-Climática e Vegetação 23

3.3. Disponibilidades Hídricas

4. Uso e Ocupação Atual do Solo 25

4.1. Introdução $\quad 25$

4.2. Metodologia $\quad 27$

4.3. Resultados $\quad 27$

5. Geologia 28

5.1 Revisão Bibliográfica dos Estudos Geológicos do Grupo Cuiabá 29

5.1.1. A Faixa de Dobramentos Paraguai 29

5.1.2. Histórico $\quad 29$

5.1.3. Arcabouço Geotectônico Regional 30

5.1.4. Domínio Tectônico Interno

5.1.5. Domínio Tectônico Externo

5.1.6. Coberturas de Antepaís 36

5.1.7. O Grupo Cuiabá na Baixada Cuiabana 36

5.1.8. A Estratigrafia do Grupo Cuiabá $\quad 37$

5.1.9. O Grupo Cuiabá, Segundo o Projeto Coxipó 
5.1.10. O Grupo Cuiabá, Segundo Alvarenga (1.990) 38

5.1.11. A Geologia Estrutural do Grupo Cuiabá 40

5.2. Geologia Local 42

5.2.1. Introdução 42

5.2.2. Grupo Cuiabá 42

5.2.3. Formação Miguel Sutil 43

5.2.4. Formação Rio Coxipó 46

5.2.5. Geologia Estrutural $\quad 49$

5.2.6. A relação entre as litologias e as estruturas geológicas, com o controle das águas subterrâneas $\quad 59$

6. Balanço Hídrico 63

6.1. Introdução 63

6.2. Metodologia $\quad 64$

6.3. Resultados 66

7. Levantamento de Dados Sobre os Sistemas Produtores de Abastecimento e Saneamento da Área Estudada $\quad 70$

7.1. Situação do Sistema Produtor da Região de Cuiabá e Várzea Grande 70

7.2. Sistema de Abastecimento de Água em Cuiabá e Várzea Grande $\quad 74$

7.2.1. Captação e Distribuição de Agua $\quad 74$

7.2.2. Indice de Abastecimento de Água 76

$\begin{array}{ll}\text { 7.3. Sistema do Saneamento } & 78\end{array}$

7.4. Situação dos Efluentes Industriais $\quad 81$

7.5. Situação das Praias $\quad 84$

8. Poços Tubulares: estudo dos relatórios técnicos 85

8.1. Metodologia $\quad 85$

8.2. Resultados $\quad 87$

9. Qualidade Físico-Química e Bacteriológica das Águas Subterrâneas 102

9.1. Materiais e Métodos 102

9.2. Resultados 104 
10. Retomada e Discusão dos Principais Resultados

11. Modelo Hidrogeológico

12. Conclusões

13. Sugestões

14. Bibliografia

Fig. 01. Mapa de localização da área de estudo

Fig. 02. Distribuição das faixas de dobramentos brasilianas e seus respectivos antepaís. (Seg. Schobbenhaus Filho, 1.984)

Fig. 03. Faixa de Dobramentos Paraguai, sua extensão, unidades litoestratigráficas constituintes e geometria. (Seg. Almeida, 1.984)

Fig. 04. Faixa de Dobramentos Paraguai e suas zonas estruturais. (Seg. Alvarenga, 1.990)

Fig. 05. Seção Geológica "A". (Seg. Alvarenga \& Trompette, 1.993)

Fig. 06. Relações estratigráficas entre as unidades sedimentares que constituem a Faixa de Dobramentos Paraguai (Seg. Alvarenga, 1.990) 35

Fig. 07. Mapa geológico regional da Faixa Paraguai, (Seg. Alvarenga, 1.988) 39 
Fig. 09. Diagrama de freqüência das medidas da foliação $\$ 1$

Fig. 10. Diagrama de freqüência das medidas dos Veios de Quartzo

Fig. 11. Diagrama de freqüência das medidas da foliação $S 2$

Fig. 12. Diagrama de freqüência das medidas da clivagem $\$ 3$

Fig. 13. Captação de água superficial e subterrânea em Cuiabá

Fig. 14.Captação de água superficial e subterrânea em Várzea Grande

Fig. 15. Tipos de ligações para o abastecimento de água em Cuiabá

Fig. 16. Tipos de ligações para o abastecimento de água em Várzea Grande

Fig. 17. Distribuição de lixos e aterros sanitários de Cuiabá

Fig. 18. Distribuição de lixos e aterros sanitários de Várzea Grande

Fig. 19. Profundidade dos Poços

Fig. 20. Nivel Estático

Fig. 21. Nível Dinâmico

89

Fig. 22. Mapa Potenciométrico (chuva)

Fig. 23. Mapa Potenciométrico (seca)

Fig. 24. Rebaixamento 
Fig. 26. Capacidade Específica

Fig. 27. Transmissividade

Fig. 28. Aberturas das Fraturas 96

Fig. 29. Condutividade Hidráulica 97

Fig. 30. Permeabilidade

Fig. 31. Porosidade 98

Fig. 32. Mapa de Isovalores do Manto de Alteração 99

Fig. 33. Turbidez 105

Fig. 34. Cor 106

Fig. 35. Concentração Hidrogeniônica 107

Fig. 36. Alcalinidade de Bicarbonato 108

Fig. 37. Alcalinidade de Hidróxido 108

Fig. 38. Alcalinidade de Carbonato 109

Fig. 39. Gás Carbônico 110

Fig. 40. Dureza Total

Fig. 41. Dureza Permanente

Fig. 42. Dureza Temporária 113 
Fig. 43. Nitrogênio Amoniacal

Fig. 44. Nitrogênio de Nitrito

Fig. 45. Fosfato

Fig. 46. Ferro

Fig. 47. Cálcio

Fig. 48. Cloretos

Fig. 49. Oxigênio Consumido

Fig. 50. Coliformes (total)

Fig. 51. Coliformes (fecal)

\section{Lista de Tabelas}

Tab. 01. Estratigrafia do Grupo Cuiabá, na área do Projeto Coxipó (Luz et alii, 1.980)

Tab. 02. Principais características das quatro fases de deformação, de idade brasiliana, identificadas na Faixa Paraguai (Alvarenga, 1.990)

Tab. 03. Temperatura Média Mensal 
Tab. 05. Balanço Hídrico

Tab. 06. Descargas Médias Mensais do Rio Cuiabá

Tab. 07. Produção de Água em Cuiabá

Tab. 08. Produção de Água em Várzea Grande

Tab. 09. Carga Orgânica de Origem Industrial em Cuiabá (Teixeira, 1.997)

Tab. 10. Carga Orgânica de Origem Industrial em Várzea Grande (Teixeira, 1.997)

Tab. 11. Parâmetros Estatísticos das Caracteristicas dos Poços

Tab. 12. Classificação de Produtividade de Aqüífero no Brasil (Mente \& Mont'Alverne, 1.982)

Tab. 13. Parâmetros Hidráulicos

Tab. 14. Qualidade da Água Subterrânea

\section{Lista de Fotos}

Foto 01.Filitos sericíticos da Formação Miguel Sutil, laminados de coloração cinza avermelhado, cortados por veios de quartzo sub-concordantes com a foliação e dobrados intensamente 
Foto 02. Seqüências granodecrescentes da Formação Miguel Sutil, dominadas por metaconglomerados oligomíticos na base e arenitos quartzosos e no topo metassiltito

Foto 03. Metadiamictitos da Formação Rio Coxipó, de coloração cinza amarelada, matriz argilosa maciça que sustenta os clastos de composição e tamanho diversos

Foto 04. Metadiamictitos da Formação Rio Coxipó, com matriz arenosa cortados por veios de quartzo oblíquos, intercalados a metarenitos quartzosos plano-paralelos

Foto 05. Dobras parasitas assimétricas desenvolvidas em intercalações de metarenitos quartzosos e filitos sericíticos da Formação Miguel Sutil

Foto 06. Metarenitos conglomeráticos quartzosos, recortados por veios de quartzo conjugados da Formação Miguel Sutil

Foto 07 . Metarenitos conglomeráticos quatzosos, cortados por veios de quartzo lenticulares da Formação Miguel Sutil

Foto 08 . Desenvolvimento de clivagem disjuntiva paralelas em metadiamictitos da Formaçăo Rio Coxipó 


\section{Anexos}

01. Mapa de Uso e Ocupação do Solo

02. Mapa Geológico

03. Mapa de Localização dos Poços Tubulares e dos Afloramentos

04. Banco de Dados dos Poços Tubulares 


\section{AGRADECIMENTOS}

A realização deste trabalho tornou-se possível devido ao valioso auxílio e colaboração de várias pessoas e entidades, às quais o autor externa seus sinceros agradecimentos.

À Prof.a Dr.a Annkarin Aurélia Kimmelmann e Silva pela orientação do trabalho.

Aos professores Aldo da Cunha Rebouças e José Milton Benetti Mendes pelas observações e sugestões pertinentes quando do Exame de Qualificação.

Ao colega Amarildo Salina Ruiz pela valiosa contribuição na realização do mapeamento geológico.

Ao professor João Manoel Filho pelo incentivo, sugestões e trocas de idéias.

Aos alunos da Universidade Federal de Mato Grosso: Aldiney Almeida Santos, Júlio Cesar Pinho Mattos e Fernando Martin Lopes pela colaboração no desenvolvimento do mapeamento geológico, nas análises físicomquímicas e bacteriológicas e nos trabalhos de computação, respectivamente.

Ao CNPq; à Pró-Reitoria de Pesquisa e Ensino de Pós-Graduação (PROPEP) da Universidade Federal de Mato Grosso e à Fundação de Amparo a Pesquisa do Estado de Mato Grosso (FAPEMAT) pelo apoio financeiro à pesquisa.

Ao Departamento de Geologia Econômica e Geofísica Aplicada do Instituto de Geociências da Universidade de São Paulo, ao Departamento de Geologia Geral e Departamento de Engenharia Sanitária e Ambiental, os dois últimos, da Universidade Federal de Mato Grosso, por fornecerem infra-estrutura, incentivo constante e ótimo ambiente de trabalho. 
As Firmas de Perfuração de Poços Tubulares de Mato Grosso (SANEMAT, GEOESTE, PROMOM, NOPAR E GEOSOLO), pelo fornecimento de relatórios técnicos dos poços tubulares indispensáveis à execução deste trabalho, estendendo agradecimentos aos colegas: Maurício Sant'ana Barros, João Batista Tolosa Neto, Wilce Aquino de Figueiredo, José Roberto Ribeiro, Adilson Valera Ruiz, Veríssimo Alves do Santos Neto, José Romualdo Morcelli e Marco Aurélio de Carvalho.

A todos que, de alguma maneira, contribuíram para a realização deste trabalho. 


\section{RESUMO}

Foram realizadas pesquisas hidrogeológicas nas regiōes metropolitanas de Cuiabá e Várzea Grande, coletadas informações e levantados dados importantes para análise da hidrogeologia da região. Os procedimentos adotados e os principais resultados obtidos podem ser resumidos como se segue.

Depois de uma detalhada revisão bibliográfica dos estudos sobre a geologia do Grupo Cuiabá, e dada a inexistência de trabalhos geológicos de detalhe e semidetalhe, necessários para um melhor conhecimento dos fatores condicionantes do armazenamento e fluxo das águas subterrâneas, realizamos um Mapeamento Geológico local na escala 1:25.000, visando especialmente à caracterização litológica e ao arranjo estrutural do substrato metamórfico de baixo grau, dos metassedimentos que compõem o Grupo Cuiabá. Pudemos individualizar duas formações geológicas que constituem nossa proposta para o Grupo Cuiabá na área estudada: a Formação Miguel Sutil e a Formação Rio Coxipó. O sistema aqüifero na região de Cuiabá e Várzea Grande é livre, heterogêneo e anisotrópico. A matriz rochosa é praticamente impermeável, sendo as fraturas e fissuras os condutos de movimentação mais fácil para as águas subterrâneas. As melhores condições aqüiferas encontram-se na litofácies argilo-areno-conglomerática da Formação Miguel Sutil e na litofácies metadiamictitos com matriz arenosa da Formação Rio Coxipó.

A partir da análise visual da imagem SPOT SX Bandas 1,2,3, área 2, na escala 1:40.000, de informações das atividades potencialmente poluidoras complementadas por trabalhos de campo, foi possivel elaborar um Mapa de Uso e Ocupação do Solo, com o enfoque voltado para as águas subterrâneas.

Utilizando dados de precipitação mensal, temperatura média mensal e anual, estimativas de evapotranspiração potencial e real para determinar a água armazenada no solo, excesso e deficiência hídrica, foi possível estimar o volume de recarga profunda para a região da Baixada Cuiabana. $O$ valor que encontramos: 
aproximadamente $1.603 .504 .000 \mathrm{~m}^{3} / \mathrm{ano}$, indica apenas uma ordem de grandeza e o método utilizado somente é valido para aqüiferos livres.

Com base em relatórios técnicos da Companhia de Saneamento do estado de Mato Grosso (SANEMAT) foi feito um levantamento de dados sobre a situação, em Cuiabá e Várzea Grande, do sistema produtor e do abastecimento de água, do saneamento, dos efluentes industriais e das condições sanitárias das praias. Observamos que:

1. O volume de água produzido pela SANEMAT, de certo modo, mostra-se satisfatório, porém apresenta um índice de perda muito elevado com média de $59,7 \%$ para Cuiabá e $63,7 \%$ para Várzea Grande.

2. Até 1.996 , os Municipios de Cuiabá e Várzea Grande ofereceram 158.834 ligações residenciais de água, abastecendo uma população de 686.545 habitantes, apresentando um índice geral de abastecimento em torno de $97,63 \%$.

3. As condições de saneamento básico de Cuiabá e Várzea Grande apresentam falhas, que favorecem a contaminação dos recursos hídricos superficiais e subterrâneos.

Foi cadastrada uma parcela significativa dos poços tubulares da região em um banco de dados e realizado, a partir dos relatórios técnicos, um estudo das características dos poços e do aqǘfero.

Foi realizado um estudo da qualidade físico-química e bacteriológica das água subterrâneas encontradas nos poços da região, tendo sido devidamente cadastrados os dados obtidos no banco de dados. Em geral as águas subterrâneas são de boa qualidade, com baixas concentrações dos principais parâmetros físico-químicos estudados, porém os parâmetros bacteriológicos (coli totais elou fecais), apresentam valores elevados, decorrentes de falhas no saneamento básico da região, aliadas a inadequadas técnicas construtivas dos poços tubulares e ao meio fraturado. Foram detectados também, alguns casos de concentração elevada de ferro, decorrentes da lixiviação do solo laterítico, característico do Grupo Cuiabá e pela presença de piritas disseminadas tanto nos filitos como nos metadiamictitos. 
Foram apresentadas algumas sugestões para a solução de problemas detectados.

Foi apresentado um Modelo Hidrogeológico para a região estudada. 


\section{ABSTRACT}

A hydrogeologic investigation was conducted in the metropolitan area of Cuiabá and Varzea Grande; related information and data important for the analysis of the hydrogeology of the area were also collected. The procedures used and the main results obtained can be summarized as follows:

After a careful review in the literature on the geology of the Cuiabá Group, and in view of the lack of detailed or semi-detailed geologic studies, essential for a better knowledge of the conditioning factors of storage and flow of groundwater, we have carried out a local geological mapping (scale 1:25000), for the lithologic characterization and the structural arrangement of the low- grade metamorphic metasediments which form the Cuiaba Group. This work made possible the identification of two geologic formations which constitute our proposal for the Cuiaba Group at the study area: the Miguel Sutil Formation and the Rio Coxipó Formation. The aquifer system at the Cuiaba and Varzea Grande area is unconfined, heterogeneous and anisotropic. The lithological units of the Cuiaba Group are practically impermeable. Thus fractures and fissures are the best conduits for the movement of groundwater. The best conditions for aquifers are present at the clay-sandstone-conglomerate lithofacies of the Miguel Sutil Formation and at the metadiamectites sandstones lithofacies of the Rio Coxipó Formation.

From the visual analysis of a satellite image (SPOT SX Bands 1,2,3, area 2, scale 1:40.000) and from data on potentially polluting activities, complemented with field work, it was possible to produce a Map of Land Use and Occupation, focussing on the ground water system.

On the basis of available data on monthly precipitation rates, monthly and annual average temperature, estimates of potential and real evapotranspiration to determine water stored in the soil, and water surplus and deficit, it was possible to estimate the recharge rate for the Baixada Cuiabana area. The calculation procedure used is valid only for unconfined aquifers, and the value found is approximately $1.610^{9} \mathrm{~m}^{3} /$ year, that indicates only an order of magnitude. 
Based on Companhia de Saneamento do Estado de Mato Grosso (SANEMAT) reports, a survey was developed in Cuiaba and Varzea Grande related to production and supply water systems, sanitation measures, industrial effluents and beach sanitary conditions, we found that:

1. The volume of water produced by SANEMAT is, to a certain extent, satisfactory, but the loss is too high, averaging $59.7 \%$ in Cuiaba and $63,7 \%$ in Varzea Grande;

2. Up to 1996, the counties of Cuiaba and Varzea Grande made water available to 158.834 residences, to attend a population of 686.545 dwellers, with an general supply index of around $97.63 \%$;

3. The basic sanitary conditions present deficiencies which causes the contamination of surface and underground water resources.

A significant part of the tubular wells in the area were catalogued and, on the basis of technical reports, the characteristics of the wells and of the aquifer were critically examined.

A study was made of the physicochemical and bacteriological qualities of ground water collected from wells in the area, and the obtained data were catalogued. Groundwater was found to be generally of good quality, with low concentration of the main physicochemical parameters investigated, but the bacteriological indices (total and/or fecal coliform) were unsatisfactory, as a consequence of the deficient basic sanitary conditions in the area, allied to the inadequate technique of tubular wells construction and to the fractured medium. In a few cases, high concentrations of iron were detected, produced by leaching of the lateritic soil, characteristic of the Cuiaba Group, and by the presence of pyrites disseminated both in philites and in metadiamectites.

From the results of the present work, suggestions to solve some of the problems encountered were made and a hydrogeologic model for the study area is presented. 


\section{INTRODUÇÃO}

Cuiabá foi fundada em 08 de abril de 1.719, mas somente em 1.818 a Vila Real do Senhor Bom Jesus de Cuiabá foi elevada à categoria de cidade sob a denominação de Cuiabá e através da Lei $N^{\circ} .19$ de 28 de agosto de 1.835 Cuiabá passa a ser a capital da Província. Já Várzea Grande foi emancipada através da Lei de 23 de Setembro de 1.948. (Teixeira, 1.997).

A cidade de Cuiabá surgiu em função da exploração mineral do ouro, no início do século XVIII. O Bandeirante Paschoal Moreira Cabral, ao aportar às margens do Rio Coxipó, em abril de 1.719 , à procura de indígenas para o trabalho escravo nas lavouras de São Paulo, encontrou ouro nos aluviões deste rio. A descoberta do ouro e o fácil acesso à região pela navegação fluvial, favoreceram o rápido crescimento do Arraial de Cuiabá. (Correa Filho, 1.993).

Desse modo, o crescimento populacional do Estado de Mato Grosso ocorreu a partir da utilização de recursos naturais. Predominou no início o extrativismo mineral, e posteriormente, o extrativismo vegetal. Atualmente, o Estado vem sofrendo um processo de ocupação sustentado, principalmente, pela agricultura e pela pecuária.

Enquanto Cuiabá abriga uma população de 433.355 habitantes, Várzea Grande abriga uma população de 193.401 habitantes, totalizando uma população de 626.756 pessoas na região estudada (IBGE, 1.996), que se localiza na região Centro-Oeste do país, no Estado de Mato Grosso.

Os municípios de Cuiabá e Várzea Grande apresentaram um grande crescimento econômico nos últimos anos. Este acelerado e desordenado crescimento econômico vem causando grandes dificuldades no tocante à quantidade e qualidade das águas para atendimento público e agro-industrial.

Se levarmos em conta, entre os problemas já verificados, a presença de poluição nas águas subterrâneas, de graves conseqüências para a saúde pública, é 
realmente surpreendente constatar que nenhum estudo hidrogeológico tenha sido realizado até o momento nestes municípios. O preenchimento desta lacuna foi a motivação principal deste trabalho, cujos objetivos são explicitados a seguir. 


\section{OBJETIVOS}

\section{Objetivo Geral:}

O trabalho teve como objetivo geral, proporcionar aos usuários de águas subterrâneas, com base nos dados obtidos na pesquisa, informações técnicas que os auxiliem na elaboração e desenvolvimento de seus projetos.

\section{Objetivos Específicos:}

Localizar as melhores condições aqüiferas do Grupo Cuiabá na região de Cuiabá e Várzea Grande, a partir de um Mapeamento Geológico na escala 1:25.000, visando especialmente a caracterização litológica e o arranjo estrutural;

Contribuir para o estudo das águas subterrâneas a partir da confecção de um Mapa de Uso e Ocupação do Solo com enfoque voltado para os recursos hídricos subterrâneos e uma estimativa do volume de recarga profunda para a regiảo;

Caracterizar a situação dos sistemas produtores de abastecimento e o saneamento básico da área estudada;

Estudar as características dos poços e do aqüífero, a partir dos relatórios técnicos dos poços tubulares;

Avaliar a qualidade físico-química e bacteriológica das águas subterrâneas encontradas nos poços tubulares. 


\section{3. ÁREA DE ESTUDO}

Nesta parte do trabalho apresentamos uma caracterização da região estudada. Serão abordados os seguintes aspectos: a localização e vias de acesso, uma caracterização físio-climática e disponibilidades hídricas de Cuiabá e Várzea Grande.

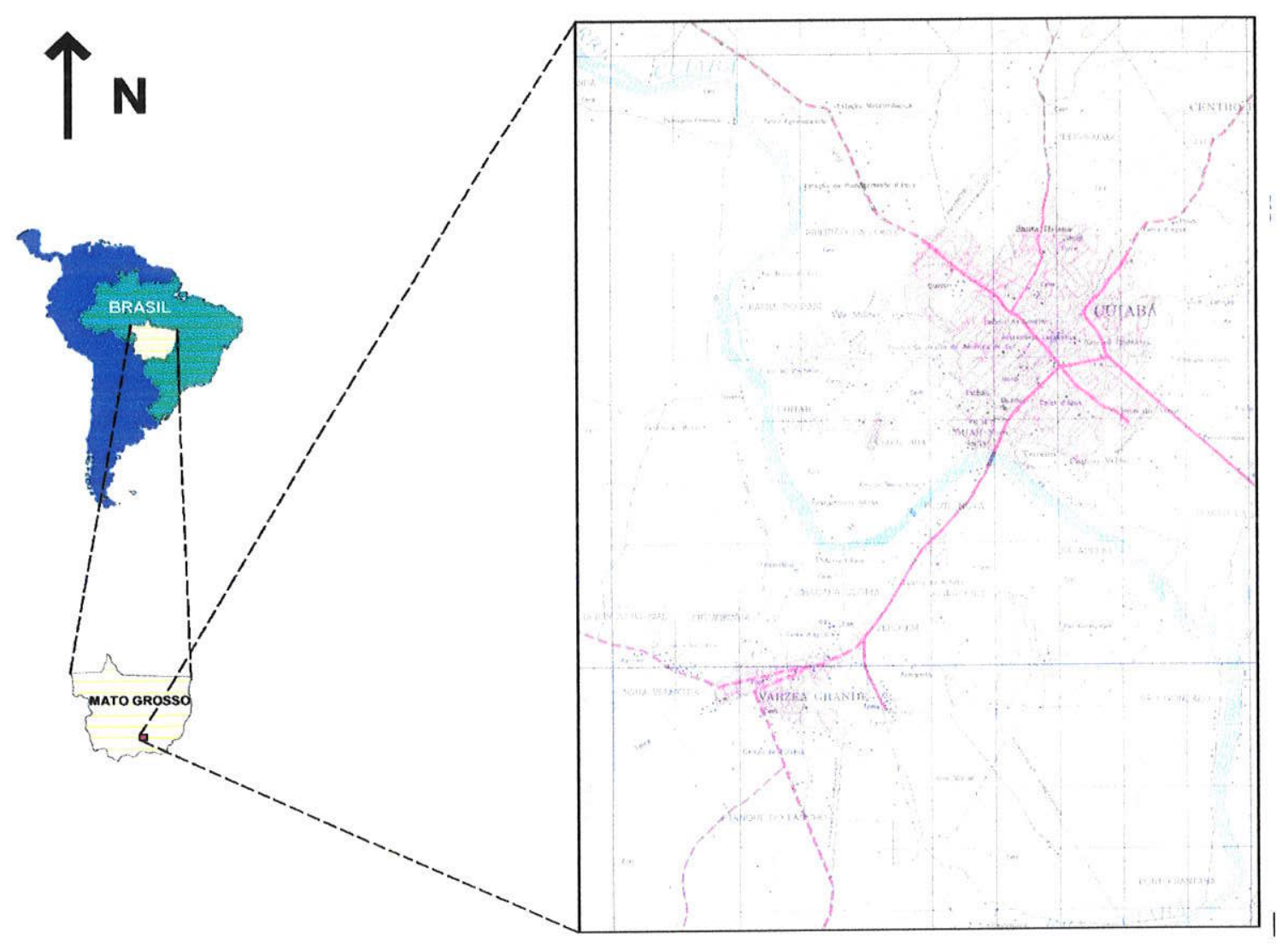

Figura 1. Mapa de Localização da Área de Estudo.

\subsection{Localização e Vias de Acesso}

As principais rodovias que dão acesso a região são: BR 163, BR 070, MT 040 e MT 060. 


\subsection{Caracterização Físio-Climática e Vegetação}

\section{Fisiografia}

Cuiabá e Várzea Grande situam-se na região Centro-Oeste do Brasil, tendo sido designada pelo Projeto Radambrasil (1.982) como Depressão Cuiabana. Compreende uma área rebaixada entre o Planalto dos Guimarães e a Província Serrana. Limita-se ao sul com o Pantanal Matogrossense, a oeste, noroeste e norte com a Província Serrana. Na seção leste seu limite encontra-se no Planalto dos Guimarães.

Do ponto de vista geomorfológico, a região possui a topografia rebaixada em torno de 150 a $200 \mathrm{~m}$ de altitude, sendo caracterizada por relevo de planície, desenvolvido sobre rochas Pré-Cambrianas fortemente deformadas.

\section{Clima}

O clima da região de Cuiabá e Várzea Grande está na categoria Aw da classificação de KÖPPEN, tropical semi-úmido (Galvão, 1.960).

Caracteriza-se por apresentar duas estações bem definidas: a seca que vai de abril a outubro, e a chuvosa que vai de novembro a março. A pluviometria média anual da regiâo oscila em torno de $1.350 \mathrm{~mm}$, com sazonalidade marcada por dois períodos bem distintos: no verão verifica-se os maiores índices pluviométricos, que oscila entre 1.000 e $1.500 \mathrm{~mm}$ e na estação seca a precipitação chega a ser quase nula. (Boletins Agroclimatológicos do Instituto Nacional de Meteorologia do Ministério da Agricultura, 1.996-1.997).

A evapotranspiração média real oscila em torno de $82 \mathrm{~mm}$ com valores de evapotranspirações mínimas entre 0 e $4 \mathrm{~mm}$ nos meses de julho a setembro e máximas em torno de $150 \mathrm{~mm}$, nos meses de novembro a março (Boletins Agroclimatológicos do Instituto Nacional de Meteorologia do Ministério da Agricultura, 1.996-1.997). 
A temperatura média anual é de $26^{\circ} \mathrm{C}$, com temperaturas mínimas próximas a $15^{\circ} \mathrm{C}$ em julho e máximas superiores a $32^{\circ} \mathrm{C}$, em outubro.

A umidade relativa do ar varia muito, com a média anual em torno de $74 \%$.

\section{Vegetação}

A divisão de vegetação do Projeto Radambrasil (1.982) considera a vegetação da área como pertencente à região fitoecológica da savana, correspondente ao que é regionalmente chamado de cerrado.

\subsection{Disponibilidades Hídricas}

A drenagem sofre um forte contorno estrutural. A área é recortada pelo Rio Cuiabá e seus principais afluentes que são os Rios Coxipó e Pari, além de várias drenagens de menor porte como Córrego São Gonçalo, Ribeirão Vermelho, Córrego Lavrinha, Córrego Figueirinha, Córrego Barbado, Córrego Três Barras, Córrego Mocinha, Córrego Quarta Feira, Córrego Ouro Fino, Córrego Mãe Bonifácia, Córrego Baú, Córrego Piçarrão, Córrego Traíra, Ribeirão Cocais, Córrego Formigueiro, Córrego Barbeiro, Córrego do Moinho, Rio Gambá, Rio Manuel Pinto, Ribeirão do Lipa e outros.

A vazão de alguns dos rios que drenam a região estudada, (Projeto de Recuperação e Conservação da Bacia do Rio Cuiabá, 1.996), é a seguinte:

- Ribeirão Cocais

- Córrego Formigueiro

- Córrego Barbeiro

- Córrego Lavrinha

- Córrego São Gonçalo

- Rio Coxipó

- Córrego do Moinho

- Córrego Três Barras

- Córrego Barbado

- Rio Gambá

- Rio Cuiabá

- Rio Manuel Pinto

- Ribeirão do Lipa

Vazão Total
$2,48 \mathrm{~m}^{3} / \mathrm{s}$

$2,43 \mathrm{~m}^{3} / \mathrm{s}$

$1,88 \mathrm{~m}^{3} / \mathrm{s}$

$0,88 \mathrm{~m}^{3} / \mathrm{s}$

$0,11 \mathrm{~m}^{3} / \mathrm{s}$

$5,75 \mathrm{~m}^{3} / \mathrm{s}$

$0,82 \mathrm{~m}^{3} / \mathrm{s}$

$0,14 \mathrm{~m}^{3} / \mathrm{s}$

$0,65 \mathrm{~m}^{3} / \mathrm{s}$

$0,15 \mathrm{~m}^{3} / \mathrm{s}$

$519 \mathrm{~m}^{3} / \mathrm{s}$

$0,34 \mathrm{~m}^{3} / \mathrm{s}$

$0,21 \mathrm{~m}^{3} / \mathrm{s}$

$534,84 \mathrm{~m}^{3} / \mathrm{s}$ 


\section{USO E OCUPAÇÃO DO SOLO}

\subsection{Introdução}

A primeira análise do uso e ocupação do solo na região de Cuiabá, foi realizada por Vecchiato (1.987), em Fotointerpretação Geológico-Geotécnica Aplicada ao Planejamento Urbano de Cuiabá e Várzea Grande - MT. O autor fez uma revisão de literatura dos Sistemas de Uso da Terra e Revestimento do Solo com o fim de fornecer informações gerais sobre a ocupação do solo na área considerada e elaborar uma "Carta de Uso e Revestimento do Solo".

Em 1.990, a Universidade Federal de Mato Grosso juntamente com a Prefeitura do município de Cuiabá elaboram a "Carta Geotécnica de Cuiabá", onde fazem uma análise de uso e ocupação do solo com enfoque aos problemas de geotecnia.

A terceira análise de uso e ocupação do solo na região de Cuiabá foi realizada, também, por Vecchiato (1.993) no trabalho Mapeamento Geotécnico da Area Urbana de CuiabámMT.

Uma quarta análise de uso e ocupação do solo, foi realizada por Maitelli (1.994) em "Uma Abordagem Tridimencional de Clima Urbano em Área Tropical Continental: $O$ Exemplo de Cuiabá-MT". Neste trabalho, o enfoque foi dado na investigação dos efeitos da urbanização na temperatura e umidade do ar na cidade de Cuiabá.

Como este trabalho tem como objetivo abordar a hidrogeologia da região de Cuiabá e Várzea Grande, a análise que faremos do uso e ocupação do solo terá como enfoque as águas subterrâneas.

Quando da elaboração deste capítulo, tornou-se necessário criar uma legenda específica que atendesse aos fins de um estudo hidrogeológico, uma vez que as legendas existentes, não satisfaziam os objetivos pretendidos. Assim, foi elaborada uma legenda própria, divididas em 5 itens e suas subdivisões descritas abaixo: 
1- Area construida

1.1-Densa

1.2- Escassa

2- Vegetação

2.1- Densa (de cerradão a matas ciliares)

2.2- Escassa (cerrados)

2.3- Agropecuária (pastagem natural de arbustos, pastagem plantada, pastagem mista; lavouras)

3- Areas degradadas por atividades de mineração (cavas de extração de areia, argila cascalho e, principalmente, garimpo de ouro).

\section{4- Atividades Poluidoras}

4.1- Indústrias potencialmente poluidoras.

Foram cadastradas neste item, as indústrias que possuiam lagoas de estabilização e/ou fossas sépticas que estavam cadastradas na Fundação Estadual do Meio Ambiente (FEMA). Indústrias de produção de óleo vegetal, usinas de asfalto, fábricas de refrigerante, indústrias de reciclagens de plásticos, fábricas de cerveja, frigorificos, fábricas de produtos de limpeza, curtumes, fábricas de tintas e vernizes, fábricas de ração, fábricas de produtos farmacêuticos, laticínios e fábricas de alimentos.

4.2- Armazenagem de combustível.

Foram cadastrados postos de comércio de combustivel (varejo e atacadista) e garagens de empresas transportadoras.

4.3. Cemitérios.

4.4. Rede de esgoto.

5- Atividades de Mineração

Foram cadastradas olarias, pedreiras, dragas de areia e extração de ouro. A extração de ouro hoje em dia, geralmente ocorre como subproduto das extrações de areia e cascalho. 


\subsection{Metodologia}

Os dados obtidos para a elaboração de Carta de Uso e Ocupação do Solo (vide anexo 04), foram realizados a partir da análise visual da imagem SPOT XS Bandas $1,2,3$, área 2, na escala 1:40.000, cedidas pela Fundação Estadual do Meio Ambiente (FEMA), de informações das atividades potencialmente poluidoras, também cedidas pela FEMA e complementadas por trabalhos de campo.

Durante a análise desta imagem foram observados os padrões de distribuição espacial, tamanho, cores, tonalidades e textura, para se detectar as diferentes formas de uso do solo. Os resultados obtidos foram ampliados para apresentação final na escala de 1:25.000.

\subsection{Resultados}

Os resultados deste estudo foram apresentados na carta "Uso e Ocupação do Solo na Região de Cuiabá e Várzea Grande,"(Anexo 01).

Pelo exame desta carta, verifica-se a tendência de ocupação urbana em Cuiabá, para direção nordeste, região do Centro Político Administrativo e na direção sudeste, ao longo da Rodovia Federal BR 364, região do Distrito Industrial de Cuiabá.

Verifica-se, também, que as áreas de solos expostos (áreas garimpadas, cavas de extração de areia e cascalho), são as que apresentam maiores evidências de processos erosivos.

Observa-se que a maior parte das cidades de Cuiabá e Várzea Grande, são desprovidas de rede de esgoto e que, alguns bairros, embora possuam rede de esgoto, não possuem estação de tratamento, sendo os efluentes despejados no rio mais próximo. 


\section{GEOLOGIA}

Nesta parte do trabalho apresentamos um quadro atualizado do conhecimento geológico do Grupo Cuiabá. Para alcançar essa meta, os temas abordados são tratados de maneira a ilustrar as várias etapas de aquisição das informações geológicas regionais.

Inicialmente apresentamos um breve histórico da evolução do pensamento geotectônico sobre a Faixa de Dobramentos Paraguai. Para caracterizar melhor a faixa de dobramentos, apresentamos o zoneamento estrutural proposto por Almeida em 1.984 e redefinido posteriormente por Alvarenga (1.990). Utilizamos as zonas estruturais individualizadas por aqueles autores, para apresentar as feiçōes estratigráficas, sedimentares, magmáticas e tectono-metamórficas que identificam essa província geotectônica.

A seguir apresentamos uma síntese sobre a geologia do Grupo Cuiabá, levandose em conta as suas relações de contatos, sua divisão em unidades estratigráficas, sua evolução tectônica e metamórfica e, finalmente, o magmatismo associado. Neste quadro sinóptico, ficaremos restritos à caracterização do Grupo Cuiabá, em suas exposições no domínio da Baixada Cuiabana.

Finalizando esta parte, apresentamos a geologia local, isto é, o Mapeamento Geológico que realizamos no Grupo Cuiabá nas regióes Metropolitanas de Cuiabá e Várzea Grande. 


\subsection{Revisão Bibliográfica dos Estudos Geológicos do Grupo Cuiabá}

\subsubsection{A Faixa de Dobramentos Paraguai}

\subsubsection{Histórico}

As primeiras observações e a constatação da existência de estruturas dobradas nas regiōes da Província Serrana e Baixada Cuiabana são devidas a Evans em 1.894.

Almeida (1.964) foi o primeiro a reconhecer essa faixa de dobramentos marginal ao Cráton, propondo a designação Geossinclíneo Paraguai para agrupar as três zonas estruturais que a compõe: a zona da Baixada do Alto Paraguai, da Província Serrana e Baixada Cuiabana.

Em 1.965, ao descrever a geotectônica do centro-oeste mato-grossense, Almeida a definiu como uma entidade tectônica brasiliana, que se estende em direção ao Baixo Tocantins e Araguaia, e utilizou pela primeira vez o termo Faixa de Dobramentos Paraguai-Araguaia.

Hasui e colaboradores (1.981), tendo como base os discordantes padrões geocronológicos e as fortes diferenças estruturais e de composição litológica apresentadas pelos segmentos Paraguai e Araguaia, sugerem, a individualização de duas faixas móveis marginais ao cráton Amazônico: a leste, a Faixa de Dobramentos Araguaia e a sudeste, nos estados de MT, MS e no Paraguai, a Faixa de Dobramentos Paraguai.

Almeida (1.984) faz uma sintese completa sobre essa unidade geotectônica e, apesar de abordar apenas o segmento Paraguai, utiliza ainda a denominação Faixa Paraguai-Araguaia. Neste trabalho, que foi a mais importante síntese sobre a geologia do Cinturão Paraguai, o autor identificou três zonas estruturais adjacentes - as Brasilides Metamórficas, as Brasilides Não-metamórficas e as Coberturas Brasilianas que retratam uma clara polaridade metamórfica e estrutural em direção ao Cráton Amazônico. 
Del'Rey Silva (1.990), considerando os dados estruturais obtidos em uma análise estrutural detalhada, realizada em algumas áreas da região de Cuiabá, sugere, para a Faixa Paraguai, uma evolução tectônica controlada por cinturões de cavalgamento do tipo película delgada (thin-skinned), explicando através de back-thrusting, a vergência centripeta que caracteriza essa faixa móvel.

Alvarenga (1.990) e Alvarenga \& Trompette (1.993) estudando o Cinturão Paraguai nas regiőes de Cuiabá, Mirassol D'Oeste e Província Serrana, reafirmam o zoneamento estrutural definido por Almeida (1.984), utilizando as designaçöes: Zona Interna, Zona Externa e Coberturas Sedimentares de Plataforma.

\subsubsection{Arcabouço Geotectônico Regional}

- Cinturão de Dobramentos Paraguai evoluiu no Proterozóico Superior/Cambriano (Ciclo Brasiliano, de $800 \mathrm{Ma}$ a $560 \mathrm{Ma}$ ), às margens do Cráton Amazônico, entidade geotectônica estabilizada no Proterozóico Médio, ao término do Ciclo Sunsas/Aguapeí (em torno de $900 \mathrm{Ma}$ ). (Figura 2).

Geograficamente, a Faixa Móvel Paraguai estende-se do Paraguai aos Estados de Mato Grosso do Sul, Mato Grosso e Goiás, perfazendo um total superior a 1.500 $\mathrm{km}$, que se acha recoberto, em grande parte, por sedimentos das bacias do Paraná, Pantanal e do Araguaia (Figura 3).

De uma maneira genérica, podemos identificar as seguintes feições que caracterizam a Faixa de Dobramentos Paraguai: apresenta forma de um arco convexo para o cráton (NW) _ seu trend no Paraguai e MS é aproximadamente NS, na região da Baixada Cuiabana inflete para NE/SW e, em seu extremo setentrional, região do Rio das Mortes, assume a direção $E N$; deformação polifásica com nítida polaridade tectônica e metamórfica, vergência centrípeta, espesso pacote sedimentar, magmatismo limitado e restrito à zona interna e uma marcada zonação estrutural. 
A seguir passaremos a apresentar, com maiores detalhes, as feições diagnósticas do Cinturäo Paraguai. Com esse fim, faremos uso do zoneamento proposto por Almeida em 1.984 e 1.985, Alvarenga (1.990) e Alvarenga \& Trompette (1.993).

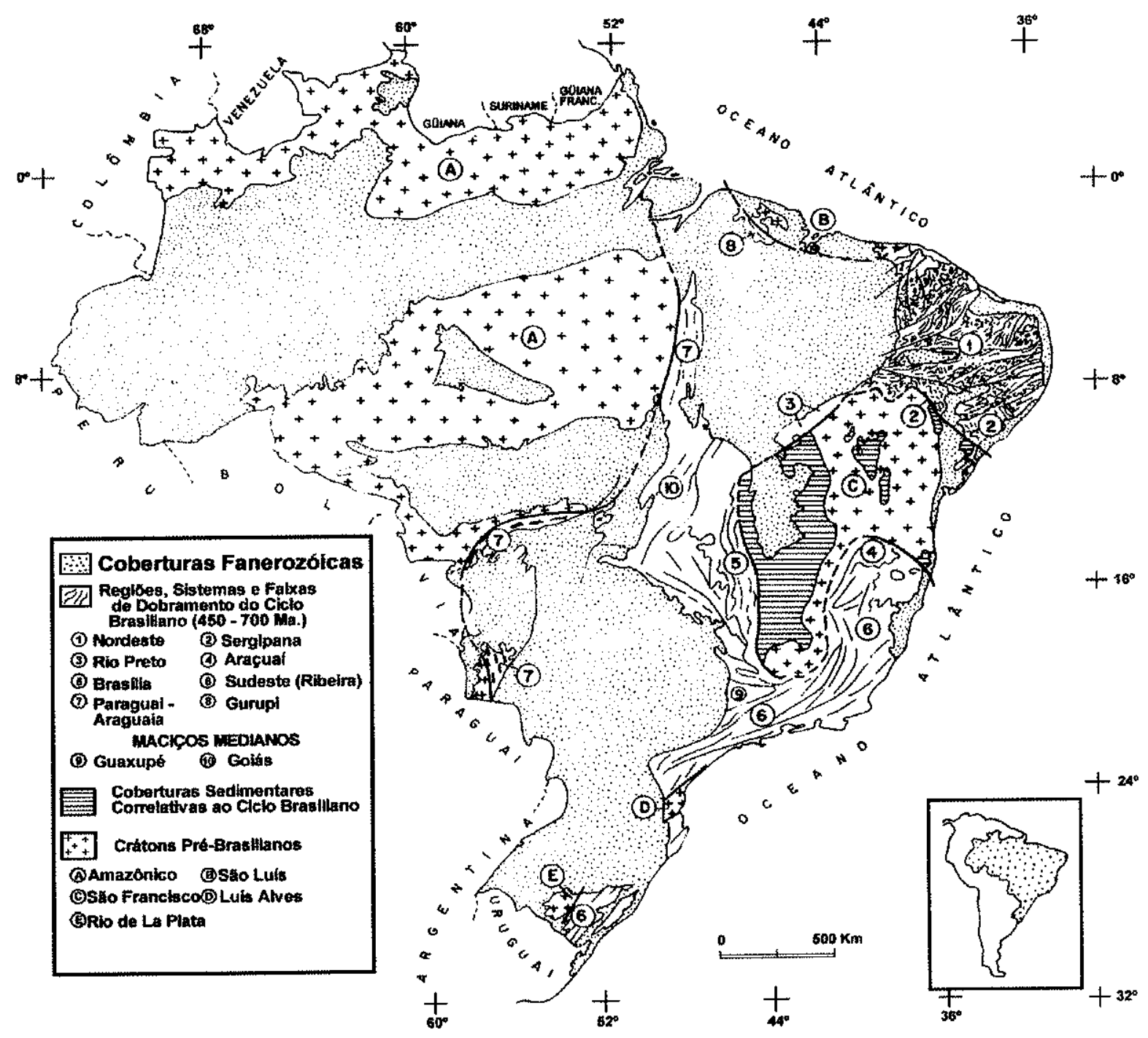

Figura 02. Distribuição das faixas de dobramentos brasilianas e seus respectivos antepais (Seg. Schobbenhaus Filho 1.984). 


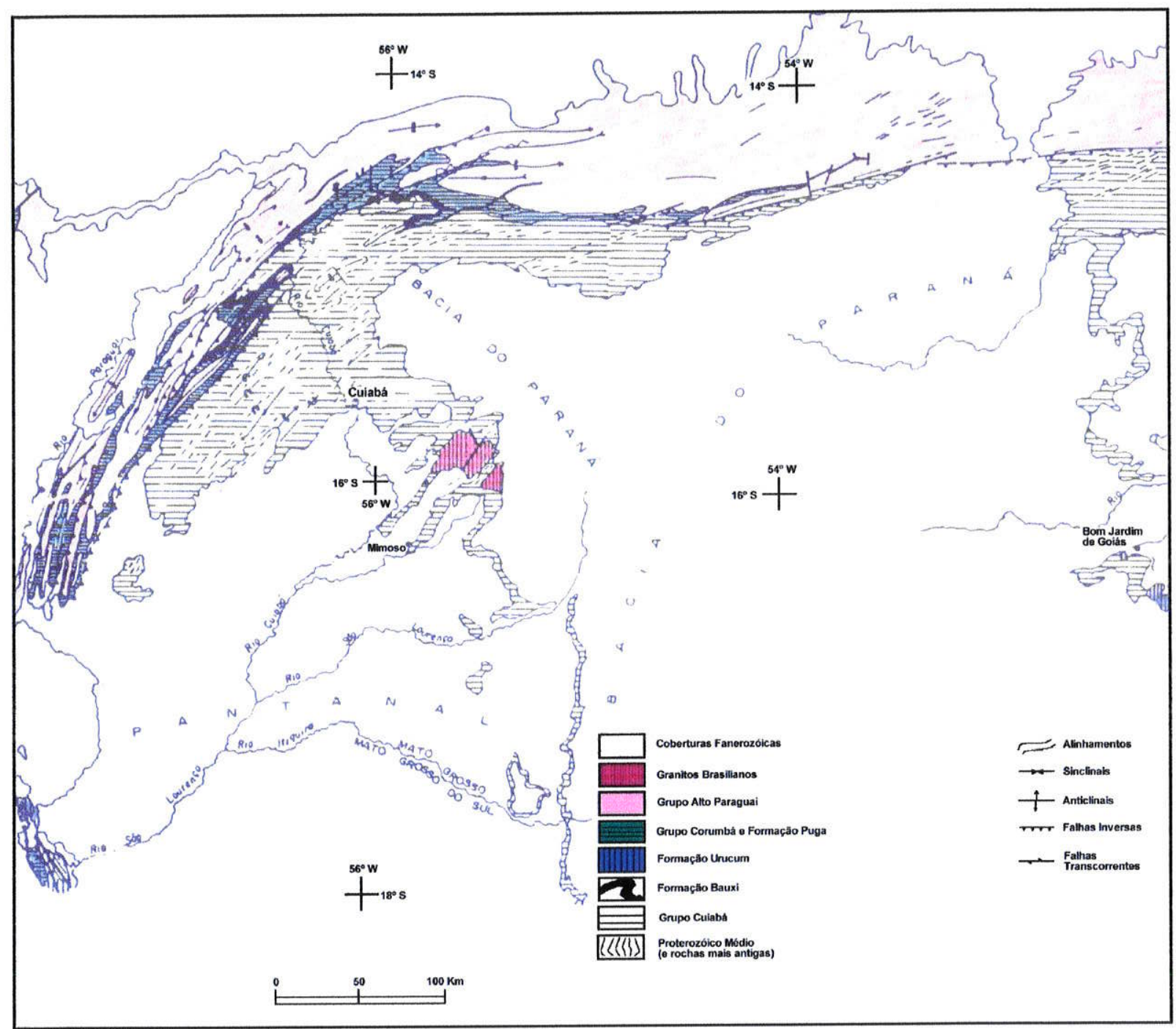

Figura 03. Faixa de Dobramentos Paraguai, sua extensão, unidades lítoestratigráficas constituintes e geometria (Seg. Almeida 1.984). 


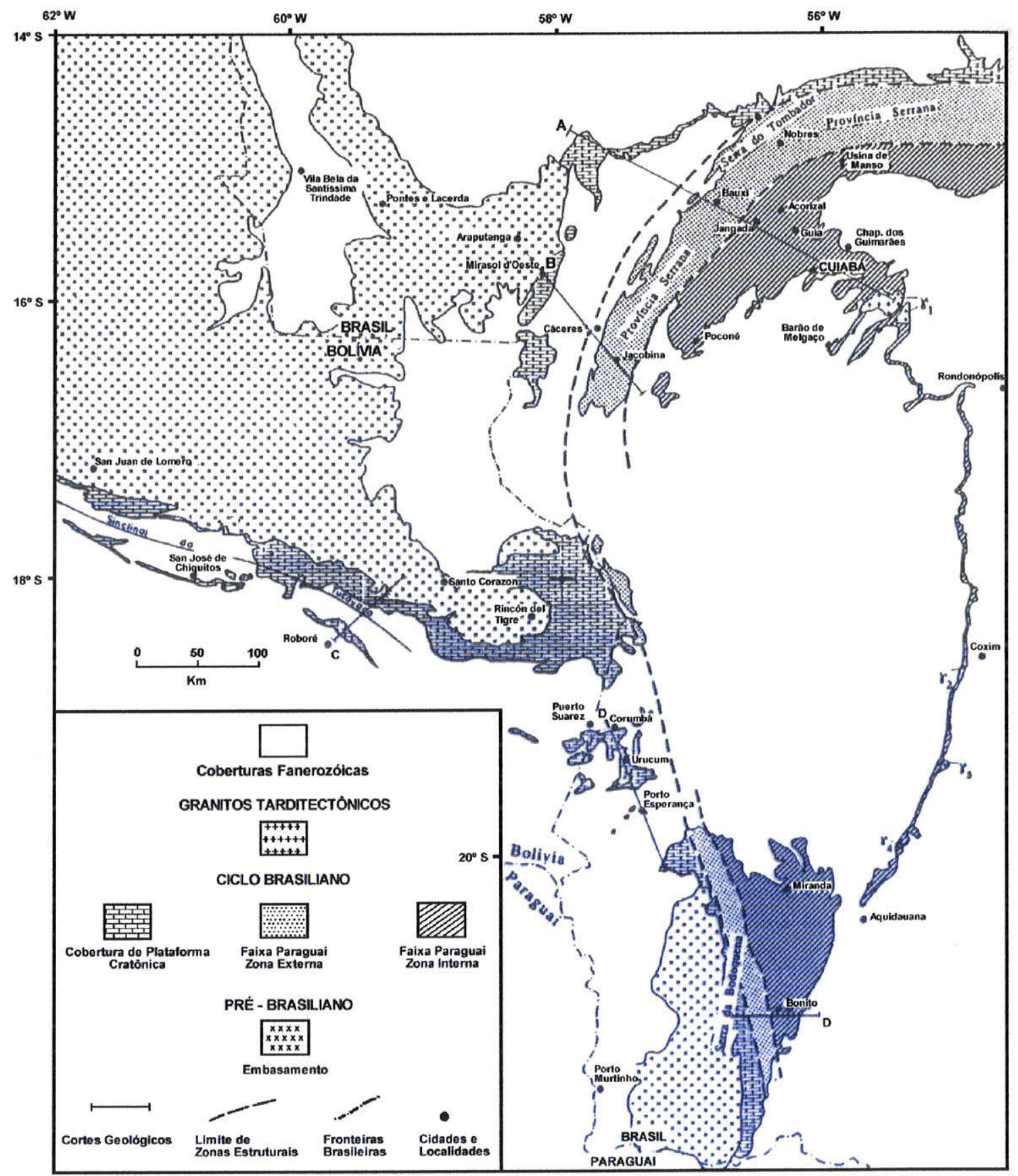

Figura 04. Faixa de Dobramentos Paraguai e suas zonas estruturais (Seg. Alvarenga 1.990) 


\subsubsection{Domínio Tectônico Interno}

A zona interna compreende as estruturas mais interiores da faixa e inclui as rochas mais antigas, o Grupo Cuiabá e as rochas intrusivas e extrusivas da região de Bom Jardim de Goiás. O metamorfismo regional é de baixo grau, fácies xisto verde, mostrando um incremento gradativo de noroeste para sudeste. A sua intensa deformação polifásica é caracterizada pelo registro de quatro fases de deformação progressivas - as três primeiras coaxiais, com trend nordeste, e a última ortogonal às demais. O magmatismo, relativamente escasso, está representado pelas ígneas cálcioalcalinas de Bom Jardim de Goiás e pelas rochas graníticas tardi-tectônicas de São Vicente, Coxim, Taboco e Rio Negro. Na figura 4 pode-se observar a área de domínio da zona interna e seus produtos magmáticos; nas seções geológicas apresentadas na figura 5, ilustramos o arranjo estrutural da zona em questão.

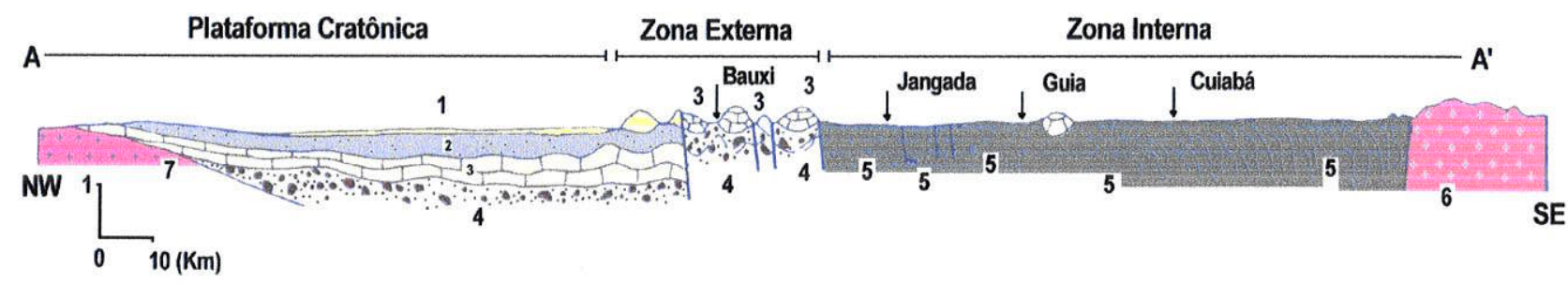

Figura 05. Seção geológica A---A' assinalada no mapa da figura 3: (1) Formação Pantanal, (2) Grupo Alto Paraguai, (3) Formação Araras, (4) Formação Puga e Bauxi, (5) Grupo Cuiabá, (6) Granito São Vicente e (7) Complexo Xingu (Seg. Alvarenga \& Trompette, 1.993).

\subsubsection{Domínio Tectônico Externo}

Almeida (1.984), descreve as seguintes feições características para essa zona estrutural: intensos dobramentos lineares margeando o limite cratônico, os eixos das dobras acompanham, em orientação, a forma convexa do cráton, falhamentos inversos ou de empurrão com transporte dirigido para noroeste, metamorfismo ausente ou 
incipiente e ausência de magmatismo. Esse domínio estrutural é constituído por uma espessa seqüência sedimentar, acumulada em uma bacia marinha pericratônica, possivelmente em uma margem continental passiva. Em termos litoestratigráficos, a zona externa é composta, da base para o topo, pelas Formações Bauxi, Puga, Araras e Grupo Alto Paraguai - Formações Raizama e Diamantino. A coluna estratigráfica ilustrada na figura 6 , mostra a seqüência de deposição regional e a possível relação dessas unidades com o Grupo Cuiabá. A tipologia dos dobramentos e o relacionamento tectônico com a zona interna são visualizadas nas seções geológicas apresentadas na figura 4 . Note 0 front tectônico que justapõe as duas zonas lateralmente e a gradação dos dobramentos da zona externa para a condição de coberturas plataformais sobre o Cráton Amazônico.

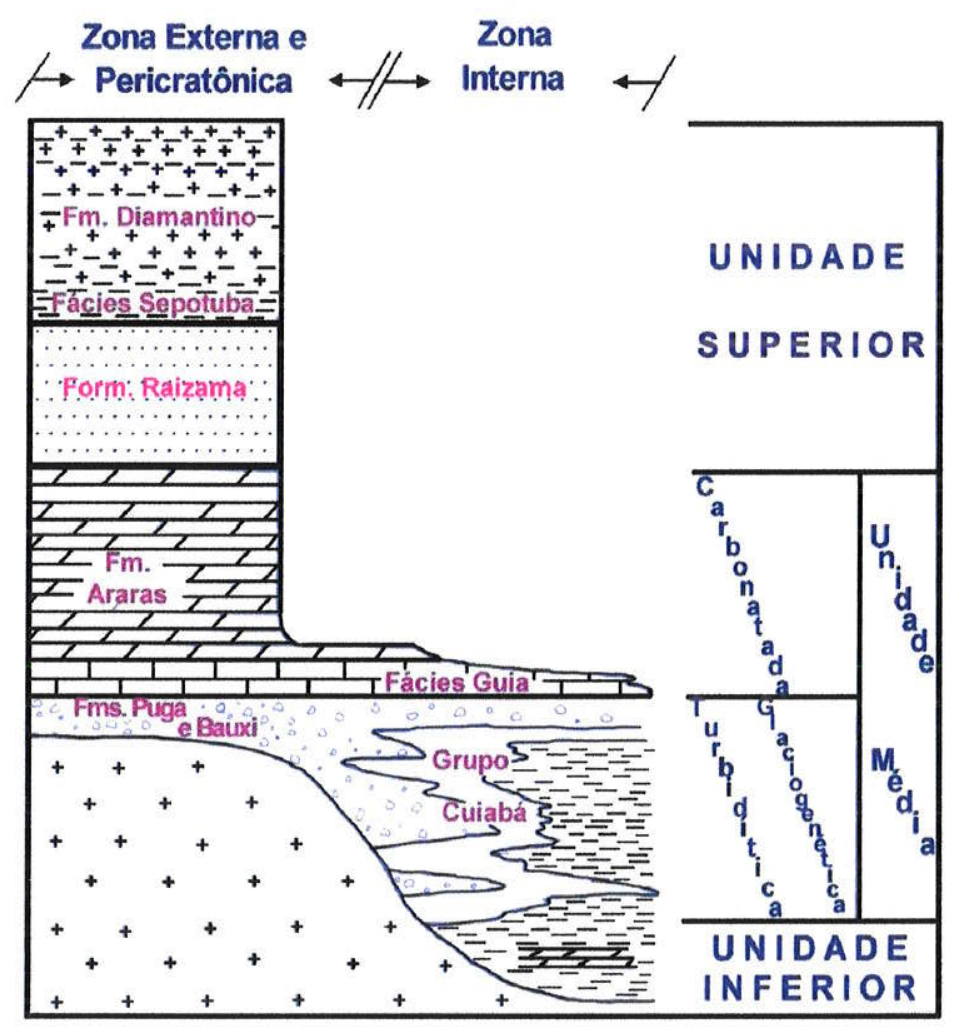

Figura 06. Relações estratigráficas entre as unidades sedimentares que constituem a Faixa de Dobramento Paraguai (Seg. Alvarenga 1.990). 


\subsubsection{Coberturas de Antepais}

As unidades litoestratigráficas que compõem a zona externa, Formações Bauxi, Puga, Araras e Grupo Alto Paraguai, passam gradativamente, em direção ao antepaís, à condição de coberturas plataformais suavemente onduladas e falhadas, mas sem a linearidade típica da faixa móvel. Até o presente, não há registros, em território brasileiro, de qualquer atividade ígnea nesta zona estrutural (Figura 3). Excetuando-se - Grupo Alto Paraguai, as demais formações expõem-se em áreas relativamente pequenas no Brasil e Paraguai; enquanto na Bolívia, elas alcançam até aproximadamente $500 \mathrm{~km}$ em direção ao interior do cráton.

\subsubsection{O Grupo Cuiabá na Baixada Cuiabana}

O Grupo Cuiabá se caracteriza por uma seqüência predominantemente de filitos com intercalações de quartzitos, metagrauvacas, metarenitos, metaparaconglomerados, com raras ocorrências de metacalcários e filitos calcíferos.

Coube a Evans em 1.894, a primeira descrição dessas rochas sob o nome de Cuyaba Slates; entretanto, a individualização como unidade litoestratigráfica, se deve a Almeida, que em 1.964, individualizou os Grupos Jangada e Cuiabá.

Na década de setenta, o DNPM e a CPRM realizaram inúmeros trabalhos de mapeamentos geológicos sistemáticos, em regiões onde o Grupo Cuiabá se apresentava. No entanto, nenhuma subdivisão foi proposta para o referido grupo, que continuou indivisivel.

Coube a Luz et al (1.980) e Souza (1.981), baseados nos resultados dos mapeamentos geológicos nas escalas 1:50.000 e 1:250.000 do Projeto Coxipó, individualizar oito sub-unidades litoestratigráficas para o Grupo Cuiabá.

Alvarenga em 1.990, em seu trabalho de tese que envolveu a geologia do Grupo Cuiabá na região da Baixada Cuiabana, dividiu esse grupo, utilizando critérios faciológicos, em uma unidade inferior e outra glaciomarinha e turbidítica. 


\subsubsection{A Estratigrafia do Grupo Cuiabá}

Quando se aborda esse tema, duas contribuições importantes devem necessariamente ser apresentadas; a de Luz et al (1.980) e a de Alvarenga (1.990). Dessa maneira, descreveremos primeiramente, a proposta de subdivisão estratigráfica do Projeto Coxipó e, em seguida, a proposição de Alvarenga.

\subsubsection{O Grupo Cuiabá, Segundo o Projeto Coxipó}

O resultado da cartografia geológica sistemática realizada pela equipe conduzida por Luz et al (1.980), é sem dúvida, a mais detalhada subdivisão estratigráfica definida para o Grupo Cuiabá. Os autores, conseguiram identificar oito sub-unidades passíveis de serem mapeadas na escala 1:50.000, e que apresentam feições geológicas bastante distintivas. Na tabela 1, apresentamos a coluna estratigráfica proposta pelo Projeto Coxipó e a constituição litológica típica de cada subunidade. 
Tabela 01. Estratigrafia do Grupo Cuiabá, na área do Projeto Coxipó (Luz et al, 1.980).

\begin{tabular}{|c|c|c|c|c|}
\hline \multicolumn{5}{|c|}{ ESTRATIGRAFIA PARA O GRUPO CUIABA, NA ÁREA DO PROJETO COXIPO } \\
\hline \multirow{3}{*}{$\begin{array}{l}\mathbf{P} \\
\mathbf{R} \\
\mathbf{E}\end{array}$} & \multirow{4}{*}{$\begin{array}{l}\mathbf{G} \\
\mathbf{R} \\
\mathbf{U} \\
\mathbf{P} \\
\mathbf{O}\end{array}$} & $\begin{array}{c}\text { Sub } \\
\text { Unidades }\end{array}$ & Litologias & $\begin{array}{l}\text { Espessura } \\
\text { (m) }\end{array}$ \\
\hline & & 8 & $\begin{array}{l}\text { Mármores calcíticos e dolomíticos, margas e filitos } \\
\text { sericíticos }\end{array}$ & 60 \\
\hline & & 7 & $\begin{array}{l}\text { Metaparaconglomerados petromíticos, com matriz areno- } \\
\text { argilosa e clastos de quartzo, quartzitos, feldspato, } \\
\text { calcário, rochas graníticas e básicas com raras } \\
\text { intercalações de filitos. }\end{array}$ & 600 \\
\hline \multirow{6}{*}{$\begin{array}{l}\text { C } \\
\mathbf{A} \\
\mathbf{M} \\
\mathbf{B} \\
\mathbf{R} \\
\mathbf{I} \\
\mathbf{A} \\
\mathbf{N} \\
\mathbf{0}\end{array}$} & & 6 & $\begin{array}{l}\text { Filitos conglomeráticos com matriz areno-argilosa e } \\
\text { clastos de quartzitos e filitos, com intercalações } \\
\text { subordinadas de metarenitos. }\end{array}$ & 800 \\
\hline & \multirow{5}{*}{$\begin{array}{c}\mathbf{C} \\
\mathbf{U} \\
\mathbf{I} \\
\mathbf{A} \\
\mathbf{B} \\
\dot{A}\end{array}$} & 5 & $\begin{array}{l}\text { Filitos e filitos sericíticos com intercalações subordinadas } \\
\text { e lentes de metarenito, metarcósios, quartzitos e } \\
\text { metaconglomerados. }\end{array}$ & 350 \\
\hline & & 4 & $\begin{array}{l}\text { Metaparaconglomerados petromíticos com matriz silte- } \\
\text { arenosa e clastos de quartzo, feldspato, quartzito, rochas } \\
\text { graníticas e básicas com raras intercalaçőes de filitos e } \\
\text { metarenitos. }\end{array}$ & 150 \\
\hline & & 3 & $\begin{array}{l}\text { Filitos, filitos conglomeráticos, metaconglomerados, } \\
\text { metarcósios, metarenitos, lentes de metacalcário, além } \\
\text { de níveis de hematita no topo }\end{array}$ & 550 \\
\hline & & 2 & $\begin{array}{l}\text { Metarenitos arcosianos, metarenitos calciferos, } \\
\text { metarcósios, filitos grafitosos e lentes de mármores } \\
\text { calcíferos. }\end{array}$ & 350 \\
\hline & & 1 & $\begin{array}{l}\text { Filitos sericíticos cinza-claro com intercalações de } \\
\text { metarenitos grafitosos. }\end{array}$ & 300 \\
\hline
\end{tabular}

\subsubsection{O Grupo Cuiabá, Segundo Alvarenga (1.990)}

Alvarenga (1.990), reuniu as rochas da Faixa Paraguai em quatro grandes grupos, formados por diferentes fácies: unidade inferior, de caráter local e situada no núcleo da Anticlinal de Bento Gomes; unidade glácio-marinha turbidítica formada durante a última glaciação brasiliana; unidade carbonatada e unidade superior detrítica. A figura 06 ilustra as relações estratigráficas entre essas unidades e o mapa geológico (figura 07), mostra as áreas de exposição das mesmas. 


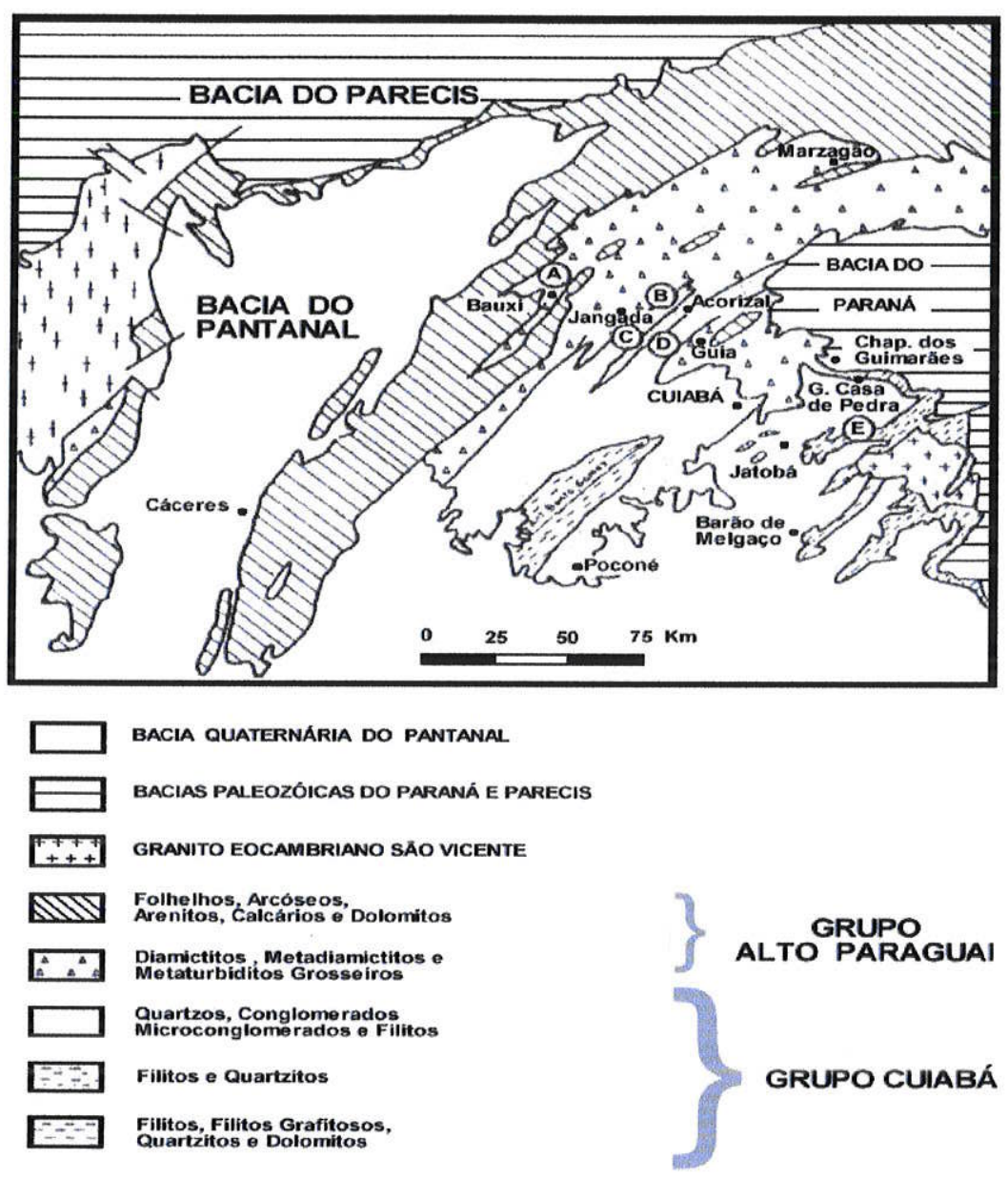

Figura 07. Mapa geológico regional da Faixa Paraguai, com as unidades estrátigráficas definidas por Alvarenga 1.988, 1.990. (Seg. Alvarenga 1988).

O Grupo Cuiabá, nesta proposta de divisão estratigráfica, é composto apenas pela unidade inferior e pela unidade glácio-marinha/turbidítica, as quais descrevemos a seguir:

Unidade Inferior. Esta unidade está representada apenas por parte do Grupo Cuiabá, situada no núcleo da Anticlinal de Bento Gomes, a noroeste de Poconé. A constituição litológica dessa unidade é dominada por filitos, filitos grafitosos, quartzitos e dolomitos. 
Esta associação corresponde às sub-unidades 1 e 2 do Projeto Coxipó. Verifique na tabela 01 a área de ocorrência da unidade inferior, restrita ao núcleo da anticlinal.

Unidade glácio-marinha-turbidítica. Inclui as rochas formadas durante o período glacial do Proterozóico Superior, inclusive as rochas formadas pela influência direta de uma sedimentação glácio-marinha e também as formadas em ambiente marinho mais distal, pelo retrabalhamento de materiais glaciogênicos por correntes de turbidez.

Três grandes grupos de fácies sedimentares, com base nas características de sedimentação turbidítica proximal, intermediária e distal, configuram a sedimentação no talude da bacia.

$\mathrm{Na}$ parte superior do talude, fácies proximal, são mapeados diamictitos intercalados a conglomerados e arenitos. Este conjunto corresponde às subunidades 4,5 e 7 descritas no Projeto Coxipó.

Em direção às partes mais externas do talude (fácies intermediária), observão-se filitos com espessas intercalações quartzitos, quartzitos conglomeráticos e metaconglomerados, organizados em ciclos de granodecrescência para o topo. Essa associação foi interpretada por Alvarenga (1.985) como leques submarinos de uma fácies turbidítica grossa e eqüivalem a subunidade 3 e parte da 5 .

Em direção ao extremo leste da bacia, encontra-se a fácies distal da unidade, composta quase exclusivamente por filitos com intercalações de quartzitos e metassiltitos. Essa fácies é correlacionada ao que o Projeto Coxipó denomina Grupo Cuiabá indiviso.

\subsubsection{A Geologia Estrutural do Grupo Cuiabá}

Luz et al (1.980) e Alvarenga \& Trompette (1.993) definiram a evoluçăo deformacional do Grupo Cuiabá na região da Baixada Cuiabana. 
$\mathrm{Na}$ tabela abaixo estão evidenciadas as principais características de cada fase de dobramentos que afetou a Faixa Paraguai na Baixada Cuiabana.

Tabela 02. Principais características das quatro fases de deformação, de idade brasiliana, identificadas na Faixa Paraguai (Alvarenga, 1.990).

\begin{tabular}{|c|c|c|c|c|c|c|}
\hline $\begin{array}{c}\text { FASES DE } \\
\text { DEFORMAČÃO }\end{array}$ & \multicolumn{2}{|c|}{$\overline{\text { D1 }}$} & \multirow{2}{*}{$\begin{array}{c}\text { D2 } \\
\text { Zona interna }\end{array}$} & \multirow{2}{*}{\begin{tabular}{|c|} 
D3 \\
Zona interna \\
\end{tabular}} & \multicolumn{2}{|c|}{ D4 } \\
\hline $\begin{array}{l}\text { Domínio } \\
\text { Estrutural }\end{array}$ & $\begin{array}{c}\text { Zona } \\
\text { externa }\end{array}$ & Zona interna & & & $\begin{array}{c}\text { Zona } \\
\text { externa }\end{array}$ & $\begin{array}{c}\text { Zona } \\
\text { interna }\end{array}$ \\
\hline Dobra & $\begin{array}{c}\text { Dobras } \\
\text { abertas } \\
\text { simétricas a } \\
\text { assimétricas }\end{array}$ & $\begin{array}{c}\text { Dobras } \\
\text { abertas, } \\
\text { assimétricas } \\
\text { fechadas, } \\
\text { inversas ou } \\
\text { isoclinal }\end{array}$ & $\begin{array}{l}\text { Ausência de } \\
\text { dobras } \\
\text { claramente } \\
\text { associada }\end{array}$ & $\begin{array}{c}\text { Dobras abertas e } \\
\text { assimétricas }\end{array}$ & \multicolumn{2}{|c|}{$\begin{array}{l}\text { Dobras de amplo } \\
\text { comprimento de } \\
\text { onda, visiveis na } \\
\text { escala de mapa }\end{array}$} \\
\hline Clivagem & $\begin{array}{c}\text { Clivagem } \\
\text { incipiente de } \\
\text { caráter local }\end{array}$ & $\begin{array}{c}\text { Clivagem de } \\
\text { fluxo } \\
\text { penetrativa }\end{array}$ & $\begin{array}{c}\text { Clivagem de } \\
\text { crenulação } \\
\text { penetrativa e } \\
\text { localizada }\end{array}$ & $\begin{array}{c}\text { Clivagem de } \\
\text { crenulação } \\
\text { pouco marcada } \\
\text { ou kinks e } \\
\text { localizada }\end{array}$ & \multicolumn{2}{|c|}{$\begin{array}{l}\text { Ausência de } \\
\text { clivagem, mas } \\
\text { ocorre um forte } \\
\text { fraturamento de } \\
\text { plano axial D4 }\end{array}$} \\
\hline Metamorfismo & $\begin{array}{c}\text { Anquizonal } \\
\text { de caráter } \\
\text { local }\end{array}$ & \begin{tabular}{|c|} 
Cristalizaçã \\
$o$ \\
sintectônica \\
de \\
filossilicatos
\end{tabular} & $\begin{array}{c}\text { Recristalizaçã } \\
\text { o sintectônica } \\
\text { de } \\
\text { filossilicatos }\end{array}$ & $\begin{array}{c}\text { Recristalização } \\
\text { sintectônica e } \\
\text { incipiente }\end{array}$ & \multicolumn{2}{|c|}{$\begin{array}{l}\text { Ausência de } \\
\text { recristalização } \\
\text { sintectônica de } \\
\text { filossilicatos }\end{array}$} \\
\hline
\end{tabular}




\subsection{Geologia Local}

\subsubsection{Introdução}

Nesta etapa do trabalho elaboramos um mapa geológico na escala 1:25.000 (Anexo 2), da área urbana e periurbana das cidades de Cuiabá e Várzea Grande, compreendendo aproximadamente $584 \mathrm{Km}^{2}$. A complexidade geológica do terreno e a falta de trabalhos geológicos de detalhe ou semi-detalhe que permitissem uma melhor compreensão dos fatores condicionantes que atuam no armazenamento e fluxo das águas subterrâneas, exigiram a elaboração desta carta geológica, centrada especialmente na caracterização litológica e no arranjo estrutural do substrato metamórfico de baixo grau, dos metassedimentos que compõem o Grupo Cuiabá.

Sob o ponto de vista geotectônico a área mapeada situa-se no Domínio Tectônico Interno da Faixa de Dobramentos Paraguai, implantada às margens do Cráton Amazônico, durante o Ciclo Orogênico Brasiliano no Neoproterozóico (Almeida, 1.984). As principais contribuições ao avanço do conhecimento geológico desta porção da Faixa Paraguai, são representadas pelo mapeamento geológico na escala 1: 50.000 , realizada pelo Projeto Coxipó (Luz et al 1.980) e, os trabalhos de cunho regional desenvolvidos por Barros et al (1982), Almeida (1.984, 1.985), Alvarenga (1.990), Alvarenga e Trompette (1.993).

\subsubsection{Grupo Cuiabá}

Esta unidade litoestratigráfica, descrita inicialmente por Evans (1.984) como Cuyiaba Slates, constitui, juntamente com os granitóides do tipo São Vicente, o Domínio Tectônico Interno do Cinturão de Dobramentos Paraguai. Esta unidade, caracterizada como um expressivo conjunto metassedimentar, constituído por metarenitos, metargilitos, metadiamictitos, metarcósios, filitos sericíticos, filitos carbonosos, além de formações ferríferas, calcários e margas, apresenta-se universalmente metamorfisada na fácies xisto-verde (Luz et al 1.980). 
$\mathrm{Na}$ área pesquisada verificamos que o Grupo Cuiabá expõe-se sob a forma de uma anticlinal invertida com caimento para NE, definindo uma estruturação onde os contatos entre os diversos litotipos, as foliações plano axiais ao dobramentos e as falhas relacionadas às dobras, desenham uma orientação preferencialmente $\mathrm{N} 30^{\circ}$ $40^{\circ} \mathrm{E}$. (Anexo 2). A seguir, são descritas as litofácies, ou conjuntos litológicos, que correspondem a nossa proposta para o Grupo Cuiabá na área estudada:

\subsubsection{Formação Miguel Sutil}

Esta unidade corresponde a Subunidade 5 do Projeto Coxipó (Luz et al 1.980), aflora praticamente em toda a porção central e norte das cidades de Cuiabá e Várzea Grande, mais especificamente no núcleo da anticlinal invertida que descreve o arcabouço estrutural desta região (Vide Mapa Geológico, Anexo 2).

Com base nas estruturas sedimentares e na constituição litológica dominante, pudemos individualizar dois conjuntos faciológicos que correspondem às unidades de mapeamento representadas no mapa geológico da área (Anexo 2), e que, a seguir, descrevemos com mais detalhes.

\section{Litofácies Pelítica com Laminação Plano-paralela}

Corresponde a metargilitos ou filitos de cor cinza esverdeada a marrom avermelhada, normalmente sericíticos, são freqüentes as laminações plano-paralelas centimétricas a milimétricas, indicadoras de mudança na granulometria ou composição dos sedimentos (Foto 01). Os metapelitos maciços são mais raros e ocorrem intercalados aos níveis laminados. São comuns, intercalações de camadas tabulares de arenitos finos a médios, de cor branca com tons róseos, principalmente quartzosos, em contatos abruptos com os pelitos laminados ou maciços. A espessura máxima destes pacotes arenosos não ultrapassa os $20 \mathrm{~cm}$ e sua forma tabular, contínua e as estratificações plano paralelas sugerem uma mudança na intensidade do fluxo subaquoso em uma ampla área de abrangência. 


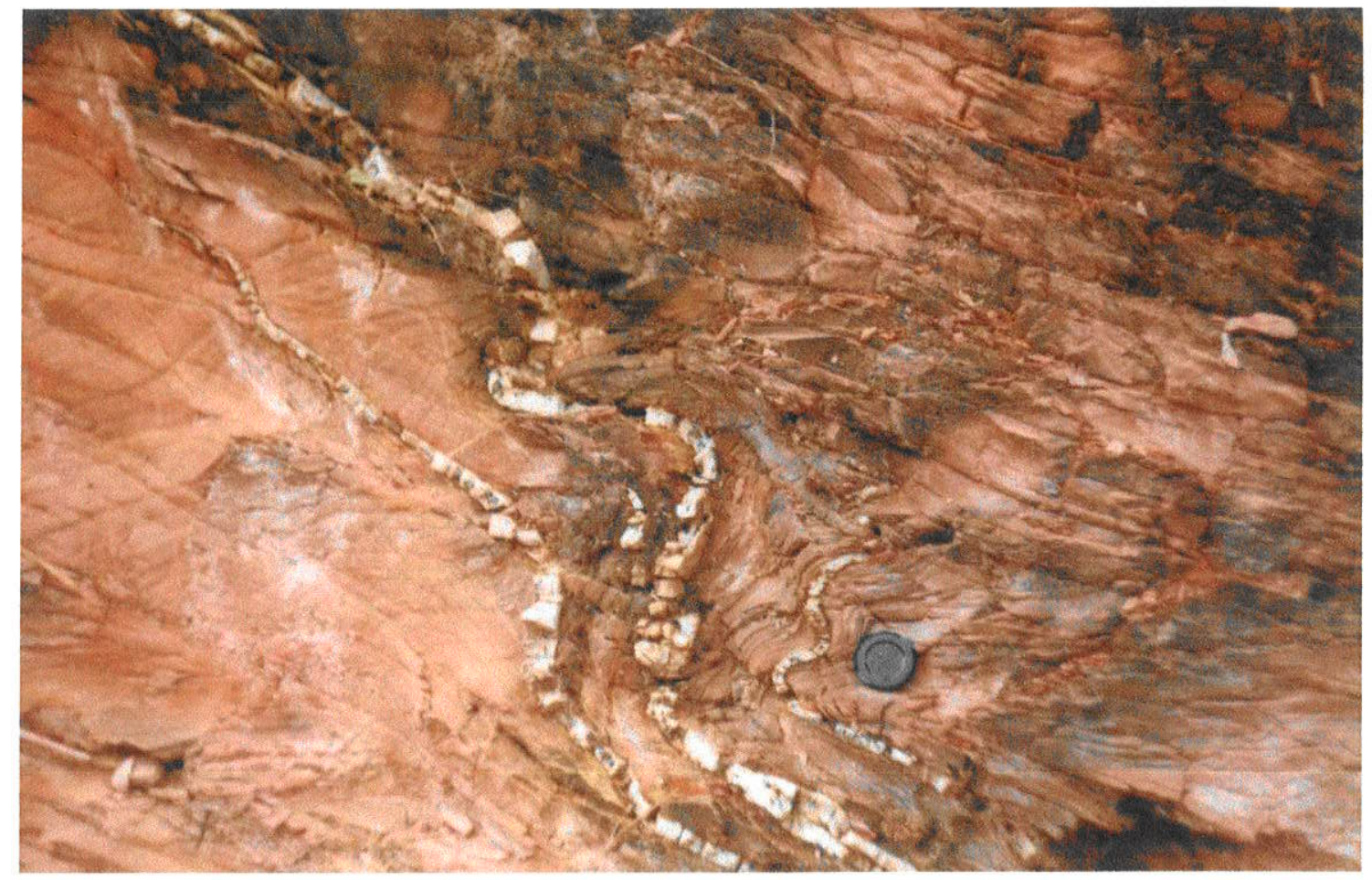

Foto 01.Filitos sericíticos da Formação Miguel Sutil, laminados de coloração cinza avermelhado, cortados por veios de quartzo sub-concordantes com a foliação e dobrados intensamente.

\section{Litofácies argilo-areno-conglomerática}

Esta unidade de mapeamento corresponde a seqüências cíclicas (ritmitos) granodecrescentes, que descrevem arranjos lenticulares principalmente segundo a direção $\mathrm{N} 30^{\circ}-40^{\circ} \mathrm{E}$. Este conjunto faciológico, formado por lentes métricas a quilométricas (Foto 02), faz contato do tipo abrupto e irregular com a litofácies pelítica, sendo comuns fragmentos de filitos desta, aparecerem com constituintes de seus níveis conglomeráticos basais. 


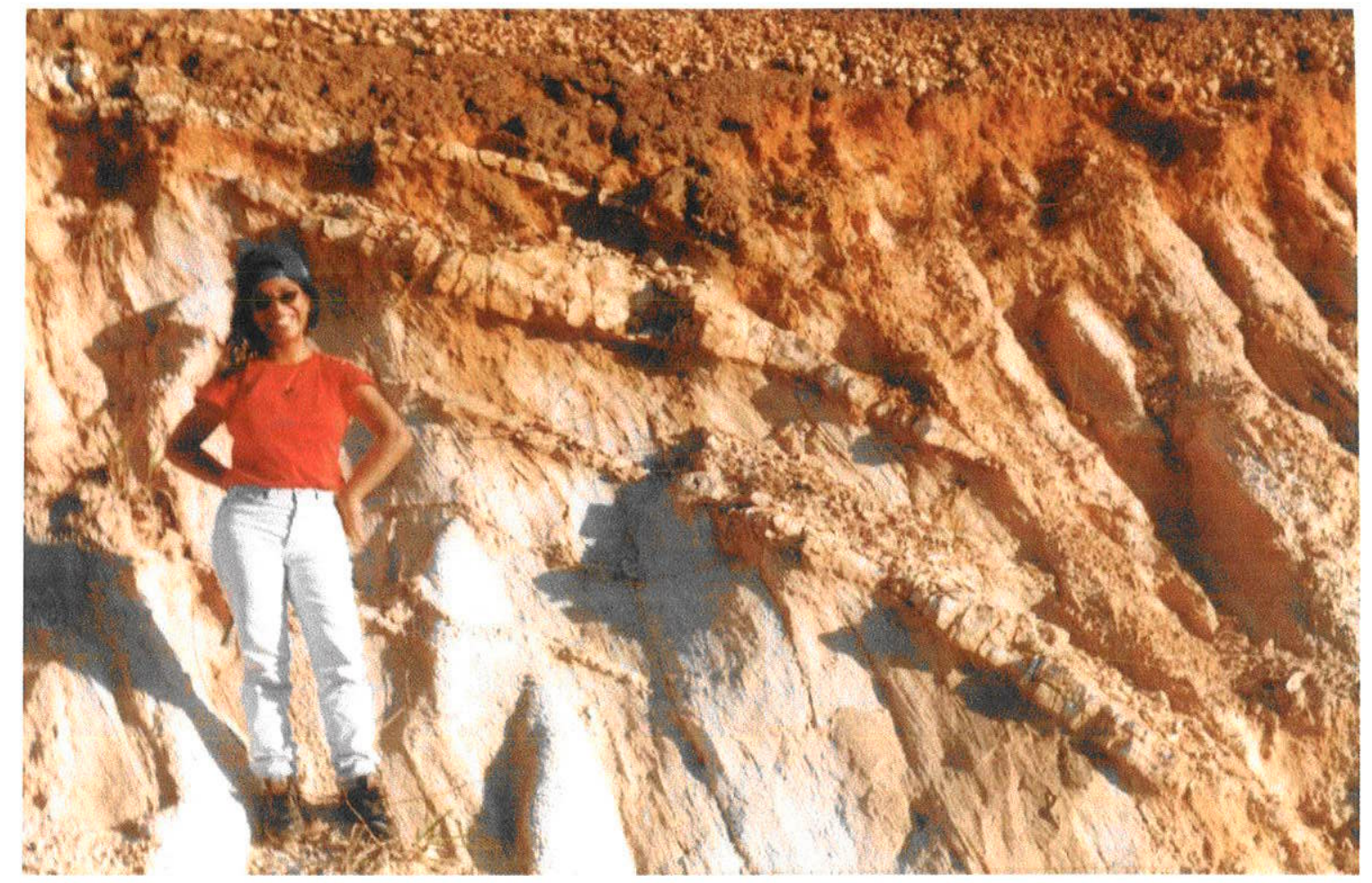

Foto 02. Seqüências granodecrescentes da Formação Miguel Sutil, dominadas por metaconglomerados oligomíticos na base e arenitos quartzosos e no topo metassiltitos.

Cada conjunto exposto desta litofácies constitui-se por seqüências cíclicas granodecrescentes, compostas na base, por metaconglomerados oligomíticos quartzosos, com seixos e grânulos dominados por quartzos leitosos levemente arredondados em uma matriz de areia grossa a microconglomerática, também quartzosa. Bandas finas e irregulares, de um material caulinítico, definem uma foliação principal nestas rochas, e sugerem a atuação de dissolução por pressão seguida pela neocristalização dos feldspatos ao longo dos planos de foliação.

$\mathrm{Na}$ porção intermediária de cada ciclo, dominam os arenitos quartzosos, algo feldspáticos, que gradam de areias grossas a médias até as porções de areia fina ou silte arenoso. 
As estratificações plano-paralelas são as estruturas reliquiares mais comuns, associadas, obviamente, a gradação normal decrescente. Em contato abrupto com a porção psamítica intermediária, completam o ciclo de ritmitos, os filitos sericíticos, laminados ou maciços, de cor cinza chumbo, cuja espessura não ultrapassa a 1 (um) metro.

Cada ciclo granodecrescente (conglomerado-arenito-argilito) apresenta espessura que varia entre 1 a 10 metros, e sua seção basal é definida por uma superficie irregular que sugere o processo de escavação e preenchimento, muito comuns às seqüências depositadas por correntes de turbidez em ambientes subaquosos. A estrutura interna de cada ciclo, em muitos casos, não apresenta a porção pelítica de topo, que pode ser o resultado da não deposição ou do processo de canibalismo das porções superiores de camadas mais antigas, pelos fluxos turbidíticos mais jovens. Esta possibilidade é reforçada pelo registro freqüente de intraclastos de filitos laminados e sericíticos, constituindo os conglomerados basais do ciclo turbidítico mais jovem.

\subsubsection{Formação Rio Coxipó}

Esta unidade, que corresponde a Subunidade 06 de Luz et al (1.980), sobrepõese à Formação Miguel Sutil através de contatos transicionais e tectônicos e aflora principalmente na porção sul das cidades de Cuiabá e Várzea Grande. Sob o ponto de vista do arranjo estrutural local, a sua exposição restringe-se ao flanco invertido da dobra anticlinal invertida com caimento para NE (Vide Mapa Geológico, Anexo 02).

O mapeamento sistemático permitiu a individualização de duas associações litológicas principais: a dos metadiamictitos com matriz argilosa, maciços, com raras intercalações de areia fina a média e dos metadiamictitos, com matriz arenosa, intercalados a arenitos quartzosos grossos e médios, que passamos a descrever em detalhe. 
Metadiamictitos com matriz argilosa.

Este conjunto litológico predomina em volume e área de exposição, mantém contato por falhas inversas ou transicionais com a Formação Miguel Sutil e corresponde a metadiamictitos maciços, cinza esverdeado a amarelados, com matriz argilo-siltosa, micácea, em parte feldspática, que suporta fragmentos centimétricos a métricos, de composição muito diversificada (granitos, xistos, quartzitos, anfibolitos, gnaisses, arenitos, filitos, quartzo, etc.) e formato prolato resultante do achatamento regional provocado pela deformação.

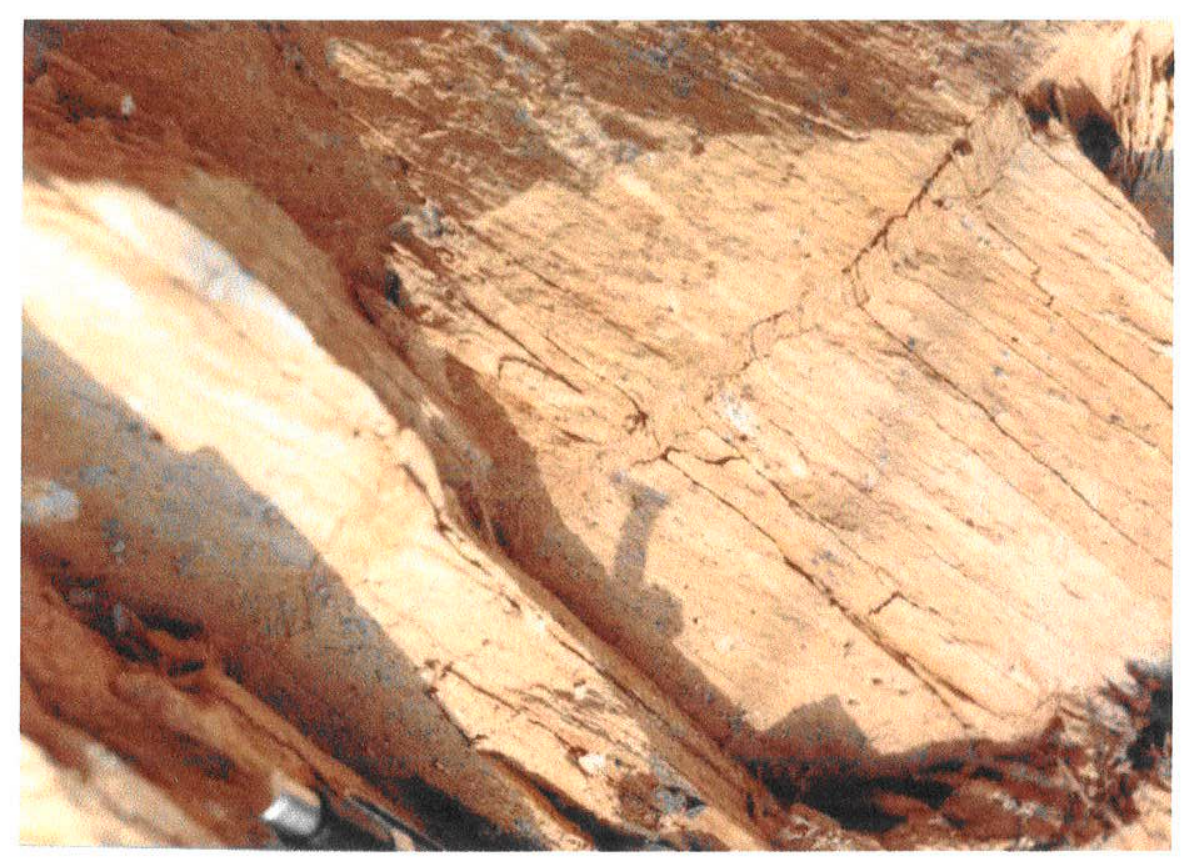

Foto 03. Metadiamictitos da Formação Rio Coxipó, de coloração cinza amarelada, matriz argilosa maciça que sustenta os clastos de composição e tamanho diversos.

Uma marcante fissilidade, conferida principalmente pela foliação penetrativa do tipo xistosidade, caracteriza esses diamictitos de matriz argilo-siltosa.

Camadas tabulares e lentes de metarenitos quartzosos de granulação fina a média, de cor cinza esbranquiçada, com estratificação plano-paralela e maciços, ocorrem intercaladas aos metadiamictitos. Suas ocorrências são mais raras e estreitas, 
de 1 a 3 metros, em direção a porção sudoeste da área mapeada e, tornam-se mais comuns e espessas, acima de 50 metros, nas imediações da zona periclinal da anticlinal, setor NE da área estudada, onde definem um relevo de cristas alongadas segundo a direção nordeste.

\section{Metadiamictitos com matriz arenosa}

Esta associação litológica, que expõe-se apenas em raros cortes de estrada, ocorre principalmente na região do Parque Industrial e no Pascoal Ramos, em Cuiabá. O espesso manto laterítico desenvolvido nessa região impede o afloramento destes litotipos, dificultando a descrição das suas principais características.

Correspondem às porções de topo da Formação Rio Coxipó, e a geometria deste depósito ainda não foi caracterizada, embora haja indicações que sugerem um formato lenticular. A sua composição é dominada pelos metadiamictitos maciços, de matriz arenosa e mais raramente silto-argilosa, com clastos em maior quantidade do que observado nos metadiamictitos de matriz argilosa, e com dimensão e composição mais variadas. A matriz caracteriza-se como uma areia grossa a média, principalmente, de composição quartzosa. Os arenitos ocorrem sob a forma de camadas tabulares, de espessura variando entre $10 \mathrm{~cm}$ a $3 \mathrm{~m}$, mostram contatos abruptos com os diamictitos, e são compostos preferencialmente por areias grossas a médias, quartzosas. 


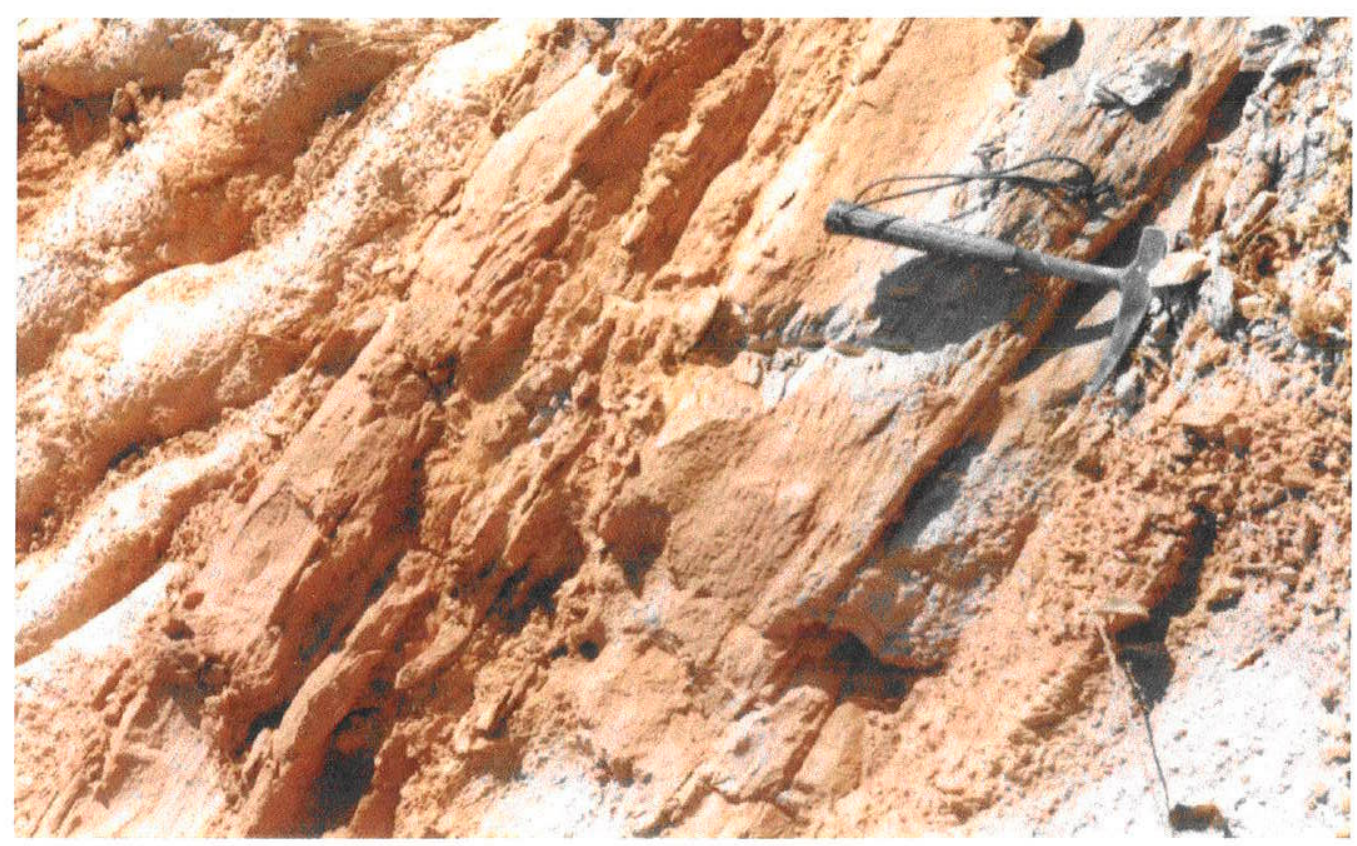

Foto 04. Metadiamictitos da Formação Rio Coxipó, com matriz arenosa cortados por veios de quartzo oblíquos, intercalados a metarenitos quartzosos plano-paralelos.

\subsubsection{Geologia Estrutural}

Os registros das feições tectônicas na área pesquisada, indicam uma evolução deformacional policíclica, onde destacam-se três fases distintas de deformação, aqui denominadas, D1, D2 e D3. A cada evento deformacional, associa-se a geração de uma família de estruturas secundárias específicas. Apresentaremos a seguir, em ordem cronológica, o quadro estrutural da área procurando caracterizar todos os elementos estruturais que correspondem a cada fase de deformação.

As deformações D1 e D2, são coaxiais e longitudinais ao trend do Cinturão Paraguai, enquanto a deformação tardia D3, tem um caráter rúptil-dúctil e orienta-se ortogonalmente às anteriores. 


\section{Estrutura da Fase de Deformacão D1}

A fase de deformação mais intensa que afetou o Grupo Cuiabá, é a responsável pela nucleação e desenvolvimento da anticlinal invertida regional que condiciona a distribuição das unidades litológicas locais. Associam-se geneticamente ao dobramento regional uma grande diversidade de estruturas tectônicas, descritas a seguir.

Dobramento maior D1. Descreve uma anticlinal assimétrica, invertida, com caimento suave, em torno de $10^{\circ}$, para NE. O plano axial orienta-se em torno de $\mathrm{N} 40^{\circ}$ $50^{\circ} \mathrm{E}$, com mergulhos da ordem de $40^{\circ}$ a $50^{\circ}$ para NW, indicando uma vergência para 0 interior da faixa dobrada (SE) e não para o antepaís. $\mathrm{Na}$ área, o núcleo antiformal esta constituído pela Formação Miguel Sutil e o flanco invertido(SE), está materializado pelos metadiamictitos da Formação Rio Coxipó. (Vide Mapa Geológico e Seção Geológica, Anexo 02).

Dobras parasitas D1. São desenhadas pelo acamadamento sedimentar (S0) principalmente nos filitos laminados $e$ intercalações de filitos com metarenitos da Formação Miguel Sutil. A geometria/simetria destas estruturas ( $M, S$ e $Z$ ) denunciam a sua localização ao longo da dobra maior, no flanco inverso, por exemplo no afloramento próximo ao Viaduto da Av. Fernando Corrêa da Costa (Foto 06), o aleitamento descreve uma assimetria em $\mathrm{S}$, e mergulhos superiores (em torno de $70^{\circ}$ NW) aos da foliação plano axial (em torno de $45^{\circ} \mathrm{NW}$ ); na estrada para $\mathrm{N}$. Sra. da Guia, a uns 3 quilômetros após o Trevo da Chapada dos Guimarães, os leitos de metarenitos configuram dobras em $\mathrm{Z}$ e mergulhos mais suaves que a foliação principal $\mathrm{S} 1$. As atitudes dos elementos geométricos das dobras parasitas coincidem, quase sempre, com os do dobramento regional, havendo em alguns casos algumas diferenças que refletem a superposição das deformaçōes mais jovens D1 e D2. A predominância dos mergulhos das camadas e laminações para NW, retratam a assimetria da anticlinal e o transporte tectônico para SE, conforme demonstra os diagramas de freqüência das medidas de SO. 


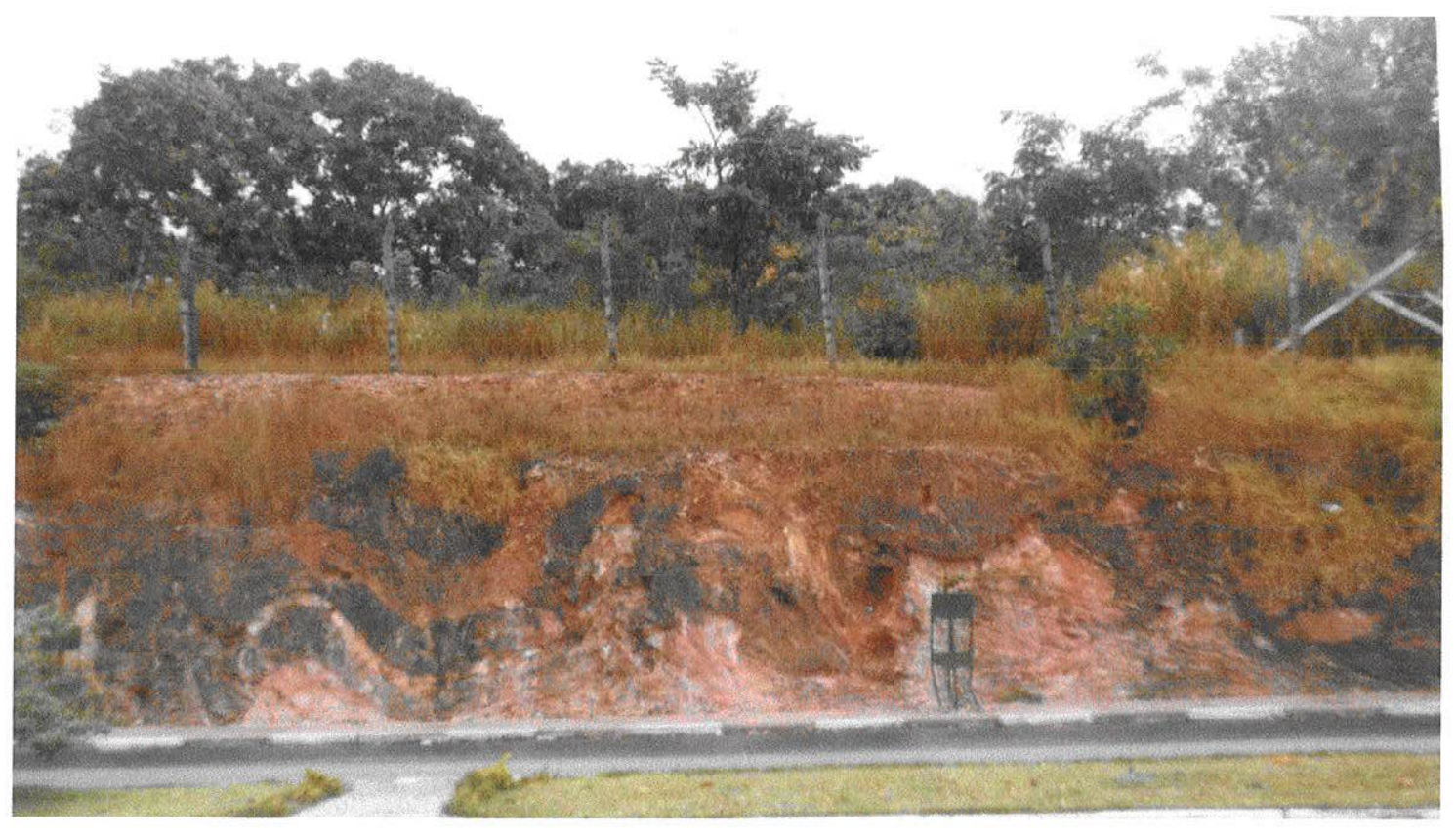

Foto 05. Dobras parasitas assimétricas desenvolvidas em intercalações de metarenitos quartzosos e filitos sericíticos da Formação Miguel Sutil.

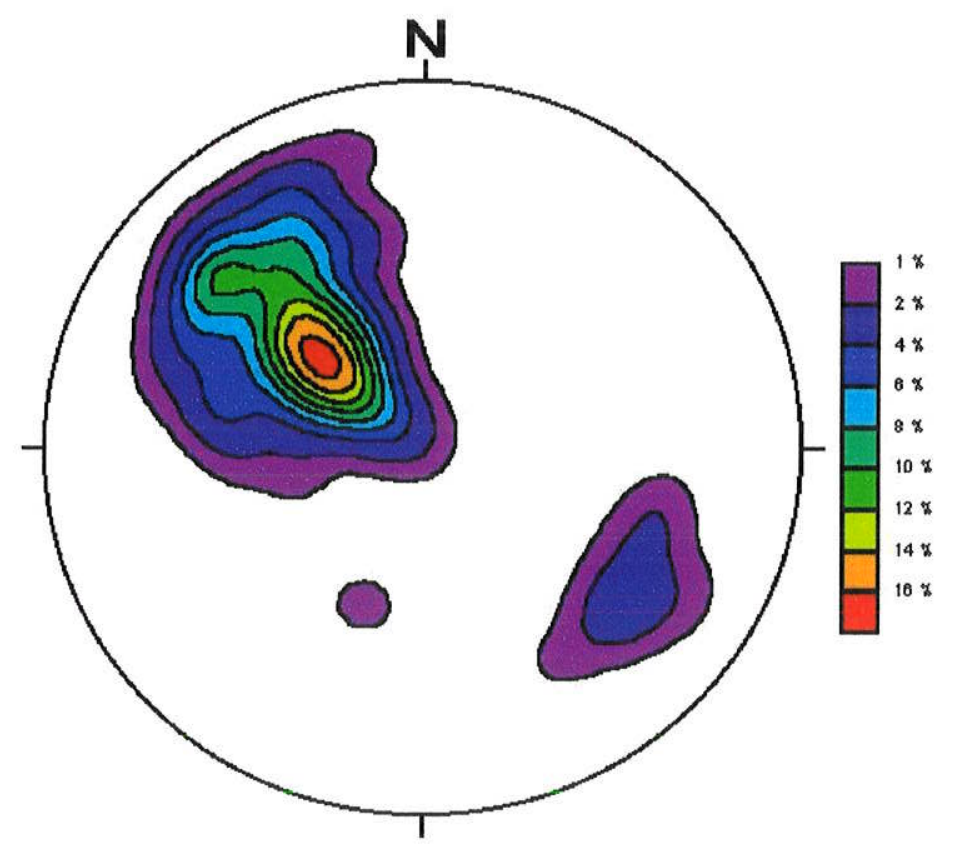

Figura 08. Diagrama de freqüência das medidas de SO. O estereograma descreve um dobramento assimétrico de acamamento com eixo caindo suavemente para NE e os flancos mergulhando principalmente para NW. $(\mathbf{N}=130)$. 
Foliação plano-axial S1. Esta estrutura penetrativa, que ora descreve uma xistosidade nos diamictitos, arenitos e conglomerados e ora, uma clivagem ardosiana, nos filitos sericíticos, mostra-se fortemente impressa em todos os litotipos, sendo uma clara evidência do encurtamento crustal e dos rearranjos físico-químicos, que afetaram o Grupo Cuiabá durante o Ciclo Brasiliano no Neoproterozóico.

A xistosidade penetrativa (S1), nos metadiamictitos da Formação Rio Coxipó, manifesta-se através do acentuado achatamento e rotação do clastos, conferindo a estes um formato do tipo oblato ou "pancake", típicos dos tectonitos $S$ e nos metarenitos e conglomerados quartzosos da Formação Miguel Sutil, expressa-se através rotações, achatamentos e recristalizações de quartzo, que definem um arranjo planar penetrativo, (Foto 07). Nos filitos sericíticos a foliação regional principal (S1) é definida por uma fábrica planar penetratriva produzida principalmente pela reordenação dos constituintes micáceos, recristalizações orientadas e formação de tênues filmes de óxidos. Nestas rochas a foliação (S1) é descrita como uma clivagem ardosiana. (Foto 08).

Os diagramas de freqüência para as medidas de foliação $S 1$, indicam uma concentração máxima da ordem de $\mathrm{N} 40^{\circ}-50^{\circ} \mathrm{E}$, com mergulhos variando entre $30^{\circ}$ a $55^{\circ}$ para NW, o que coincide, aproximadamente, com atitude da superfície axial do anticlinal regional. 


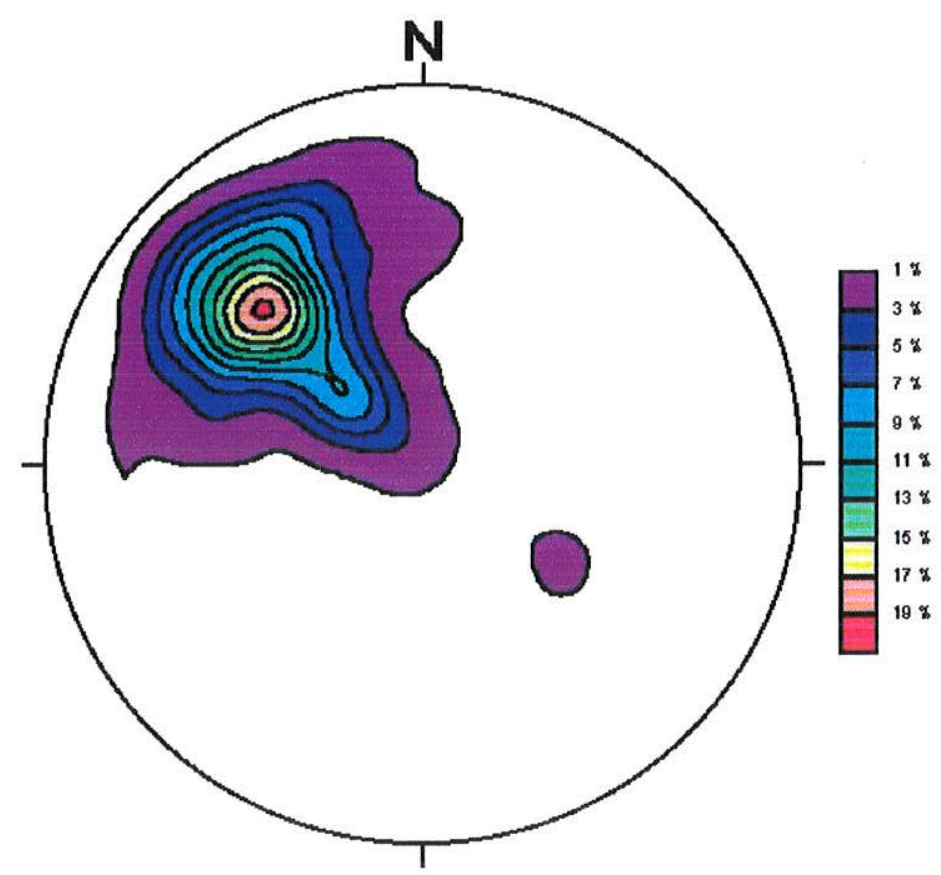

Figura 09. As atitudes da foliação $S 1$, mostram uma concentração máxima em $\mathrm{NW}$, indicando que mergulham preferencialmente neste gradiente. $(\mathbf{N}=\mathbf{2 3 7})$.

Falhas reversas F1. As falhas reversas, observadas na escala mesoscópica, refletem o padrão de transporte tectônico para SE. Estas estruturas relacionam-se geneticamente ao dobramento D1 sendo resultantes de acomodações rupteis nucleadas, principalmente, nos flancos invertidos das mesodobras parasíticas. Descontinuidades menores, juntas e microfalhas, desenvolvem-se subparalelamente as falhas principais.

Veios associados a D1. As principais gerações de veios de quartzo do Grupo Cuiabá estão vinculadas a esta primeira fase de deformação D1. São reconhecidos pelo menos quatro famílias de veios gerados durante a da deformação e metamorfismo que ocorreram durante a fase D1. Os veios mais antigos são tabulares, subconcordantes com a aleitamento original, apresentam textura maciça, espessura em torno de 1 a $5 \mathrm{~cm}$ e, freqüentemente mostram-se dobradas por D1. Os veios discordantes, os que cortam ortogonalmente o aleitamento, podem ser separados segundo a sua forma em, tabulares, lenticulares e em pares conjugados. Estes são 
maciços ou fibrosos, com espessura variável, chegando até a valores próximos a $2 \mathrm{~m}$, não apresentam vestígios de dobras D1, no entanto, a foliação S1 está fortemente impressa através de superfícies de descontinuidades regularmente espaçadas, que caracterizam uma clivagem disjuntiva (S1). O diagrama de freqüência para medidas de veios e os diagramas de rosácea, definem com clareza a ocorrência dos veios discordantes e concordantes com o aleitamento. (Foto 01).

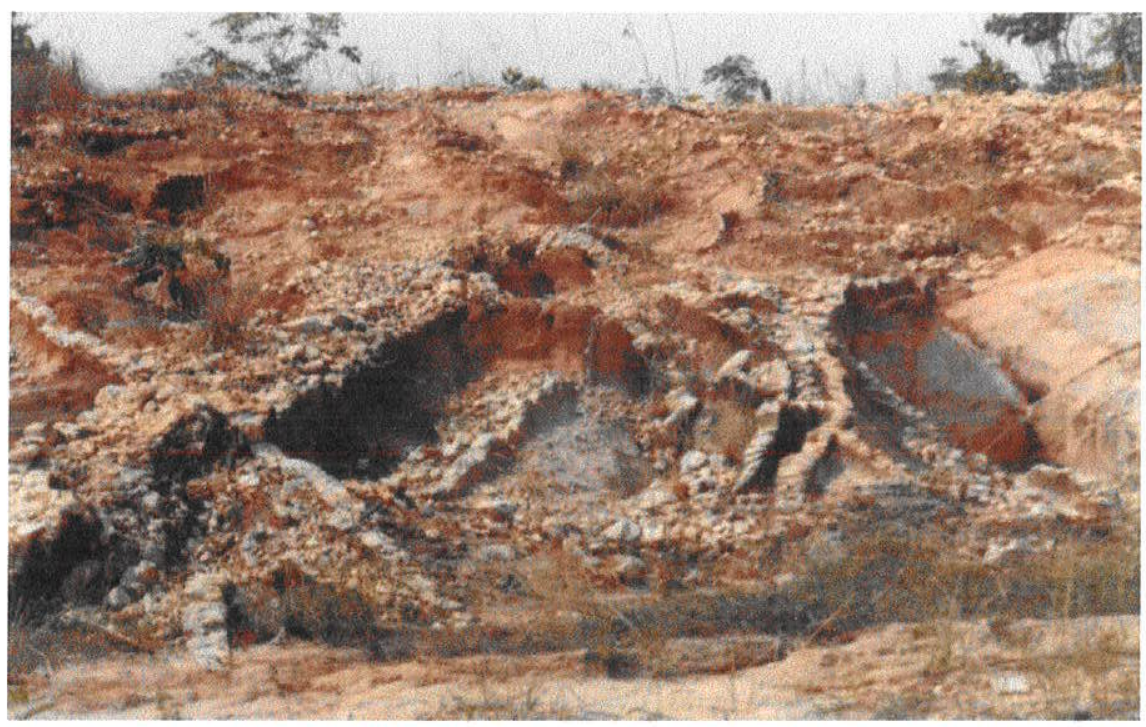

Foto 06. Metarenitos conglomeráticos quartzosos, recortados por veios de quartzo conjugados da Formação Miguel Sutil.

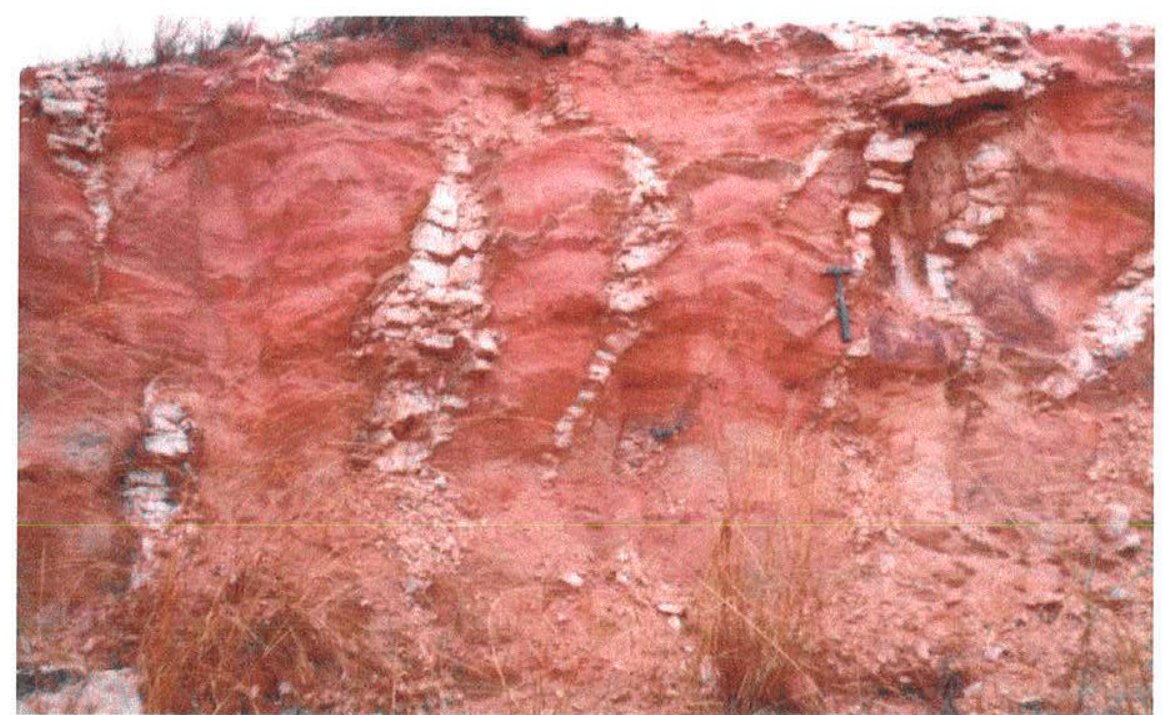

Foto 07. Metarenitos conglomeráticos quatzosos, cortados por veios de quartzo lenticulares da Formação Miguel Sutil. 
Os veios discordantes são fraturas de alívio preenchidas, que foram geradas como uma resposta ao encurtamento crustal NW-SE. A orientação predominante dos veios de alívio, $\mathrm{N} 50^{\circ}-70^{\circ} \mathrm{W}$ e mergulhos próximos a $90^{\circ}$, bem como a ocorrência de textura fibrosa e veios conjugados, corroboram um quadro regional de extensão crustal para NE-SW, em resposta ao encurtamento provocado pelos dobramentos regionais D1.

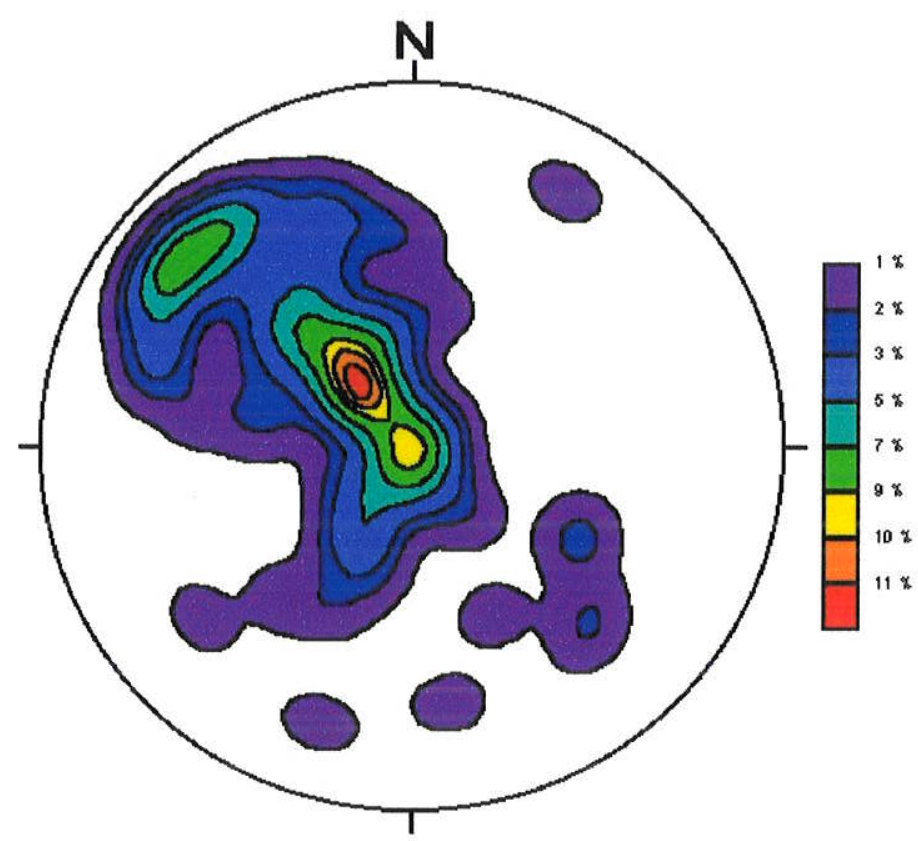

Figura 10. Veios de quartzo. $(\mathbf{N}=97)$.

\section{Estruturas da Fase de Deformação D2}

Esta fase de deformação caracteriza-se por uma mudança no sentido do transporte tectônico, agora em direção ao antepaís cratônico (de SE para NW) e pelo desenvolvimento de estruturas tectônicas comuns a níveis crustais mais rasos e que expressam uma intensidade menor dos esforços compressivos.

Dobras mesoscópicas D2. São ondulações abertas, assimétricas, inversas ou normal, as vezes em chevron, com suave caimento para NE, e que afetam, indiscriminadamente, os aleitamentos e a foliação S1. A assimetria, principalmente em $Z$, e o mergulho do plano axial para o quadrante SE, indicam a vergência tectônica para 
NW, em direção ao Cráton Amazônico. A superfície axial das dobras D2, orientam-se segundo a direção $\mathrm{N} 30^{\circ}-40^{\circ} \mathrm{E}$ mergulhando para SE com valores altos, que variam de $80^{\circ}$ a $65^{\circ}$.

Os diagramas de freqüência para as foliações $S 1$, em setores onde as dobras D2 nuclearam-se mais intensamente, mostram uma dispersão incipiente das medidas ao longo de uma guirlanda de círculo máximo, o que deve corresponder ao efeitos das ondulações D2 sobre as foliação existente.

Foliação plano-axial S2. Expressa-se através de uma clivagem de crenulação e, muito raramente, por uma clivagem disjuntiva. As superfícies de clivagem não tem um caráter penetrativo e seu espaçamento varia de alguns milímetros a centímetros, dependendo do tipo de rocha afetada. Freqüentemente desenvolve uma marcante superfície de partição que confere à rocha um aspecto fraturado. A estes planos de partição, podem associar-se pequenos deslocamentos, que caracterizam micro e mesofalhas reversas com transporte em direção a área cratônica a NW. Os diagramas de freqüência para as medidas da foliação $S 2$, indicam uma clara relação cogenética com as dobras D2, coincidindo com a orientação da superfície axial. Os estereogramas indicam uma concentração máxima de $\mathrm{N} 30^{\circ}-40^{\circ} \mathrm{E}$ com mergulhos variando entre $80^{\circ}$ a $40^{\circ}$ para SE. 


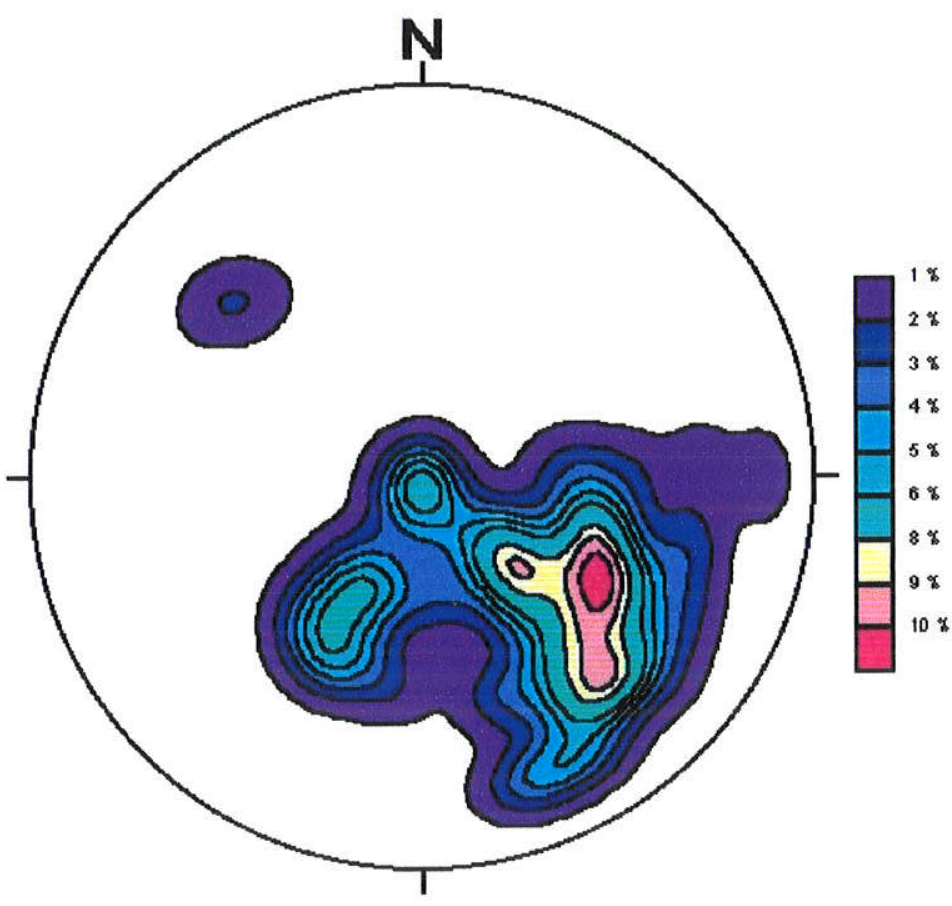

Figura 11. O estereograma para foliação S2, mostra uma certa dispersão principalmente no quadrante $\mathrm{SE}$, o que indica uma superfície de descontinuidade com mergulhos variáveis para SE. ( $\mathbf{N}=\mathbf{9 1})$.

Veios. Os veios de quartzo relacionados ao evento D2, ocupam preferencialmente as partições paralelas as clivagens de crenulação. São finos, em média $1 \mathrm{~cm}$ de espessura, descontínuos e irregulares, com textura maciça. As raras ocorrências de veios de quartzo gerados durante a fase D2, sugerem condições físicoquímicas pouco favoráveis a produção de grandes volumes de material remobilizado, indicando um nível crustal menos profundo e condições metamórficas brandas.

\section{Estruturas da Fase de Deformação D3}

Esta fase de deformação apresenta-se como ondulações de caráter regional, ortogonais as estruturas D1 e D3, caracterizada por dispersões das medidas do acamadamento ( $\mathrm{S} 0$ ) em torno do eixo $\mathrm{N} 60^{\circ}-70^{\circ} \mathrm{W}$. O caráter rúptil-dúctil deste evento evidencia-se pelo desenvolvimento de chevrons e dobras simétricas, associadas a clivagens disjuntivas e a um intenso diaclasamento regional de direção NW. 
Mesodobras D3. Esta família de estruturas ocorre localmente e retrata uma mudança na orientação do vetor dos esforços compressivos. As dobras são invariavelmente centimétricas, suaves a abertas, as vezes em chevron, com superfície axial orientada segundo a direção $\mathrm{N} 60^{\circ}-70^{\circ} \mathrm{W}$, da ordem $70^{\circ}$ a $85^{\circ}$ ora para $\mathrm{NE}$, ora para SW. A orientação da linha de charneira, mostra uma grande dispersão nos valores do caimento - de $10^{\circ}$ a $70^{\circ}$ para $N 60^{\circ}-70^{\circ} \mathrm{W}$ - o que é conseqüência das variações das atitudes das superfícies dobradas preexistentes - especialmente o aleitamento (SO) e a foliação (S1).

Foliação plano-axial S3. Esta estrutura planar não penetrativa, expressa-se na área por uma clivagem disjuntiva ou de crenulação, visível principalmente na superfície de foliação S1. Esta estrutura é responsável pela intensa partição ao longo da direção $\mathrm{N} 60^{\circ}-70^{\circ} \mathrm{W}$, que afeta indistintamente todo o Grupo Cuiabá, podendo, em certos casos, estar preenchida por finos veios de quartzo leitoso. Os diagramas de freqüência para estas clivagens indicam uma máxima concentração em torno de $\mathrm{N} 60^{\circ}-70^{\circ} \mathrm{W}$, com mergulhos altos, por volta de $85^{\circ}$ a $70^{\circ}$, para NE ou SW.

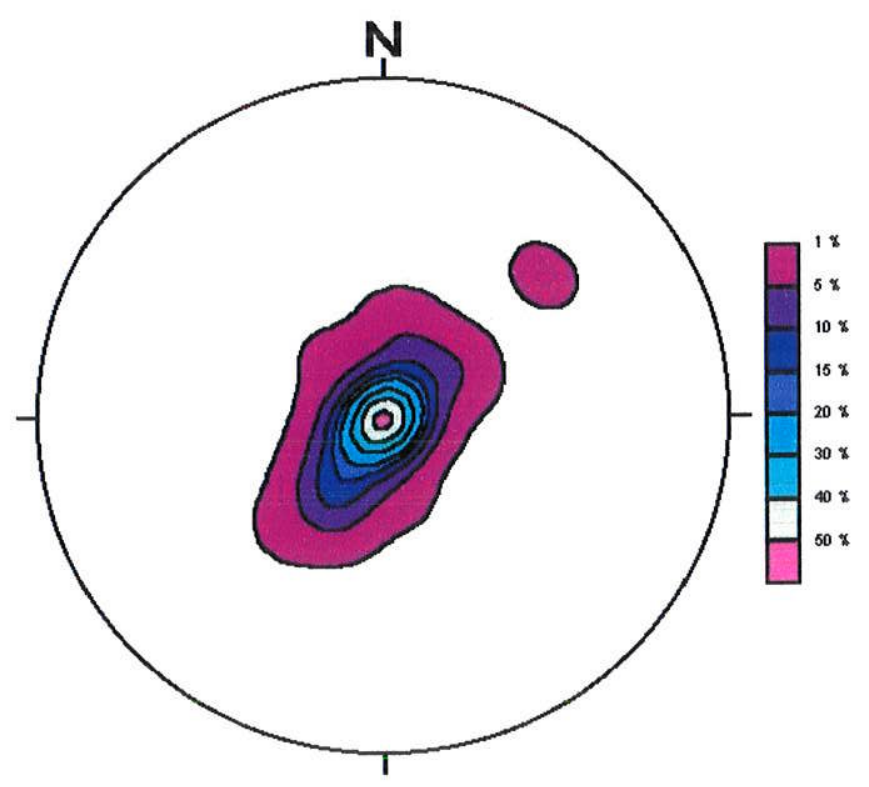

Figura 12. O estereograma para as clivagens $S 3$, importantes superfícies de descontinuidades regionais, indicam a existência de clivagens subverticalizadas perpendiculares a S1 e S2. ( $\mathbf{N}=\mathbf{8 2})$. 
Veios e diáclases. As diáclases paralelas a foliação S3 foram observadas em toda a área trabalhada, destacando-se sobremaneira nos metadiamictitos. Os veios de quartzo são raríssimos, e quando ocorrem são finos, em torno de 1 a $2 \mathrm{~cm}$, principalmente fibrosos, descontínuos e irregulares. Estas diáclases definem traçados perpendiculares ao trend da estruturação regional e exercem um forte controle na paisagem e no fluxo da água superficial.

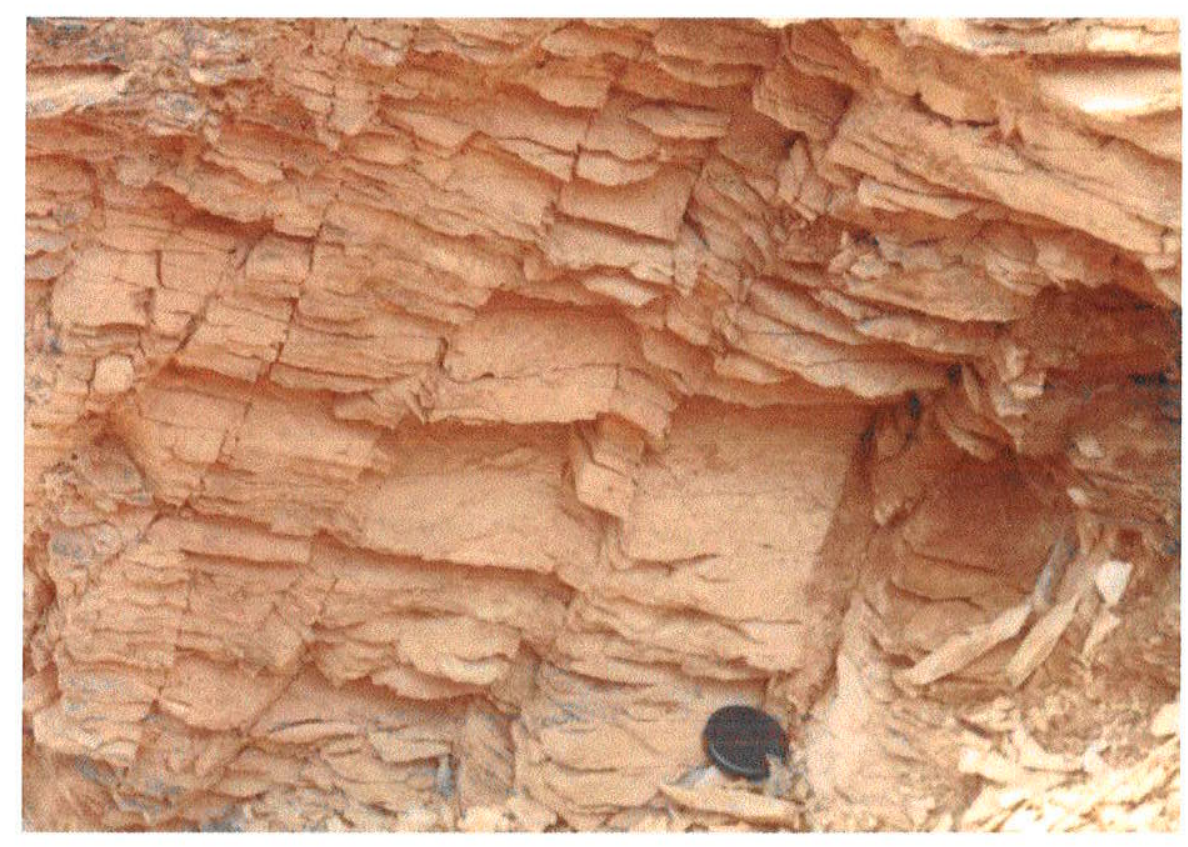

Foto 08. Desenvolvimento de clivagem disjuntiva paralelas em metadiamictitos da Formação Rio Coxipó.

5.2.6. A relação entre as litologias e as estruturas geológicas, com o controle das águas subterrâneas

Procuramos a seguir estudar a contribuição entre as litologias e as estruturas geológicas, com o comportamento do armazenamento e circulação das águas subterrâneas. 


\section{Formação Miguel Sutil}

Nos metassedimentos da Formação Miguel Sutil nota-se uma diferença marcante na instalação de fraturas e veios de quartzo nas litofácies pelítica (com laminação plano paralela) e na litofácies argilo-areno-conglomerática, nas áreas urbanas de Cuiabá e Várzea Grande. Enquanto o primeiro apresenta uma baixa intensidade de fraturas e veios de quartzo, o segundo mostra-se extremamente diaclasado, com diferentes famílias de juntas e ricos veios de quartzo de várias gerações. Este quadro é resultado, principalmente, da diferença de comportamento mecânico das duas litofácies quando submetidos a ação dos esforços. Por um lado, enquanto a litofácies pelítica tende a apresentar um comportamento mais dúctil (foliação e dobras), por outro, a litofácies argilo-areno-conglomerática comporta-se de forma rúptil, ou seja, sofrem rupturas e deslocamentos das falhas. Como resultado, encontramos as melhores condiçōes de armazenamento e circulação de água subterrânea na litofácies argilo-areno-conglomerática.

Um outro parâmetro que influencia a condutividade hidráulica refere-se à textura das rochas. A litofácies pelítica é rica em micas orientadas que definem sua foalição. Estas, por sua vez, dificultam a infiltração de água subterrânea. No entanto, a litofácies argilo-areno-conglomerática, especialmente as mais grosseiros, apresentam uma textura granular, o que resulta em uma maior porosidade e permeabilidade.

Não devemos esquecer também que a alteração da litofácies argilo-arenoconglomerática forma um solo arenoso muito propício à infiltração de águas pluviométricas, formando, desta maneira, excelentes áreas de recarga. Enquanto que, a alteração da litofácies pelítica forma um solo argiloso, laterizado e de pequena profundidade, que retém a infiltração das águas pluviométricas.

Os veios de quartzo desenvolvem-se principalmente nas litologias arenosas e conglomeráticas da Formação Miguel Sutil. São subverticais, perpendiculares as clivagens (S1 e S2) e auxiliam o processo de infiltração das águas subterrâneas nessas litologias. 
Por estas razões a Litofácies Pelito-Areno-Conglomerática é a unidade que apresenta as melhores condições de armazenamento e circulação de águas subterrâneas dos metassedimentos da Formação Miguel Sutil.

\section{Formação Rio Coxipó}

Esta unidade esta representada na área por duas associações litológicas, os metadiamictitos de matriz argilosa com raras intercalações de areia fina a média e os metadiamictitos de matriz arenosa intercalados a arenitos médios a grossos. Pela análise litológica da Formação Rio Coxipó, observa-se que as melhores condições aqüiferas estão localizadas na segunda associação, isto é, nos metadiamictitos de matriz arenosa.

As principais superficies de descontinuidades rochosas e os veios de quartzo do Grupo Cuiabá, na região estudada, relacionam-se às fases de dobramentos que afetaram a região.

Associado a primeira fase de dobramento, foi gerada a superficie de foliação, afetando todas as unidades com direção preferencial $N 40^{\circ}-50^{\circ} \mathrm{E}$ e mergulho para $50^{\circ}-$ $60^{\circ}$, principalmente para NW. Essas superfícies embora penetrativas, são fechadas e não facilitam a infiltração de água subterrânea.

Por outro lado às foliações S1 e S2 (clivagens de crenulação e disjuntivas), a primeira com direção $\mathrm{N} 40^{\circ}-50^{\circ} \mathrm{E}$ e mergulhos variáveis para SE e a outra é ortogonal a S1 e preferencialmente perpendiculares, são originadas por esforços cisalhantes, formando superfícies de descontinuidades ligeiramente abertas, o que facilita a percolação de água subterrânea. Essas superfícies de descontinuidades (clivagens) são melhor desenvolvidas nos metadiamictitos e metargilitos, sendo provavelmente responsáveis pelas águas subterrâneas encontradas nestas litologias. É interessante observar que as intersecções dessas clivagens constituem setores mais propícios a infiltração e armazenamento da água subterrânea. 
Os esforços trativos associados ao primeiro evento de dobramento (D1) são responsáveis pela implantação de fraturas trativas, conjugadas ou não, e veios de quartizo perpendiculares ao trend regional. Tal assembléia de fraturas e veios com atitude média N 40-50 W e mergulhos elevados (70-90), são concordantes a S3 e respondem pelo principal fraturamento regional. As diáclases ocorrem mais intensamente nos metadiamictitos da Formação Rio Coxipó e nos metapelitos da Formação Miguel Sutil, enquanto os veios de quartzo são predominantes nos litofácies pelito-areno-conglomeráticos da Formação Miguel Sutil. 


\section{BALANÇO HÍDRICO}

\subsection{Introdução}

O solo é o reservatório natural de água para a vegetação. A entrada de água é representada pela precipitação, enquanto que, a saída é representada pela evapotranspiração. $O$ solo também tem a capacidade de armazenar água, permitindo que o excedente atinja, por percolação profundidade maiores, alimentando a recarga subterrânea.

O estudo deste capítulo teve como objetivo calcular a recarga subterrânea profunda para a região estudada.

O Estado do Mato Grosso possui cerca de $900.000 \mathrm{~km}^{2}$ de extensão territorial, com grande disponibilidade hídrica, onde se situam as principais nascentes de três grandes bacias hidrográficas brasileiras:

a) Bacia Amazônica;

b) Bacia Araguaia/Tocantina;

c) Bacia Platina.

A Bacia Platina no Estado do Mato Grosso; conhecida como Bacia do Alto Rio Paraguai, é dividida em cinco sub-bacias:

a) Bacia do Rio Paraguai;

b) Bacia do Rio Cuiabá;

c) Bacia do Rio São Lourenço / Rio Vermelho;

d) Bacia do Rio Itiquira / Rio Correntes;

e) Bacia do Pantanal.

A Bacia do Rio Cuiabá, tem como corpo de água principal o próprio Rio Cuiabá, que drena uma área aproximada de $28.000 \mathrm{~km}^{2}$ e abrange parte dos seguintes municípios: Acorizal, Campo Verde, Chapada dos Guimarães, Cuiabá, Jangada, Nobres, Nossa Senhora do Livramento, Nova Brasilândia, Rosário Oeste, Santo Antônio do Leverger e Várzea Grande. 
Constituem ainda parte da Bacia do Rio Cuiabá as sub-bacias do Rio Coxipó e Rio Manso.

O Rio Cuiabá tem suas nascentes no Município de Rosário Oeste, formado inicialmente por dois cursos de água, o Cuiabá da Larga e o Cuiabá Bonito. Estes apresentam suas cabeceiras na Serra Azul a 500 metros de altitude. O ponto de união desses dois cursos é denominado de Limoeiro, onde o rio passa a ser chamado Cuiabazinho. Logo abaixo, recebe as águas do Rio Manso, dobrando de volume, sendo deste ponto em diante denominado Rio Cuiabá.

Num percurso de 828 km, o Rio Cuiabá passa a percorrer a região do Pantanal, alagando grandes áreas e misturando suas águas com a de outros rios na planície alagável, sendo portanto, difícil mensurar, a sua área de influência. Estima-se que toda a bacia possua uma área de aproximadamente $100.000 \mathrm{~km}^{2}$.

O Rio Cuiabá pode ser dividido em 3 trechos que banham as seguintes localidades:

1) Alto Cuiabá: Rosário Oeste, Nobres, Nova Brasilândia, Campo Verde, Acorizal, Jangada e Chapada dos Guimarães;

2) Médio Cuiabá: Cuiabá, Várzea Grande, Nossa Senhora do Livramento e Santo Antônio do Leverger;

3) Baixo Cuiabá: Barão de Melgaço e Poconé.

\subsection{Metodologia}

Embora o objetivo deste trabalho tenha sido estudar, prioritariamente, a área das Regiões Metropolitanas de Cuiabá e Várzea Grande, tornou-se necessário, para a caracterização do Balanço Hídrico, estudar também, como área de abrangência, o trecho Médio Cuiabá, região conhecida como "Baixada Cuiabana", que compreende uma área deprimida entre a região dos planaltos da Província Serrana e o início da planície inundável (Pantanal). 
É importante salientar que, os dados utilizados neste capítulo representam, apenas uma ordem de grandeza e não números absolutos. Este é um procedimento comum, em muitos estudos hidrológicos e hidrogeológicos.

Segundo a "Proposta de Enquadramento dos Principais Rios da Bacia do Rio Cuiabá" (1996), a área do trecho médio Cuiabá, da Bacia do Rio Cuiabá é de 14.096,00 $\mathrm{Km}^{2}$.

As descargas médias mensais do trecho médio Cuiabá foram calculadas a partir dos dados coletados na Estação Rio Cuiabá-Porto / DNAEE - DNOS, no período de 1962 a 1983.

Os dados climatológicos utilizados no presente trabalho referem-se ao período de 1986 a 1998. Tais dados foram coletados na Estação Agroclimatológica Padre Ricardo Remetter. Esta Estação encontra-se localizada na Fazenda Experimental da Universidade Federal de Mato Grosso, situada na área suburbana de Santo Antonio de Leverger - MT, a $3 \mathrm{~km}$ de sua área central.

O método utilizado foi desenvolvido por Thornthwaite (1955), que utiliza dados de precipitação mensal, temperatura média mensal e anual, e estimativas de evapotranspiração potencial e real, para determinar a água armazenada no solo, excesso e deficiência hídrica. Neste método, os valores da evapotranspiração potencial são obtidos pelo método de Thornthwaite (1948), que se baseia na temperatura do ar.

A capacidade de armazenamento de umidade no solo (CAD), é uma característica da vegetação e independe do tipo de solo (Tubellis \& Nascimento, 1983). Para a região estudada (Baixada Cuiabana), onde predomina a região do cerrado, foi utilizado o CAD de 150mm, já utilizado anteriormente por Campelo \& Caseiro, 1989. 


\subsection{Resultados}

A tabela abaixo mostra a temperatura média mensal, para Santo Antônio do Leverger no período de 1986 a 1998, coletados na Estação Climatológica Padre Ricardo Remetter:

Tabela 3. Temperatura Média Mensal

\begin{tabular}{|l|l|l|l|l|l|l|l|l|l|l|l|l||}
\hline $\begin{array}{l}\text { TEM. } \\
\left({ }^{\circ} \mathrm{C}\right)\end{array}$ & JAN. & FEV. & MAR. & ABR. & MAI. & JUN. & JUL. & AGO. & SET. & OUT. & NOV. & DEZ \\
\hline 1986 & 26,9 & 26,7 & 26,4 & 26,7 & 25,2 & 22,1 & 21,9 & 25 & 24,6 & 25,8 & 28,2 & 27,2 \\
\hline 1987 & 26,9 & 26,4 & 25,7 & 26,7 & 24,2 & 22,8 & 24,6 & 23,7 & 27 & 28,4 & 27,4 & 26,8 \\
\hline 1988 & 26,9 & 26,5 & 27 & 26,5 & 24,1 & 22,3 & 22 & 24,1 & 27,1 & 28,4 & 27,5 & 26,9 \\
\hline 1989 & 26,1 & 26,2 & 26 & 26,3 & 23,3 & 24 & 21,1 & 25,5 & 24,8 & 27,1 & 27,3 & 26,2 \\
\hline 1990 & 26,5 & 26,5 & 26,8 & 26,5 & 23,8 & 23,9 & 22,2 & 26,5 & 24,4 & 27,8 & 27,7 & 27,3 \\
\hline 1991 & 27 & 27,4 & 26,3 & 25,8 & 25,1 & 23,2 & 22,3 & 24,1 & 26,9 & 27,3 & 27,2 & 27,4 \\
\hline 1992 & 26,7 & 26,5 & 26,5 & 26,3 & 25,8 & 24,6 & 20,5 & 24 & 24,5 & 26,9 & 26,5 & 27,3 \\
\hline 1993 & 26,9 & 25,8 & 26,8 & 26,7 & 23,8 & 22,6 & 21,5 & 23,1 & 26,3 & 27,7 & 27,8 & 27,4 \\
\hline 1994 & 27,1 & 26,6 & 26,8 & 26,5 & 25,2 & 23,5 & 22 & 23,7 & 26,7 & 27,5 & 27,5 & 26,7 \\
\hline 1995 & 26,6 & 26,1 & 27,1 & 25,4 & 23,9 & 23 & 23,8 & 23,7 & 27,2 & 27,7 & 27,2 & 26,8 \\
\hline 1996 & 26,8 & 26,9 & 27 & 26,3 & 25,1 & 20,6 & 22,3 & 26,6 & 25,9 & 27,5 & 26,9 & 27,8 \\
\hline 1997 & 26,6 & 26.7 & 26,9 & 26 & 24,8 & 24,3 & 22,7 & 24,3 & 28,9 & 29,5 & 28,7 & 28 \\
\hline 1998 & 28,4 & 27,7 & 27,9 & 27,6 & 23,2 & 22,9 & 23,9 & 26 & 25,9 & 27,7 & 28 & 27,1 \\
\hline Méd. & 26,9 & 26,6 & 26,7 & 26,4 & 24,4 & 23,0 & 22,3 & 24,6 & 26,2 & 27,6 & 27,5 & 27,1 \\
\hline \hline
\end{tabular}

A tabela abaixo mostra a precipitação mensal, para Santo Antônio do Leverger no período de 1986 a 1998, coletados na estação climatológica Padre Ricardo Remetter:

Tabela 4. Precipitação Mensal

\begin{tabular}{|l|l|l|l|l|l|l|l|l|l|l|l|l||}
\hline $\begin{array}{l}\text { PPT. } \\
\text { (mm) }\end{array}$ & JAN. & FEV. & MAR. & ABR. & MAI. & JUN. & JUL. & AGO. & SET. & OUT. & NOV. & DEZ. \\
\hline 1986 & 196,9 & 200,7 & 190 & 75,6 & 73,5 & 4,4 & 0,5 & 91,5 & 29 & 89,9 & 140,7 & 126 \\
\hline 1987 & 161 & 212,8 & 172 & 50,8 & 89 & 62 & 1,9 & 0 & 54 & 148,2 & 126,2 & 312,5 \\
\hline 1988 & 260,5 & 256,5 & 149,2 & 153,7 & 3,8 & 21,4 & 1,5 & 0 & 9,4 & 21,6 & 131,3 & 118,8 \\
\hline 1989 & 287,1 & 124,9 & 181,5 & 182 & 45,2 & 14 & 37,6 & 85,5 & 73,3 & 83,7 & 153,8 & 146 \\
\hline 1990 & 239,5 & 116,5 & 163,8 & 73,1 & 49,2 & 17,2 & 9,6 & 68,9 & 145,7 & 190,8 & 95,3 & 347,3 \\
\hline 1991 & 215,8 & 182 & 400,2 & 98,4 & 25,4 & 43,8 & 0 & 1,3 & 59 & 184,4 & 184 & 249,9 \\
\hline 1992 & 216,5 & 254,2 & 137,5 & 100,9 & 16,6 & 0 & 0 & 1,8 & 129,2 & 91,7 & 242,1 & 124,9 \\
\hline 1993 & 112,1 & 157,8 & 126,9 & 208,3 & 21,6 & 154,1 & 1,1 & 11,4 & 2,9 & 75,9 & 335,3 & 266,4 \\
\hline 1994 & 388,3 & 181,7 & 124,7 & 130,1 & 85,5 & 55,5 & 31,2 & 14 & 95,1 & 224,2 & 228,9 & 336,6 \\
\hline 1995 & 385,8 & 396 & 171,7 & 47,2 & 56,5 & 80,5 & 0 & 20,8 & 33,7 & 103,1 & 253,3 & 367,6 \\
\hline 1996 & 222,9 & 281,4 & 203 & 106,9 & 54,1 & 32,9 & 0 & 2 & 71,3 & 73 & 254,6 & 93,3 \\
\hline 1997 & 566,2 & 181,3 & 227,1 & 94 & 49,2 & 69 & 0 & 1,1 & 42,6 & 63,5 & 195 & 187,9 \\
\hline 1998 & 196,5 & 80,6 & 120,8 & 143,8 & 39,6 & 1,5 & 0 & 27,3 & 88,9 & 78,1 & 51,7 & 280 \\
\hline Méd. & 265 & 202 & 182,2 & 112,6 & 46,8 & 42,8 & 6,4 & 25 & 64,1 & 109,9 & 184 & 227,5 \\
\hline
\end{tabular}


A tabela abaixo mostra o Balanço Hídrico para Santo Antônio do Leverger, calculado pelo método de Thornthwaite-Mather (1955), no período de 1986 a 1998 :

Tabela 5. Balanço Hídrico

\begin{tabular}{|l|l|l|l|l|l|l|l|l||}
\hline MÊS & \multicolumn{1}{|c|}{$\begin{array}{c}\mathbf{T} \\
\left({ }^{\circ} \mathbf{C}\right)\end{array}$} & $\begin{array}{c}\mathbf{P} \\
(\mathbf{m m})\end{array}$ & $\begin{array}{c}\text { ETO } \\
(\mathbf{m m})\end{array}$ & $\begin{array}{c}\text { P-ETO } \\
(\mathbf{m m})\end{array}$ & $\begin{array}{c}\text { ARM } \\
(\mathbf{m m})\end{array}$ & $\begin{array}{c}\text { ER } \\
(\mathbf{m m})\end{array}$ & $\begin{array}{c}\text { EXC } \\
(\mathbf{m m})\end{array}$ & $\begin{array}{c}\text { DEF } \\
(\mathbf{m m})\end{array}$ \\
\hline Nov. & 27,5 & 184 & 154 & 30 & 30 & 154 & & \\
\hline Dez. & 27,1 & 227 & 158 & 69 & 99 & 158 & & \\
\hline Jan. & 26,8 & 265 & 153 & 112 & 150 & 153 & 61 & \\
\hline Fev. & 26,6 & 202 & 133 & 69 & 150 & 133 & 69 & \\
\hline Mar. & 26,7 & 182 & 145 & 37 & 150 & 145 & 37 & \\
\hline Abr. & 26,4 & 113 & 130 & -17 & 133 & 130 & & \\
\hline Mai. & 24,4 & 47 & 99 & -52 & 81 & 99 & & \\
\hline Jun. & 23,0 & 43 & 77 & -34 & 47 & 77 & & \\
\hline Jul. & 22,3 & 06 & 72 & -66 & 0 & 53 & & 19 \\
\hline Ago. & 24,6 & 25 & 103 & -78 & 0 & 25 & & 78 \\
\hline Set. & 26,1 & 64 & 127 & -63 & 0 & 64 & & 63 \\
\hline Out. & 27,6 & 110 & 154 & -44 & 0 & 110 & & 44 \\
\hline Totais & & 1467,9 & & & & 1248 & 167 & 204 \\
\hline
\end{tabular}

T: temperatura $\left({ }^{\circ} \mathrm{C}\right)$

P: precipitação $(\mathrm{mm})$

Eto: evapotranspiração de referência

ARM: armazenamento de água pelo solo
ER: estimativa da evapotranspiração real

EXC: excedente hídrico

DEF: deficiência hídrica

A tabela abaixo mostra as descargas médias mensais na Baixada Cuiabana (Médio Cuiabá), coletados na Estação Rio Cuiabá-Porto, no período de 1962 a 1983.

Tabela 6. Descargas Médias Mensais do Rio Cuiabá

\begin{tabular}{|l|c|}
\hline \multicolumn{1}{|c|}{ MESES } & $\begin{array}{c}\text { DESCARGA } \\
\text { (M }{ }^{3} / \text { SEG) }\end{array}$ \\
\hline Janeiro & 633 \\
\hline Fevereiro & 823 \\
\hline Março & 703 \\
\hline Abril & 406 \\
\hline Maio & 227 \\
\hline Junho & 145 \\
\hline Julho & 112 \\
\hline Agosto & 96 \\
\hline Setembro & 96 \\
\hline Outubro & 143 \\
\hline Novembro & 237 \\
\hline Dezembro & 421 \\
\hline Média & 336 \\
\hline
\end{tabular}


A tabela 5 apresenta as médias mensais do balanço hídrico para o período de 1986 a 1998. A tabela mostra que o volume de água armazenado pelo solo no mês de novembro $(30 \mathrm{~mm})$ foi menor do que a capacidade de armazenamento de umidade no solo (CAD) utilizada, que é de $150 \mathrm{~mm}$, não tendo havido portanto excedente para a infiltração subterrânea profunda. No mês de dezembro, o volume armazenado aumentou para $99 \mathrm{~mm}$, permanecendo ainda inferior a CAD. Já nos meses de janeiro, fevereiro e março, meses em que a precipitação pluviométrica mantinha o aumento que se iniciou em setembro/outubro, foi atingido a capacidade de armazenamento pelo solo $(C A D=150 \mathrm{~mm})$, tendo havido um excedente que pôde ser utilizado para a recarga subterrânea profunda. Nos meses seguintes, de abril a setembro, com o decréscimo da precipitação pluviométrica, o volume de água armazenado pelo solo, passou a ser menor que a $C A D$, não havendo excedente para a infiltração. Ocorrendo até mesmo, deficiência hídrica nos meses de julho a outubro.

Através desse balanço hídrico, verifica-se um excesso de $167 \mathrm{~mm}$, ou seja, esta é a água disponível para a infiltração. Vamos, então, calcular o seu volume para a Bacia do Médio Cuiabá (Baixada Cuiabana).

a) Volume de Chuva na Bacia:

$\mathrm{P}=1,468 \mathrm{~m}$ (totais de precipitação) $\times 14,096 \times 10^{9} \mathrm{~m}^{2}$ (área da bacia) $=20,7 \times$ $10^{9} \mathrm{~m}^{3} / \mathrm{ano}$

b) Pelo balanço hídrico, o volume infiltrado na bacia foi de $167 \mathrm{~mm}$, ou seja $11,3 \%$ de $P$, que é $2,35 \times 10^{9} \mathrm{~m}^{3} / a n o$ (nos meses de janeiro, fevereiro e março).

O escoamento básico subterrâneo ou descarga subterrânea, pode ser estimado a partir da descarga média de agosto, mês em que não houve armazenagem de água pelo solo. Pela tabela 6, que mostra a descargas médias mensais na Bacia do Médio Cuiabá (região da Baixada Cuiabana), a descarga no mês de agosto foi de $93 \mathrm{~m}^{3} / \mathrm{s}$. Usando este valor para os meses de janeiro, fevereiro e março, quando houve excedente hídrico obtêm-se $746.496 .000 \mathrm{~m}^{3}$, que é o escoamento básico subterrâneo ou descarga subterrânea anual. 
A diferença entre o valor de infiltração na bacia $\left(2,35 \times 10^{9} \mathrm{~m}^{3} / \mathrm{ano}\right)$ menos o valor da descarga subterrânea $\left(746.496 .000 \mathrm{~m}^{3} / a n o\right)$, será o volume de recarga profunda para o aqüífero livre da Bacia do Médio Cuiabá, que é de $1.603 .504 .000 \mathrm{~m}^{3} / a n o$.

Lembrando que este tipo de calculo nos indica apenas uma ordem de grandeza, e que é valido apenas para aqüíferos livres, o estudo feito sugere que o volume de recarga profunda para a região da Baixada Cuiabana é de aproximadamente $1.603 .504 .000 \mathrm{~m}^{3} /$ ano. 
7. Levantamento de Dados Sobre os Sistemas Produtores, de Abastecimento e Saneamento da Área Estudada.

Nesta parte do trabalho apresentamos uma caracterização da região estudada. Serão abordados os seguintes aspectos: situação do sistema produtor, sistema de abastecimento de água, situação do saneamento, situação dos efluentes industriais e a situação sanitária das praias.

\subsection{Situações do Sistema Produtor da Região de Cuiabá e Várzea Grande.}

Tanto Cuiabá como Várzea Grande são abastecidas com água fornecida pela Companhia de Saneamento do Estado de Mato Grosso (SANEMAT), que conduz água tratada através de Estações de Tratamento de Água (ETA) e águas subterrâneas captadas por Poços Tubulares (PT).

De acordo com os relatórios técnicos dos arquivos da Área Operacional da SANEMAT de 1.987 a 1.996, a situação do Sistema Produtor de Água na região de Cuiabá e Várzea Grande - MT é a seguinte: 
Tabela 07. Produção de Água em Cuiabá

\begin{tabular}{|c|c|c|c|c|c|c|c|c|}
\hline Ano & $\begin{array}{l}\text { Volume } \\
\text { Captado } \\
\text { ETA } \\
\text { (mªno) }\end{array}$ & $\begin{array}{c}\text { Volume } \\
\text { Captado } \\
\text { PT } \\
\text { (mªno) }\end{array}$ & $\begin{array}{c}\text { Volume Pro- } \\
\text { duzido ETA } \\
\text { (m²/ano) }\end{array}$ & $\begin{array}{l}\text { Volume Pro- } \\
\text { duzido PT } \\
\left(\mathrm{m}^{3} / a n o\right)\end{array}$ & $\begin{array}{c}\text { Volume } \\
\text { Perda ETA } \\
\text { (m²/ano) }\end{array}$ & $\begin{array}{l}\text { Indice de } \\
\text { Perda (\%) }\end{array}$ & $\begin{array}{l}\text { População } \\
\text { Abastecida } \\
\text { (habitantes) }\end{array}$ & $\begin{array}{c}\text { Volume Total } \\
\left.\text { Produzido ( } \mathrm{m}^{3} / \mathrm{ano}\right)\end{array}$ \\
\hline 1996 & 61.077 .560 & 2.740 .292 & 59.708 .063 & 2.740 .292 & 1.369 .497 & 55,6 & 503.460 & 62.448 .355 \\
\hline 1995 & 59.137 .967 & 2.604 .085 & 57.883 .877 & 2.604 .085 & 1.254 .090 & 57,4 & 486.160 & 60.487 .962 \\
\hline 1994 & 60.039 .735 & 2.483 .271 & 58.268 .602 & 2.483 .272 & 1.771 .133 & 60,0 & 467.180 & 60.751 .874 \\
\hline 1993 & 60.279 .210 & 2.744 .254 & 58.910 .855 & 2.744 .254 & 1.368 .355 & 59,7 & 371.500 & 61.655 .109 \\
\hline 1992 & 59.049 .115 & 2.593 .836 & 57.605 .230 & 2.593 .836 & 1.443 .885 & 65,6 & 353.530 & 60.199 .066 \\
\hline 1991 & 56.979 .564 & 2.323 .992 & 55.674 .633 & 2.323 .992 & 1.304 .931 & 60,0 & 335.230 & 57.998 .625 \\
\hline 1990 & 46.639 .972 & 2.282 .946 & 45.441 .232 & 2.282 .947 & 1.198 .740 & & & 47.724 .179 \\
\hline 1989 & 46.470 .857 & 2.534 .192 & 45.641 .003 & 2.534 .192 & 829.854 & & & 48.175 .195 \\
\hline 1988 & 45.572 .802 & 2.171 .925 & 43.791 .962 & 2.171 .925 & 1.780 .840 & & & 45.963 .887 \\
\hline 1987 & 45.115 .465 & 1.738 .845 & 42.430 .799 & 1.738 .845 & 2.684 .666 & & & 44.169 .644 \\
\hline
\end{tabular}

Tabela 08. Produção de água em Várzea Grande

\begin{tabular}{|c|c|c|c|c|c|c|c|c|}
\hline Ano & $\begin{array}{c}\text { Volume } \\
\text { Captado } \\
\text { ETA } \\
\left(\mathrm{m}^{3} / \text { ano }\right)\end{array}$ & $\begin{array}{c}\text { Volume } \\
\text { Captado } \\
\text { PT } \\
\left(\mathrm{m}^{3} / \mathrm{ano}\right)\end{array}$ & $\begin{array}{c}\text { Volume Pro- } \\
\text { duzido ETA } \\
\text { (mªno) }\end{array}$ & $\begin{array}{c}\text { Volume } \\
\text { Produzido } \\
\text { PT } \\
\text { (mªno) }\end{array}$ & $\begin{array}{c}\text { Volume } \\
\text { Perda ETA } \\
\left(\mathrm{m}^{3} / \mathrm{ano}\right)\end{array}$ & $\begin{array}{l}\text { Indice de } \\
\text { Perda (\%) }\end{array}$ & $\begin{array}{l}\text { População } \\
\text { Abastecida } \\
\text { (habitantes) }\end{array}$ & $\begin{array}{c}\text { Volume Total } \\
\text { Produzido }\left(\mathrm{m}^{3} / \mathrm{ano}\right)\end{array}$ \\
\hline 1996 & 15.728 .424 & 7.393 .500 & 14.901 .058 & 7.393 .500 & 827.366 & 64,6 & 179.570 & 22.294 .558 \\
\hline 1995 & 14.150 .961 & 6.131 .723 & 13.452 .907 & 6.131 .723 & 698.054 & 63,0 & 165.780 & 19.584 .630 \\
\hline 1994 & 14.312 .663 & 5.540 .415 & 13.736 .435 & 5.540 .415 & 576.228 & 56,3 & 155.500 & 19.276 .850 \\
\hline 1993 & 10.253 .910 & 5.945 .143 & 9.663 .462 & 5.945 .143 & 590.448 & 63,1 & 135.730 & 19.608 .605 \\
\hline 1992 & 10.971 .829 & 6.717 .109 & 10.386 .230 & 6.717 .109 & 585.599 & 71,6 & 122.450 & 17.103 .339 \\
\hline 1991 & 9.679 .859 & 6.066 .648 & 9.215 .193 & 6.066 .648 & 464.666 & 64,0 & 111.660 & 15.281 .841 \\
\hline 1990 & 7.518 .484 & 5.785 .483 & 7.129 .716 & 5.785 .483 & 388.768 & & & 12.915 .199 \\
\hline 1989 & 6.882 .048 & 4.960 .550 & 6.577 .100 & 4.960 .550 & 304.948 & & & 11.537 .650 \\
\hline 1988 & 7.061 .277 & 3.687 .540 & 6.742 .477 & 3.687 .540 & 318.800 & & & 10.430 .017 \\
\hline 1987 & 7.714 .912 & 2.381 .203 & 7.383 .912 & 2.381 .203 & 331.000 & & & 9.765 .115 \\
\hline
\end{tabular}


Observa-se nas Tabelas 07 e 08 , que $\circ$ volume de água produzido pela SANEMAT para as regiões de Cuiabá e Várzea Grande mostra-se, de certo modo, satisfatório, porém apresenta um índice de perda muito elevado com média de 59,7\% para Cuiabá e 63,7 \% para Várzea Grande.

Alguns dos processos de perda d'água possíveis de ocorrer em Cuiabá e Várzea Grande:

1. Perda no processo de produção das estações de tratamento de água (ETA) na lavagem dos filtros. Esta perda é estimada em 3,2\% do volume captado e tem como destino as galerias de água pluvial, conseqüentemente cai nos córregos da região e, posteriormente, no Rio Cuiabá.

2. Perda ocasionada por interrupção do tempo disponivel de captação, que compreende o volume não retirado dos mananciais superficiais e subterrâneos e não aproveitável fisicamente, por problemas de manutenção preventiva e corretiva. Os fatores que ocasionam esta perda podem ser causados pela interrupção de energia, rompimento de adutora, pane em equipamento, perda de operação na execução do serviço. Esta perda é estimada em 1,3\% do tempo previsto de trabalho.

3. Perdas decorrentes do volume de fugas toleráveis. Esta perda é decorrente dos milhões de juntas existentes nas tubulações e peças especiais, na qual é impossivel haver estanqueidade total. Segundo a SANEMAT, esta perda vai necessariamente ao manancial subterrâneo e é estimada pelo produto de $0,0041 \mathrm{l} / \mathrm{s}$ por quilômetro de rede de distribuição. Sabendo-se que Várzea Grande possui $435,53 \mathrm{~km}$ de rede de distribuição e Cuiabá, $1.553,40 \mathrm{~km}$, calculamos as perdas que têm como destino o manancial subterrâneo (recarga artificial) que resultaram em 56.312.983 /ano para Várzea Grande e 200.850.892 I/ano para Cuiabá, perfazendo um volume total de 257.163.875 I no ano de 1.996.

4. Perdas na construção dos reservatórios. São perdas decorrentes de defeitos técnicos na construção dos reservatórios de concreto, como trincas e fraturas do 
mesmo. Esta perda não é estimada em Cuiabá e Várzea Grande por não haver equipamentos de controle.

5. Perdas decorrentes de vazamento:

a) Perda relacionada à vida útil do material. Por exemplo, a vida útil dos tubos de cimento amianto é de 20 anos e toda rede de distribuição do centro da cidade de Cuiabá é de cimento amianto instalado há mais de 20 anos.

b) Perda relacionada a assentamento da rede de distribuição fora dos padrões previstos pelo fabricante. Por exemplo, a profundidade das valetas e mudanças na pressão da pista de rolamento. Com este tipo de vazamento, estabelece-se uma característica de manutenção corretiva para o reparo de substituição do material danificado. Vale ressaltar que numa tubulação de $3 / 4 "$ de diâmetro pode perder 0 produto de $0,15 \mathrm{l} / \mathrm{s}$ pelo tempo em que o reparo não foi executado, até cerca de $162,5 \mathrm{l} / \mathrm{s}$ em uma tubulação de $600 \mathrm{~mm}$ de diâmetro. Este tipo de vazamento tem como destino o manancial subterrâneo. Esta perda é estimada pelo produto do número de eventos (reparos) apresentados pelo diâmetro da tubulação e pela vazão correspondente da tubulação.

6. Perdas comerciais. São todos os artifícios utilizados pelo usuário para lesar a concessionária. Esta, por sua vez, mostra-se deficiente no sentido de uma fiscalização e controle da situação. Estima-se em torno de 11 a $12 \%$ do volume produzido. É interessante observar, que parte dessa perda tem como destino o manancial subterrâneo.

7. Perdas referentes a característica da hidrometação.

a) Margem de erro permissível na produção do hidrômetro, de 2 a $5 \%$ da capacidade de medição do mesmo.

b) Vida útil do hidrômetro, isto é, a cada $5.000 \mathrm{~m}^{3}$ ou 5 anos, deverá ser reativado a manutenção preventiva (teste de bancada). Caso não seja realizado, aumentará os 
índices de perda, pois o dispositivo de medição apresentará alterações no sentido de registrar valores menores de água em relação ao valor real consumido.

8. Perdas domésticas decorrentes do mau uso: lavagem de automóveis, calçada, residência, ruas e outras. Uma parte desta perda é absolvida pelo solo.

7.2. Sistema de Abastecimento de Água em Cuiabá e Várzea Grande (1996).

Todas as informações contidas nos itens seguintes foram obtidas de Teixeira (1997): Monografia de Especialização em Qualidade Ambiental e Recursos Hídricos Depto. De Engenharia Sanitária e Ambiental.

\subsubsection{Captação e Distribuição de Água}

\section{Captação Superficial para Cuiabá:}

Sistema Lipa (Rio Cuiabá) - $1.325 \mathrm{l} / \mathrm{s}$

Sistema Porto (Rio Cuiabá) - $112 \mathrm{l} / \mathrm{s}$

Sistema Tijucal Velho (Rio Coxipó) - 112 1/s

Sistema Tijucal Novo (Rio Coxipó) $-410 \mathrm{l} / \mathrm{s}$

Sistema Parque Cuiabá (Rio Cuiabá) - $50 \mathrm{l} / \mathrm{s}$

\section{Captação Superficial para Várzea Grande:}

Sistema central (Rio Cuiabá), Rua Brasília Braz - $150 \mathrm{l} / \mathrm{s}$

Sistema novo (Rio Cuiabá), Guarita - 311 l/s

\section{Captação Subterrânea para Cuiabá:}

Através de 31 poços profundos em diversos bairros - 100,26 I/s

\section{Captação Subterrânea para Várzea Grande:}

Sistema de 45 poços profundos em diversos bairros - 214,71 l/s 


\section{Em Cuiabá:}

Captação superficial (Rios Cuiabá e Coxipó): 2.009 l/s

Captação subterrânea (31 poços): 100,26 I/s

Vazão total: $2.109,26 \mathrm{l} / \mathrm{s}$

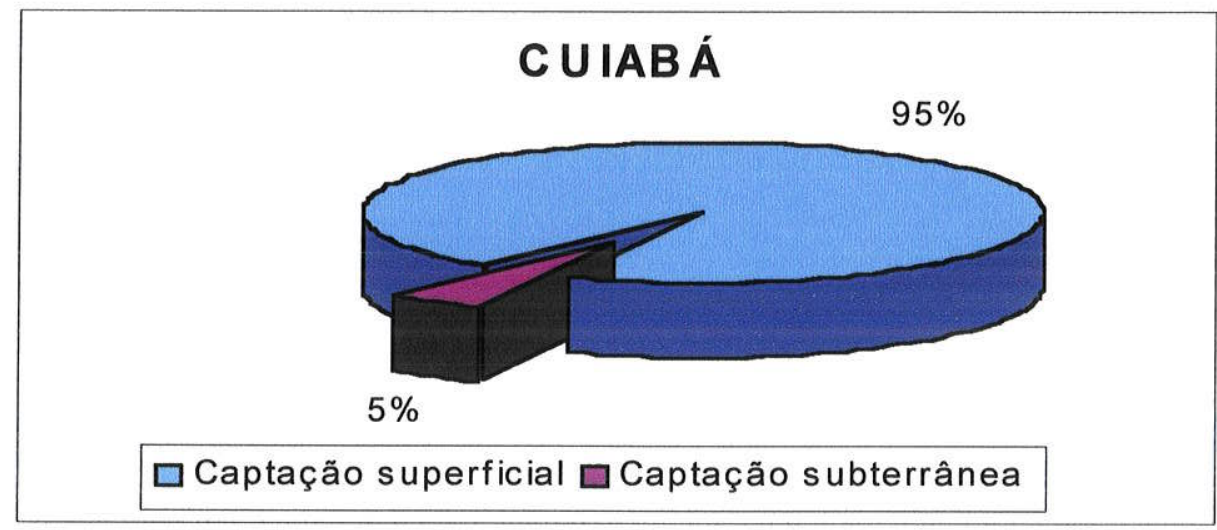

Figura 13. Captação de água superficial e subterrânea em Cuiabá. (Teixeira, 1.997).

\section{Em Várzea Grande:}

Captação superficial (Rio Cuiabá): 461,00 l/s Captação subterrânea (45 poços): 214,71 l/s Vazão total: $675,71 \mathrm{l} / \mathrm{s}$

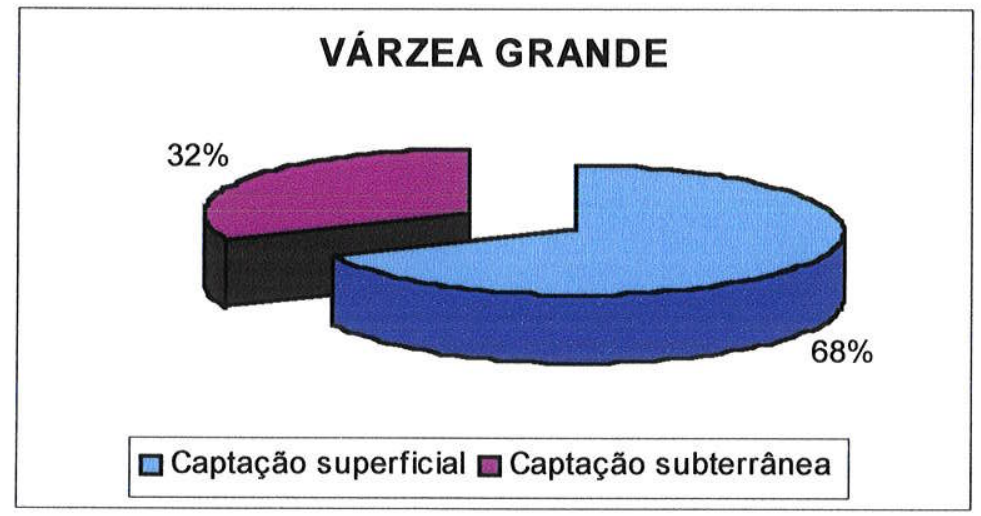

Figura 14. Captação de água superficial e Subterrânea em Várzea Grande. (Teixeira, 1.997). 
Os dados de captação dos Municípios de Cuiabá e Várzea Grande mostram que a captação superficial representa $81,5 \%$ das fontes de captação da região e o manancial subterrâneo corresponde a $18,5 \%$ das fontes captação. Entretanto, é interessante observar que nestes dados não estão incluídos as águas subterrâneas para abastecimento de hotéis, motéis, condomínios privados, clubes de lazer, hospitais, postos de gasolina, indústrias, dentre outros que, invariavelmente, possuem poços tubulares profundos em suas dependências.

\section{Tratamento para Cuiabá:}

ETA I (Pres. Marques) - $176 \mathrm{l} / \mathrm{s}$

ETA II (São Sebastião) - $1.150 \mathrm{l} / \mathrm{s}$

ETA Compacta aberta (Porto) $-112 \mathrm{l} / \mathrm{s}$

ETA (Sistema Tijucal Velho) $-112 \mathrm{l} / \mathrm{s}$

ETA (Nova Tijucal) $-410 \mathrm{l} / \mathrm{s}$

ETA Tipo SABESP (Parque Cuiabá) - $50 \mathrm{l} / \mathrm{s}$

Tratamento para Várzea Grande:

01 ETA concreto de $200 \mathrm{l} / \mathrm{s}$

03 ETAs compactas abertas de $22 \mathrm{l} / \mathrm{s}$ cada

01 ETA compacta padrăo SABESP $45 \mathrm{l} / \mathrm{s}$

01 ETA concreto $150 \mathrm{l} / \mathrm{s}$

Rede de Distribuição para Cuiabá:

$1.553,40 \mathrm{~km}$ de rede de distribuição

Rede de Distribuição para Várzea Grande:

$435,53 \mathrm{~km}$ de rede de distribuição

\subsection{2. Índice de Abastecimento de Água.}

Esses dados foram também obtidos por Teixeira (1997). 
Índice de Abastecimento de Água de Cuiabá.

População abastecida: 500.023

Taxa de ocupação: 4,24

Economias residenciais: 117.930

População urbana: 513.974

Índice de abastecimento: 97,29\%

Índice de Abastecimento de Água para Várzea Grande:

População abastecida: 186.522

Taxa de ocupação: 4,56

Economias residenciais: 40.904

População urbana: 190.374

Índice de abastecimento: 97,98\%

Tipos de ligações para o Abastecimento de Água em Cuiabá

Residencial:117.930

Comercial: 12.548

Industrial: 738

Público: 844

Total: 132.060

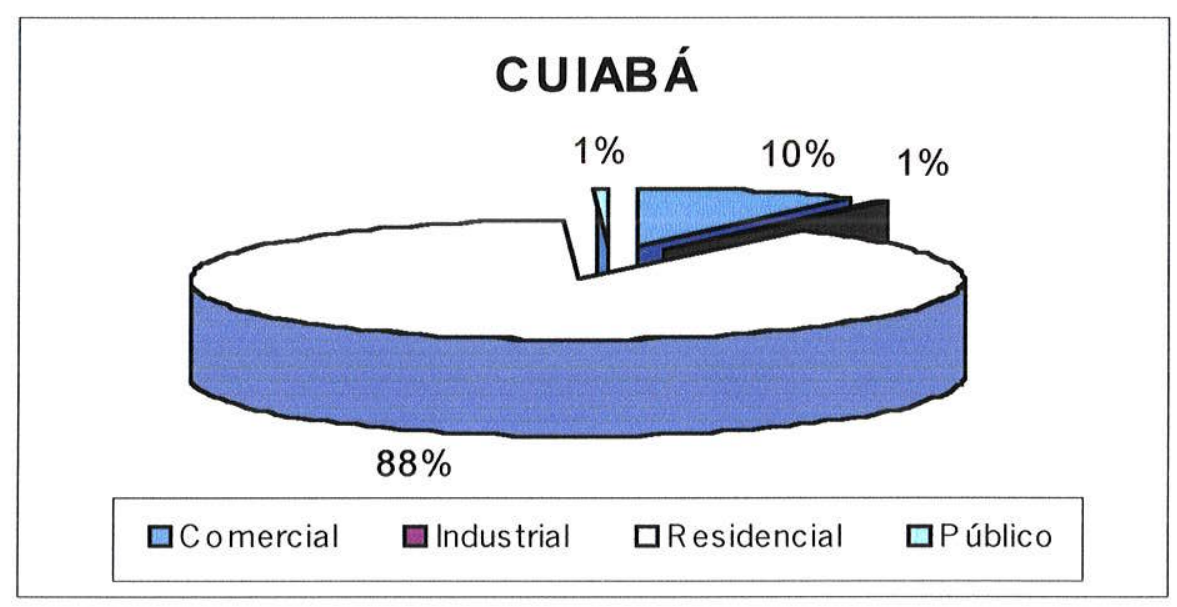

Figura 15. Tipos de ligações para o abastecimento de água em Cuiabá. (Teixeira, 1.997). 
Tipos de ligações para o Abastecimento de Água em Várzea Grande:

Residencial: 40.904

Comercial: 3.150

Industrial: 118

Público: 224

Total: 44.396

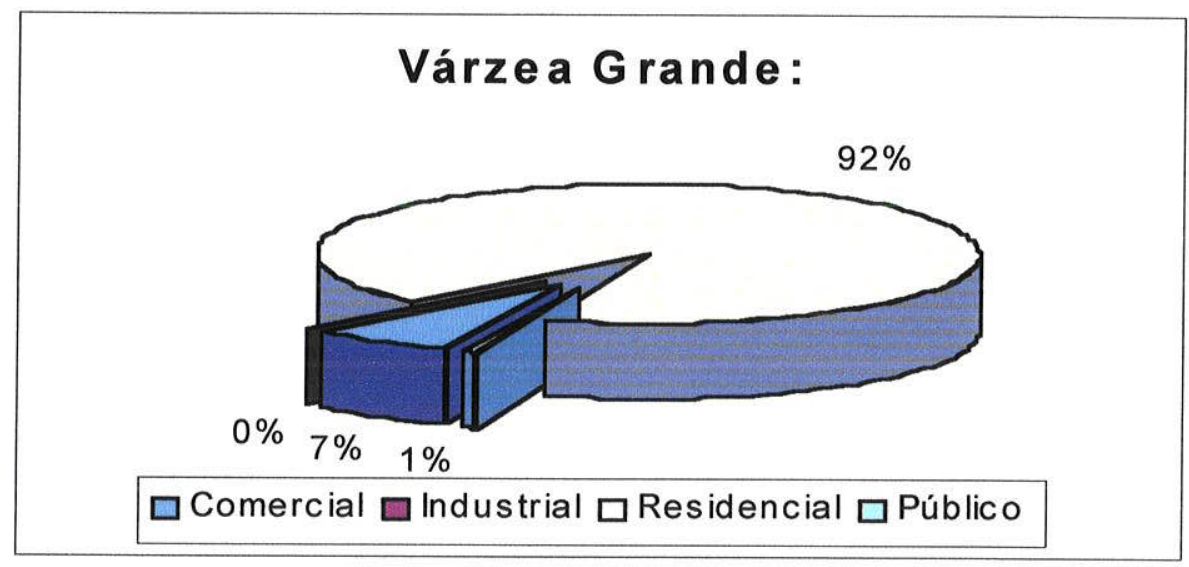

Figura 16. Tipos de ligações para o abastecimento de água em Várzea Grande. (Teixeira,1.997).

Observa-se pelas figuras que as ligações comerciais representam $8,5 \%$; as industriais, $0,5 \%$; as públicas, $1 \%$ e as residenciais, a grande maioria, com $90 \%$.

Resumindo: Em 1996, os Municípios de Cuiabá e Várzea Grande ofereceram 158.834 ligações residenciais de água, abastecendo uma população de 686.545 habitantes, apresentando um índice geral de abastecimento em torno de $97,63 \%$, que é considerado pela SANEMAT como parâmetro ideal.

\subsection{Situação do Saneamento}

Dados do Censo do IBGE de 1.991, (apud Teixeira, 1.997), a disposição de lixos e aterros sanitários de Cuiabá e Várzea Grande, está distribuída da seguinte maneira:

\section{Cuiabá:}

Total: 93.659 toneladas

Coletado: 80.959 toneladas 
Queimado: 7.120 toneladas

Enterrado: 313 toneladas

Jogado em terrenos: 4.709 toneladas

Jogado em rios: 289 toneladas

Outros: 269 toneladas

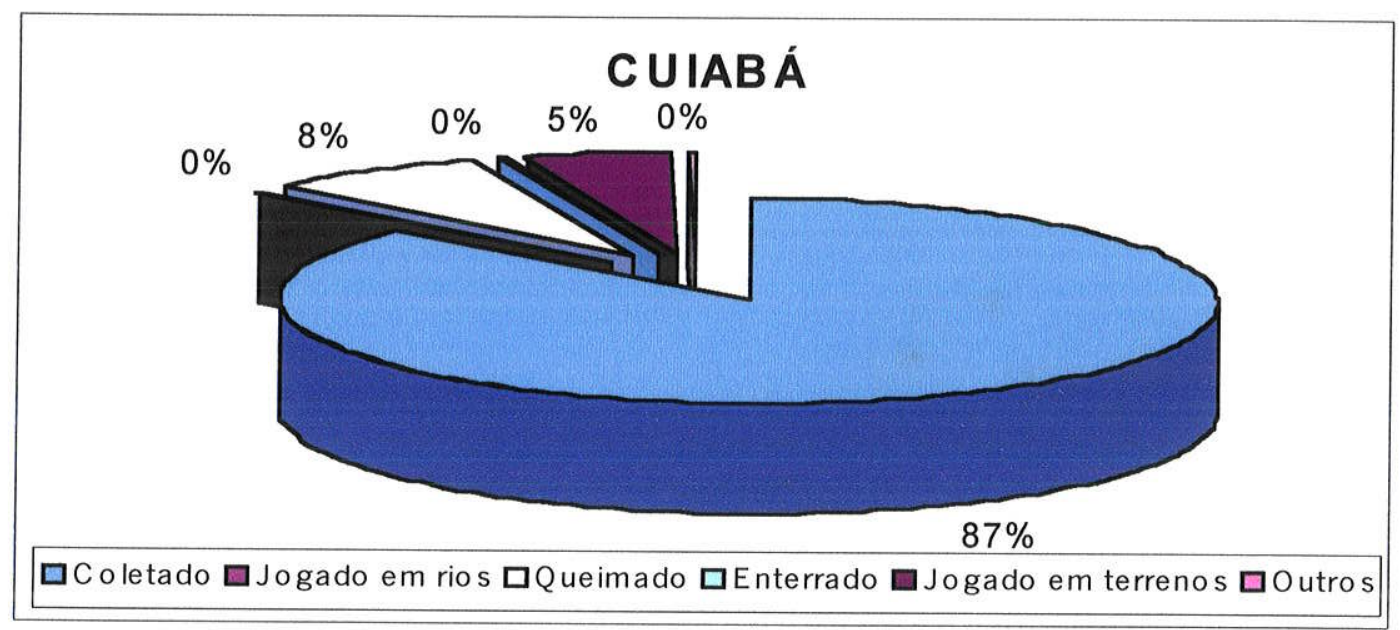

Figura 17. Distribuição de lixos e aterros sanitários de Cuiabá. (Teixeira, 1.997).

\section{Várzea Grande:}

Total: 35.360 toneladas

Coletado: 19.633 toneladas

Queimado: 9.536 toneladas

Enterrado: 195 toneladas

Jogado em terrenos: 5.790 toneladas

Jogado em rios: 53 toneladas

Outros: 153 toneladas 


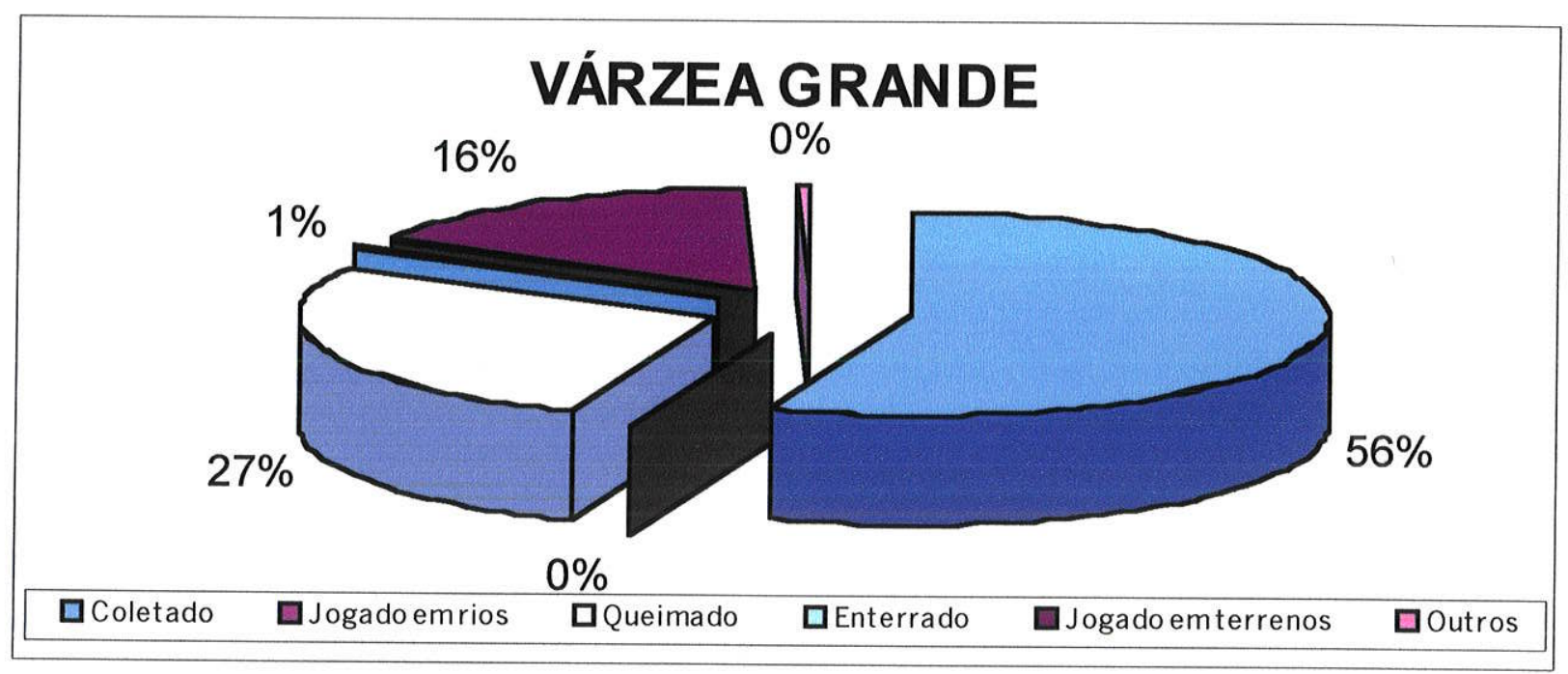

Figura 18. Distribuição de lixos e aterros sanitários de Várzea Grande. (Teixeira, 1.997).

Os dados disponíveis acima sobre a disposição de lixo e quantidade produzida nas cidades de Cuiabá e Várzea Grande mostram que o controle da disposição do lixo apresenta falhas, que podem levar a uma contaminação direta ou indireta dos recursos hídricos superficiais e subterrâneos.

No entanto, encontra-se em Cuiabá, um aterro sanitário de disposição final de lixo urbano em fase de pré-operação e uma usina de compostagem.

Observa-se em alguns bairros das duas cidades a ocupação de áreas através de invasões, ocasionando um processo de formação de favelas em locais sem nenhuma infra-estrutura, como ruas, água encanada, esgoto, energia elétrica, etc., etc. Esta ocupação indiscriminada levou alguns córregos a funcionarem como canais de esgoto, além de lixos e entulhos jogados em seu leito.

Com base em dados de Teixeira (1.997), calcula-se que cerca de $70 \%$ da poluição orgânica lançada no Rio Cuiabá seja proveniente de esgoto doméstico; que $50 \%$ do esgoto produzido na região, seja lançado em fossas sépticas e sumidouros, e o restante chega até o Rio Cuiabá através do Rio Coxipó e córregos: Prainha, Barbado, Mané Pinto e Gambá. 
Ainda segundo Teixeira (1.997), em Cuiabá, o sistema de esgotamento sanitário possui 44.792 ligações, com uma vazão coletada de $342,6 \mathrm{l} / \mathrm{s}$, dos quais apenas 67,10 I/s recebem tratamento. Ressalta, ainda, que existem 13 sistemas de esgoto sanitário construídos em bairros isolados, cujos sistemas não são operados em toda a sua capacidade por falta de ligações. Estas estações (ETEs) que poderiam tratar uma vazão de até $400 \mathrm{l} / \mathrm{s}$, são responsáveis pelo tratamento de apenas $197 \mathrm{l} / \mathrm{s}$.

Em Várzea Grande o sistema possui 2.463 ligações com uma vazão coletada de $9,30 \mathrm{l} / \mathrm{s}$, dos quais apenas 4,6 I/s recebem tratamento do tipo Lodo Ativado. (Teixeira, 1.997).

Dados do IBGE (apud Teixeira, 1.997), acusam que a estimativa da carga poluidora de origem doméstica em Cuiabá é de 29.889,65 DBO Kg/dia e em Várzea Grande é de 10.612,19 DBO Kg/dia.

\subsection{Situação dos Efluentes Industriais}

Segundo a FEMA (apud Teixeira, 1.997), a carga orgânica de origem industrial que provém dos empreendimentos potencialmente poluidores em Cuiabá e Várzea Grande são: 


\section{Cuiabá}

Tabela 09. Carga Orgânica de Origem Industrial em Cuiabá. (Teixeira, 1997).

\begin{tabular}{|c|c|c|c|c|c|}
\hline INDUSTRIA & ATIVIDADE & $\begin{array}{c}\text { TIPO DE } \\
\text { TRATAMENTO }\end{array}$ & \begin{tabular}{|c|} 
CARGA \\
REMANESCENT \\
E (KG DBO/DIA) \\
\end{tabular} & $\begin{array}{c}\text { CARGA } \\
\text { REMANESCENTE } \\
\text { ACUM. }(\%) \\
\end{array}$ & $\begin{array}{l}\text { LOCAL DE } \\
\text { LANÇAME } \\
\text { NTO }\end{array}$ \\
\hline $\begin{array}{c}\text { Cia. } \\
\text { Cervejaria } \\
\text { Cuiabana }\end{array}$ & \begin{tabular}{|c|} 
Bebidas e \\
refrigerantes
\end{tabular} & $\begin{array}{c}\text { Reator } \\
\text { anaeróbio, } \\
\text { Lagoa de } \\
\text { estabilização }\end{array}$ & $2.150,00$ & 88,78 & Rio Coxipó \\
\hline Perdigão & Oleo de soja & - & 25,00 & 99,87 & - \\
\hline $\begin{array}{c}\text { CEVAL } \\
\text { Agroindústri } \\
a\end{array}$ & $\begin{array}{c}\text { Extração de } \\
\text { óleos } \\
\text { vegetais }\end{array}$ & $\begin{array}{c}\text { Lagoas de } \\
\text { estabilização }\end{array}$ & 18,00 & 99,97 & $\begin{array}{l}\text { Rio Aricá- } \\
\text { Açu }\end{array}$ \\
\hline CEVAL & $\begin{array}{c}\text { Extração de } \\
\text { óleos } \\
\text { vegetais } \\
\end{array}$ & $\begin{array}{c}\text { Lagoas de } \\
\text { estabilização }\end{array}$ & 14,70 & 100,00 & $\begin{array}{l}\text { Córrego } \\
\text { sem nome }\end{array}$ \\
\hline $\begin{array}{l}\text { Indústria } \\
\text { Química } \\
\text { Cuiabá }\end{array}$ & $\begin{array}{c}\text { Produtos de } \\
\text { limpeza }\end{array}$ & $\begin{array}{c}\text { Aerador Lagoa } \\
\text { anaeróbica e } \\
\text { facultativa }\end{array}$ & 4,00 & - & Sumidouro \\
\hline $\begin{array}{c}\text { Sperafico da } \\
\text { Amazônia }\end{array}$ & $\begin{array}{c}\text { Esmagamen } \\
\text { to de soja }\end{array}$ & $\begin{array}{c}\text { Lagoa de } \\
\text { estabilização }\end{array}$ & 3,80 & - & $\begin{array}{c}\text { Rio Aricá- } \\
\text { Açu }\end{array}$ \\
\hline $\begin{array}{l}\text { Ind. de } \\
\text { Bebidas } \\
\text { Antárctica }\end{array}$ & \begin{tabular}{|c|} 
Bebidas $\mathrm{e}$ \\
refrigerantes
\end{tabular} & $\begin{array}{c}\text { Reator } \\
\text { anaeróbico e } \\
\text { Lagoa de } \\
\text { estabilização }\end{array}$ & $5.846,4$ & 33,55 & $\ln ^{2}$ \\
\hline $\begin{array}{l}\text { Laticínios } \\
\text { SANO }\end{array}$ & $\begin{array}{c}\text { Beneficiame } \\
\text { nto de leite }\end{array}$ & $\begin{array}{c}\text { Tanque de } \\
\text { aeração e Leito } \\
\text { de secagem }\end{array}$ & 291,8 & 97,41 & $\begin{array}{c}\text { Rio Aricá- } \\
\text { Açu }\end{array}$ \\
\hline $\begin{array}{l}\text { Rio Verde } \\
\text { Agro- } \\
\text { Indústria }\end{array}$ & \begin{tabular}{|c|}
$\begin{array}{c}\text { Extração de } \\
\text { oleos } \\
\text { vegetais }\end{array}$ \\
\end{tabular} & $\begin{array}{c}\text { Fossa séptica } \\
\text { Trat. Primário e } \\
\text { secundário }\end{array}$ & 107,0 & 99,37 & $\begin{array}{c}\text { Rio Aricá- } \\
\text { Açu }\end{array}$ \\
\hline $\begin{array}{l}\text { Difirenzi Ind. } \\
\text { de Alimentos }\end{array}$ & $\begin{array}{c}\text { Produtos } \\
\text { alimentícios }\end{array}$ & Fossa séptica & 1,00 & - & Sumidouro \\
\hline
\end{tabular}




\section{Várzea Grande}

Tabela 10. Carga Orgânica de Origem Industrial em Várzea Grande (Teixeira, 1997).

\begin{tabular}{|c|c|c|c|c|c|}
\hline Indústria & Atividade & $\begin{array}{c}\text { Tipo de } \\
\text { tratamento }\end{array}$ & $\begin{array}{c}\text { Carga } \\
\text { remanescente } \\
\text { (kgDBO/dia) }\end{array}$ & $\begin{array}{c}\text { Carga } \\
\text { remanescente } \\
\text { acum. }(\%)\end{array}$ & \begin{tabular}{|c|} 
Local de \\
lançame \\
nto
\end{tabular} \\
\hline $\begin{array}{l}\text { Cortume } \\
\text { Stephhan } \\
\text { Cia. }\end{array}$ & $\begin{array}{l}\text { Beneficiamen } \\
\text { to de couro }\end{array}$ & $\begin{array}{l}\text { Sistema em } \\
\text { implantação }\end{array}$ & $4.173,0$ & 55,50 & $\begin{array}{l}\text { Rio } \\
\text { Cuiabá }\end{array}$ \\
\hline $\begin{array}{l}\text { Sadia Oeste } \\
\text { e Agrovícola }\end{array}$ & $\begin{array}{|lr|}\text { Abate } & \text { de } \\
\text { bovinos } & \mathrm{e} \\
\text { aves } & \\
\end{array}$ & $\begin{array}{l}\text { Lagoa } \\
\text { anaeróbia e } \\
\text { facultativa }\end{array}$ & $3.300,00$ & 76,44 & \begin{tabular}{|l|} 
Rio \\
Cuiabá
\end{tabular} \\
\hline FRIVAG & $\begin{array}{l}\text { Abate de } \\
\text { bovinos }\end{array}$ & \begin{tabular}{|l|} 
Lagoa de \\
estabilização
\end{tabular} & 545,00 & 91,91 & \begin{tabular}{|l|} 
Córrego \\
Formigu \\
eiro
\end{tabular} \\
\hline Berto S/A & $\begin{array}{l}\text { Beneficiamen } \\
\text { to de couro } \\
\text { pele }\end{array}$ & \begin{tabular}{|l|} 
Fossa \\
séptica, \\
Lagoa \\
aerada \\
maturação
\end{tabular} & 386,00 & 95,80 & $\begin{array}{l}\text { Córrego } \\
\text { Formigu } \\
\text { eiro, Rio } \\
\text { Cuiabá }\end{array}$ \\
\hline FRIGOPAN & $\begin{array}{l}\text { Abate de } \\
\text { bovinos }\end{array}$ & $\begin{array}{l}\text { Lagoa de } \\
\text { estabilização }\end{array}$ & 280,00 & 98,76 & $\begin{array}{l}\text { Córrego } \\
\text { Embauv } \\
\text { al }\end{array}$ \\
\hline $\begin{array}{l}\text { Refrigerante } \\
\text { do Noroeste }\end{array}$ & Refrigerantes & $\begin{array}{ll}\text { Lagoa } \\
\text { aeração }\end{array}$ & 215,00 & 94,13 & $\begin{array}{l}\text { Rio } \\
\text { Cuiabá }\end{array}$ \\
\hline $\begin{array}{l}\text { Refrigerante } \\
\text { União S/A }\end{array}$ & Refrigerantes & $\begin{array}{l}\text { Lagoa de } \\
\text { estabilização }\end{array}$ & 34,20 & 99,57 & $\begin{array}{l}\text { Córrego } \\
\text { Embauv } \\
\text { al }\end{array}$ \\
\hline COMAJUL & $\begin{array}{l}\text { Beneficiamen } \\
\text { to de leite }\end{array}$ & $\begin{array}{l}\text { Filtro } \\
\text { anaeróbio }\end{array}$ & 28,20 & 99,73 & \begin{tabular}{|l|} 
Rio \\
Cuiabá \\
\end{tabular} \\
\hline
\end{tabular}


Os dados de carga orgânica de origem industrial proveniente dos empreendimentos potencialmente poluidores em Cuiabá e Várzea Grande mostram que pode haver uma contaminação direta ou indireta dos recursos hídricos superficiais e subterrâneos.

\subsection{Situação das Praias}

Os rios Cuiabá e Coxipó, durante a época da seca, formam várias praias, as quais são utilizadas pela população como lazer e recreação. Todavia, muitas dessas praias, sobretudo as próximas a Cuiabá, como Coophamil, Santa Isabel, Grande, Náutico, Coxipó do Ouro, Tijucal e Ponte de Ferro, encontram-se contaminadas por coliformes devido ao lançamento de esgotos domésticos (Teixeira, 1997). 


\section{POÇOS TUBULARES: estudo dos relatórios técnicos}

Nesta parte do trabalho apresentamos um estudo dos relatórios técnicos dos poços tubulares.

\subsection{Metodologia}

Num primeiro momento deste estudo, foram realizadas várias visitas às Firmas Perfuradoras de Poços Tubulares Profundos com o propósito de adquirir os relatórios técnicos. Isto porque não existe em Cuiabá um Órgão Governamental que organize esses dados. Este trabalho foi extremamente árduo e desgastante, uma vez que algumas Firmas não se mostraram dispostas e interessadas em fornecê-los e, outras, nem sequer os possuíam. Embora encontra-se tramitando na Assembléia Legislativa de Cuiabá um projeto de lei que regularize essa situação, não existe, até o momento uma legislação que estimule ou obrigue as empresas de perfuração a registrar as informações obtidas durante as perfurações.

Num segundo momento deste capítulo, apresentamos um Banco de Dados (Programa ACCESS 2.0, Anexo 05), realizado a partir dos relatórios técnicos dos poços tubulares profundos, contendo as seguintes informações:

a) Identificação dos poços tubulares profundos: código do poço, município, bairro, local, proprietário, companhia perfuradora, ano de perfuração, observações;

\section{b) Perfil geológico;}

c) Análises físico-químicas, químicas e bacteriológicas: código do poço, data da coleta e análise, turbidez, cor, $\mathrm{pH}$, alcalinidade $\left(\mathrm{OH}, \mathrm{CO}_{3}^{-}, \mathrm{HCO}_{3}{ }^{-}\right), \mathrm{CO}_{2}$ livre, dureza (total, permanente, temporária), nitrogênio amoniacal, nitrogênio de nitrito, fosfato, ferro, cálcio, cloreto, oxigênio consumido, coliforme total, coliforme fecal;

d) Características do aqüífero e dos poços tubulares profundos: código do poço, condição do aqüífero, litologia, nível estático, nível dinâmico, rebaixamento, vazão, 
vazão específica e os parâmetros hidráulicos (transmissividade do condutor hidráulico, abertura média das fraturas, condutividade hidráulica, permeabilidade e porosidade do condutor hidráulico).

e) Características construtivas e coordenadas geográficas dos poços tubulares profundos: código do poço, altitude, coordenadas geográficas (longitude e latitude), profundidade do poço, revestimento, diâmetro de perfuração.

Todos os poços tubulares profundos cadastrados foram plotados em um mapa das regiões metropolitanas de Cuiabá e Várzea Grande (Anexo 03).

Vale ressaltar, que nem todos os relatórios estavam completos, por esse motivo, alguns poços encontram-se com parâmetros em branco no Banco de Dados.

Nos poços que possuiam testes de bombeamento, os parâmetros hidráulicos do aqüífero, ou melhor dizendo, do condutor hidráulico (conjunto poço-blocos-fendas associados), foram interpretados a partir do modelo de dimensão fractal para aqüífero fissural proposto por Manoel Filho, 1996. Isto porque, os dados dos testes de bombeamento dos poços das regióes de Cuiabá e Várzea Grande encontrados nos arquivos das companhias perfuradoras, revelaram, na sua maior parte, que as vazões bombeadas não são constantes, chegando a apresentar diferenças muito grande entre a descarga inicial e a final do bombeamento, o que é comum ocorrer em poços perfurados em rochas fraturadas.

O tratamento e a interpretação dos dados obtidos através dos ensaios de bombeamento em meio fraturado pelo método de dimensão fractal podem ser feitos usando qualquer programa de análise matemática que inclua gráficos, polinômios, funções de estatística e métodos de ajuste de curvas (Manoel Filho, 1996). Neste trabalho foi utilizado o programa científico da Microsoft EXCEL 97. 


\subsection{Resultados}

Dos 400 poços tubulares profundos, construídos em 1964, 1968, e de 1973 a 1997 registrados no Banco de Dados (Anexo 04) e plotados em mapa (Anexo 03), foram obtidos os seguintes resultados:

\section{a) Características dos Poços}

A análise estatistica das caracteristicas dos poços tubulares perfurados nas regióes de Cuiabá e Várzea Grande, cadastrados no Banco de Dados, forneceu os parâmetros condensados na tabela 07.

Tabela 11. Parâmetros Estatísticos das Características dos Poços.

\begin{tabular}{|l|l|l|l|l|l|l||}
\hline $\begin{array}{l}\text { PARÁMET } \\
\text { RO }\end{array}$ & $\begin{array}{l}\text { PROF. DOS } \\
\text { POÇOS (M) }\end{array}$ & N. E. (M) & N.D. (MTS) & S (MTS) & Q (M3/H) & $\begin{array}{l}\text { C.E. } \\
\left(M^{3} / \mathrm{H} / \mathrm{M}\right)\end{array}$ \\
\hline $\begin{array}{l}N^{\circ} \text { Total de } \\
\text { Poços }\end{array}$ & 399 & 297 & 288 & 288 & 299 & 286 \\
\hline Média & 121 & 9 & 55 & 46 & 13,7 & 0,52 \\
\hline Variáncia & 913 & 45 & 543 & 551 & 202 & 0,59 \\
\hline $\begin{array}{l}\text { Desvio } \\
\text { Padrão }\end{array}$ & 30 & 7 & 23 & 23 & 14 & 0,77 \\
\hline Mediana & 115 & 7,8 & 50 & 42,3 & 10 & 0,25 \\
\hline Máximo & 300 & 46 & 139 & 129 & 113 & 5,6 \\
\hline Mínimo & 50 & 0 & 6 & 4 & 0 & 0 \\
\hline Moda & 100 & 12 & 50 & 48 & 12 & 0,27 \\
\hline$<$ Média & $59 \%$ & $58 \%$ & $56 \%$ & $55 \%$ & $69 \%$ & $70 \%$ \\
\hline > Média & $41 \%$ & $42 \%$ & $44 \%$ & $45 \%$ & $31 \%$ & $30 \%$ \\
\hline
\end{tabular}

Profundidade dos Poços

N.E.: Nível Estático;

N.D.: Nivel Dinâmico;

$S:$ Rebaixamento;

Q: Vazão;

C.E.: Capacidade Especifica. 


\section{Profundidade dos Poços}

Dos 399 poços cadastrados nas regiões de Cuiabá e Várzea Grande as profundidades variam de 50 a $300 \mathrm{~m}$. Tem média de $121 \mathrm{~m}$ e mediana de $115 \mathrm{~m}$. O valor modal é de $100 \mathrm{~m}$ e $59 \%$ dos poços tem profundidade menor que a média. Observa-se que a profundidade de $81 \%$ dos poços varia entre 50 e $150 \mathrm{~m}$.

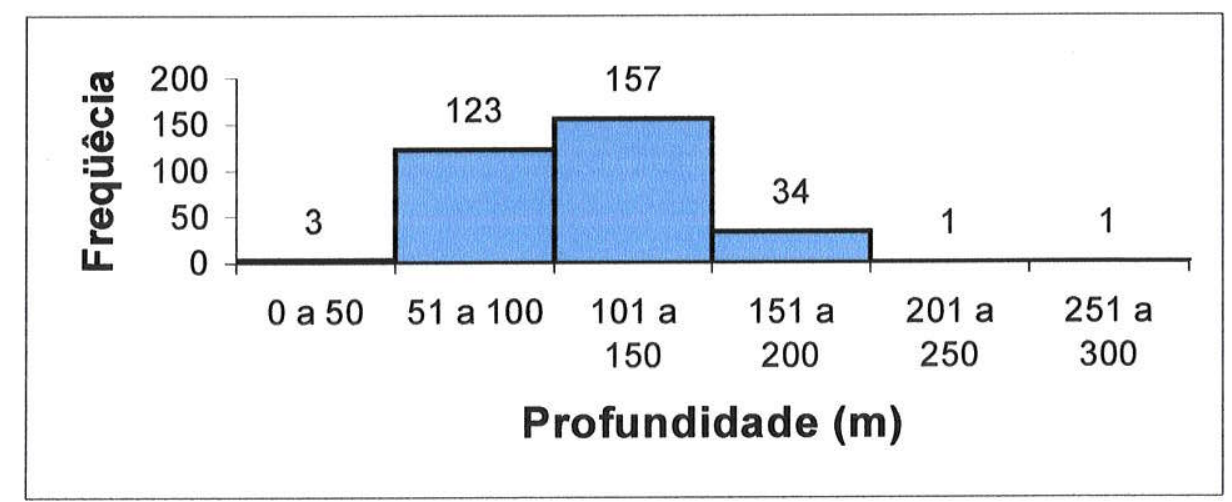

Figura 19. Profundidade dos Poços

\section{Nível Estático dos Poços}

A profundidade do nível de saturação das águas subterrâneas varia entre 0 a 46 $\mathrm{m}$, com média de $9 \mathrm{~m}$ e mediana de $8 \mathrm{~m}$. Porém $58 \%$ dos valores são menores que a média. O valor modal é de $12 \mathrm{~m}$. A grande maioria dos poços $(88 \%)$, possui a profundidade do nível estático inferior ou igual a $15 \mathrm{~m}$, o que indica águas subterrâneas pouco profundas. 


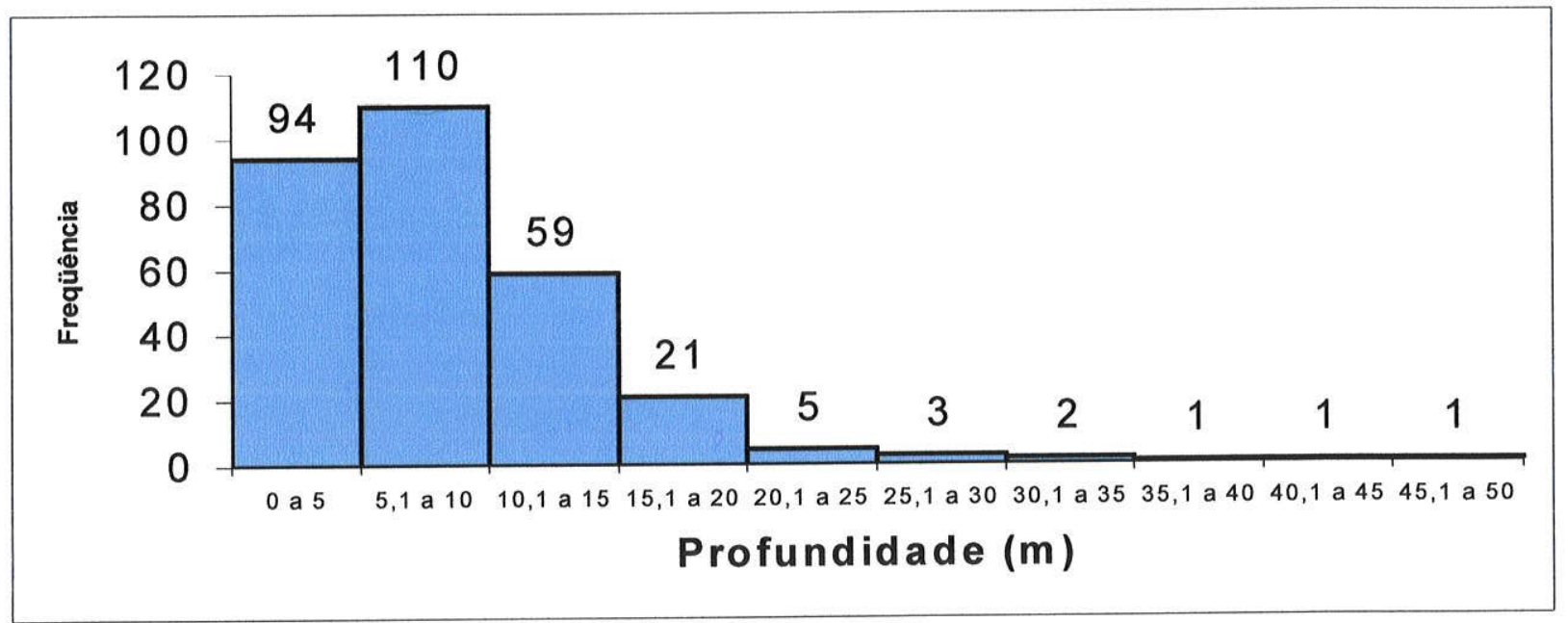

Figura 20. Nível Estático

\section{Nível Dinâmico dos Poços}

O nível dinâmico dos poços oscilaram entre 6 e 139m, com média em $55 \mathrm{~m}$ e mediana em $50 \mathrm{~m}$. Observa-se que $56 \%$ dos poços possui nível dinâmico menor que a média e que a grande maioria dos poços $(89,5 \%)$ apresentou o nível dinâmico entre 20 e $90 \mathrm{~m}$.

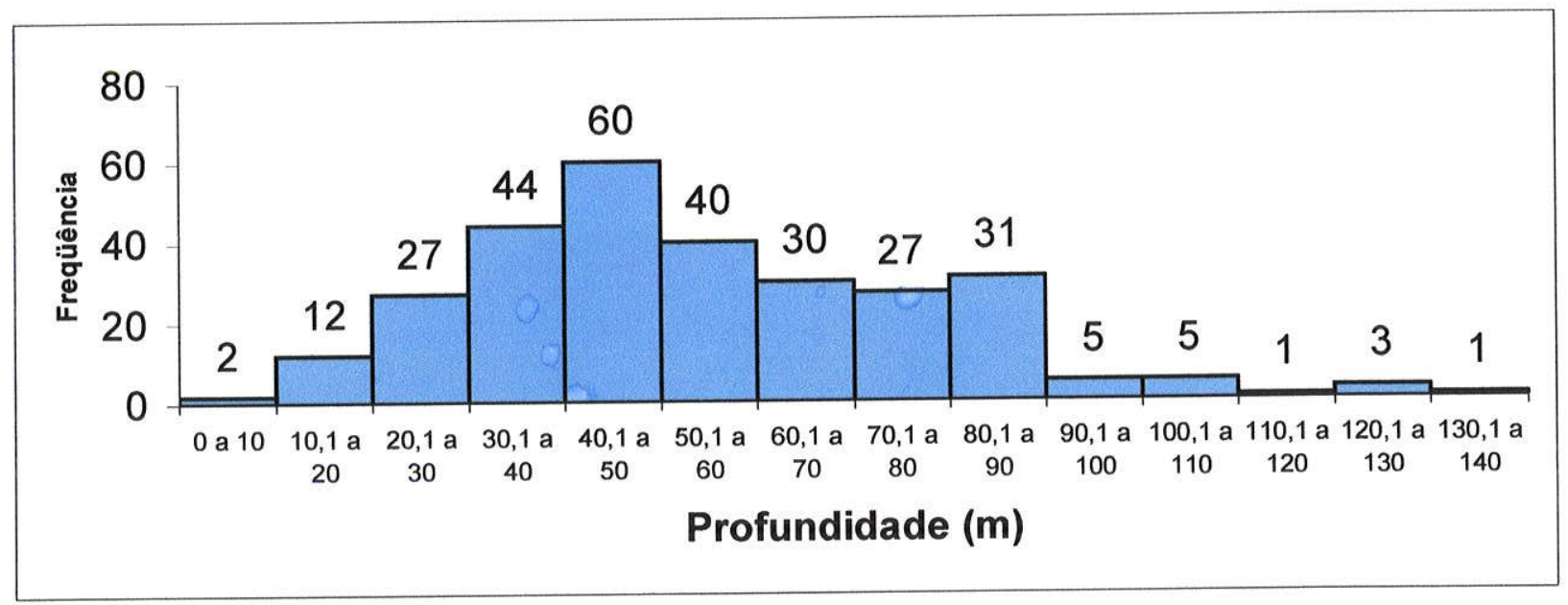

Figura 21. Nível Dinâmico 
LEGENDA:

Isolinha Piezométricas $(\mathrm{m}) \_140$

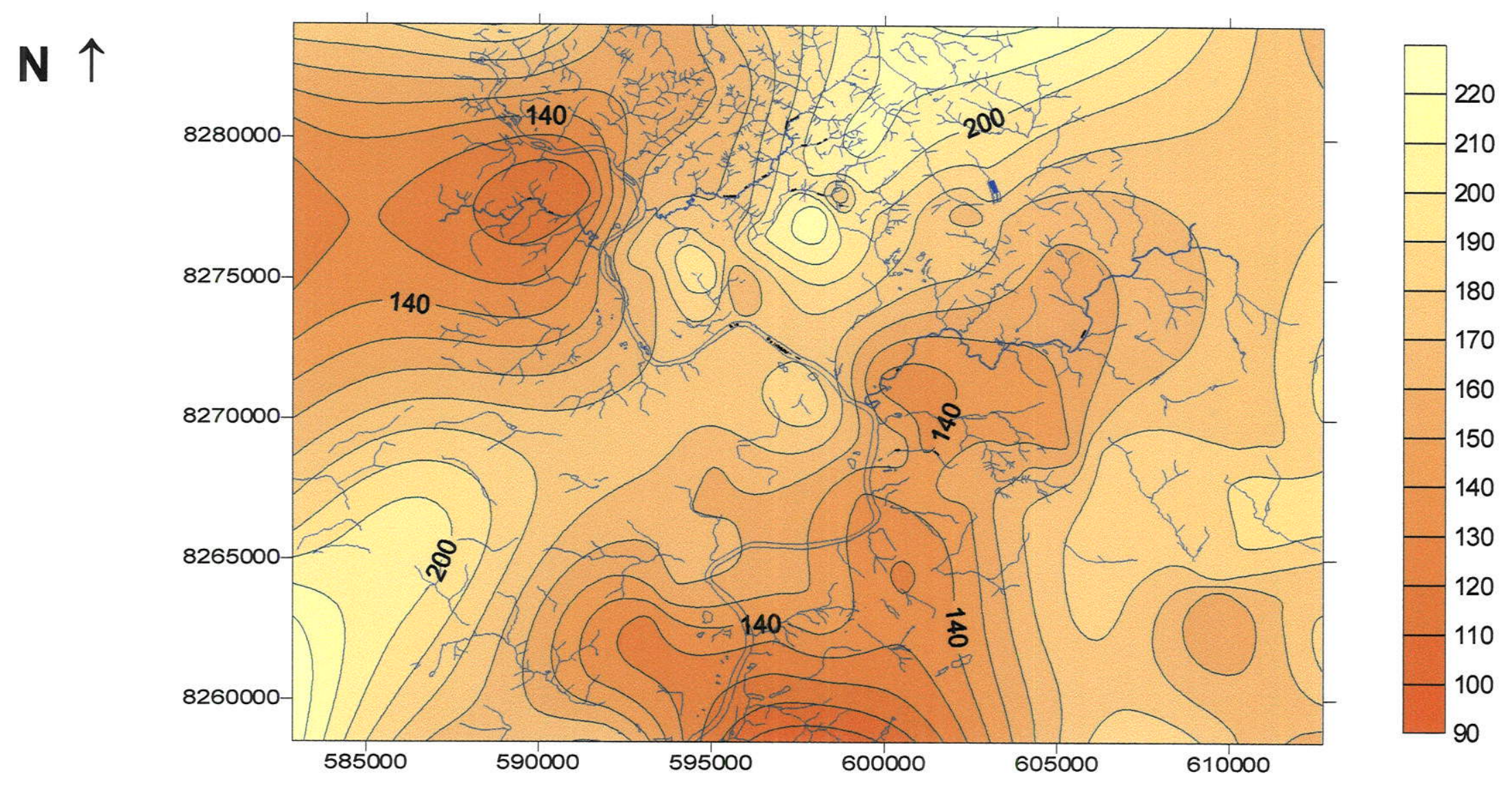

Figura 22. Mapa Potenciométrico (medidas na época de chuva: novembro, dezembro, janeiro, fevereiro, março e abril). 
LEGENDA:

Drenagens

Isolinha Piezométricas $(\mathrm{m}) \_120$

$\mathbf{N} \uparrow$

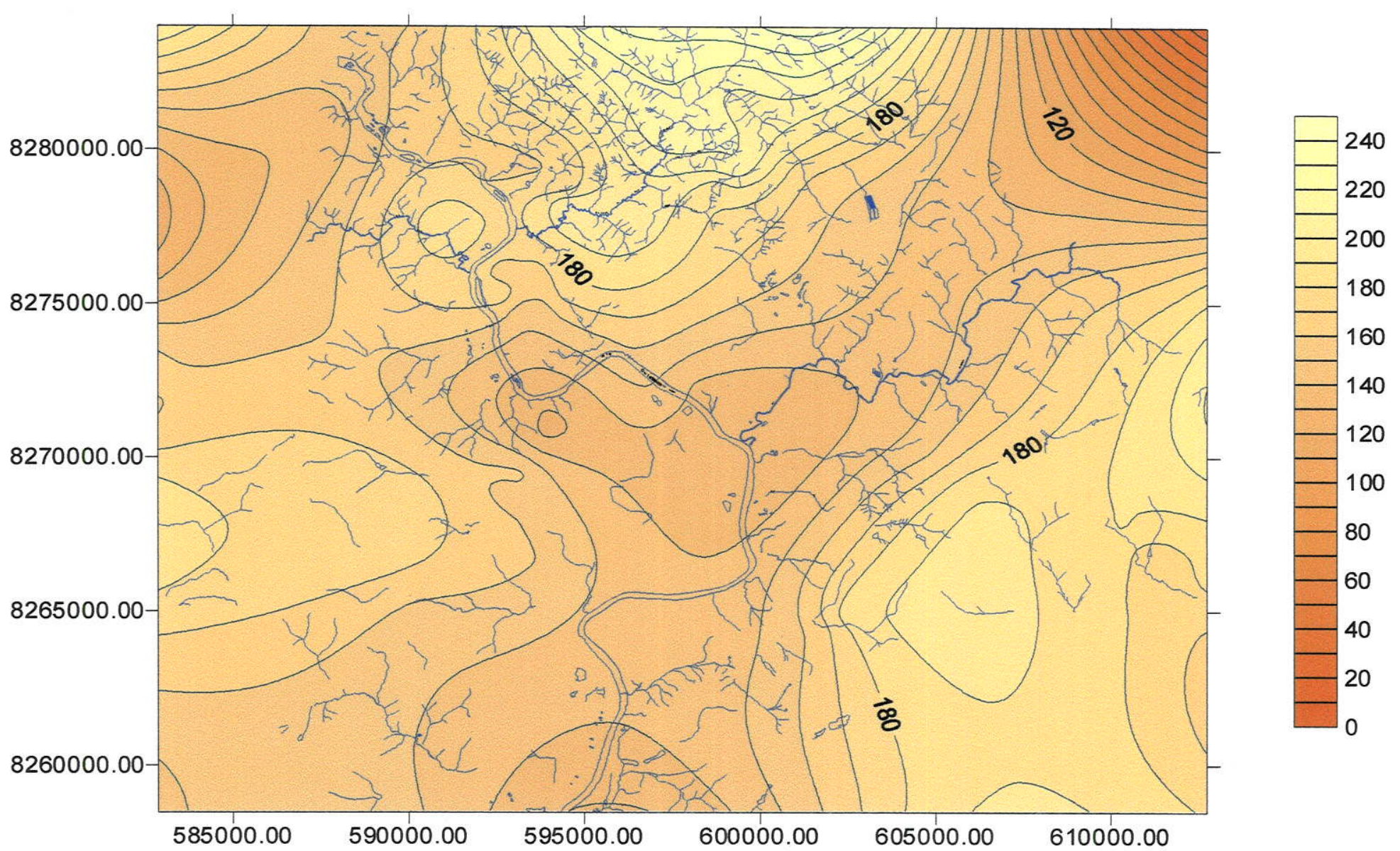

Figura 23. Mapa Potenciométrico (medidas na época de seca: maio, junho, julho, agosto, setembro e outubro). 


\section{Rebaixamento dos Poços}

O rebaixamento oscilou entre 4 e $129 \mathrm{~m}$, com média em $46 \mathrm{~m}$ e mediana de $42,3 \mathrm{~m}$. A extensa maioria dos poços (86\%) apresentou rebaixamento entre 10 e $80 \mathrm{~m}$ e $55 \%$ apresentou rebaixamento menor que a média.

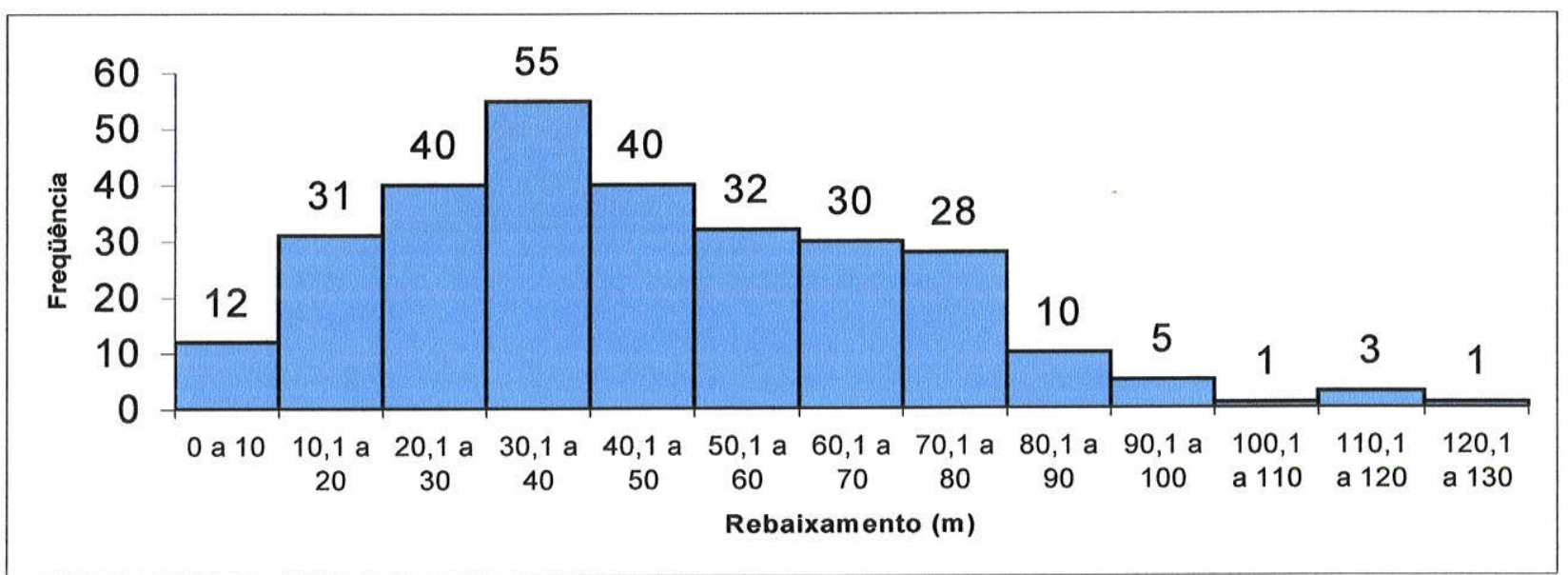

Figura 24. Rebaixamento

\section{Vazão dos Poços}

A vazão dos poços comporta-se de forma muito heterogênea, com média de $13,7 \mathrm{~m}^{3} / \mathrm{h}$ e mediana de $10 \mathrm{~m}^{3} / \mathrm{h}$. Os valores observados oscilam de poço seco a um poço com vazão excepcional para a região de $113 \mathrm{~m}^{3} / \mathrm{h}$. No entanto, a maioria dos poços $(70 \%)$, apresenta vazões inferiores ou iguais a $15 \mathrm{~m}^{3} / \mathrm{h}$ e $69 \%$ possui vazão menor que a média. 


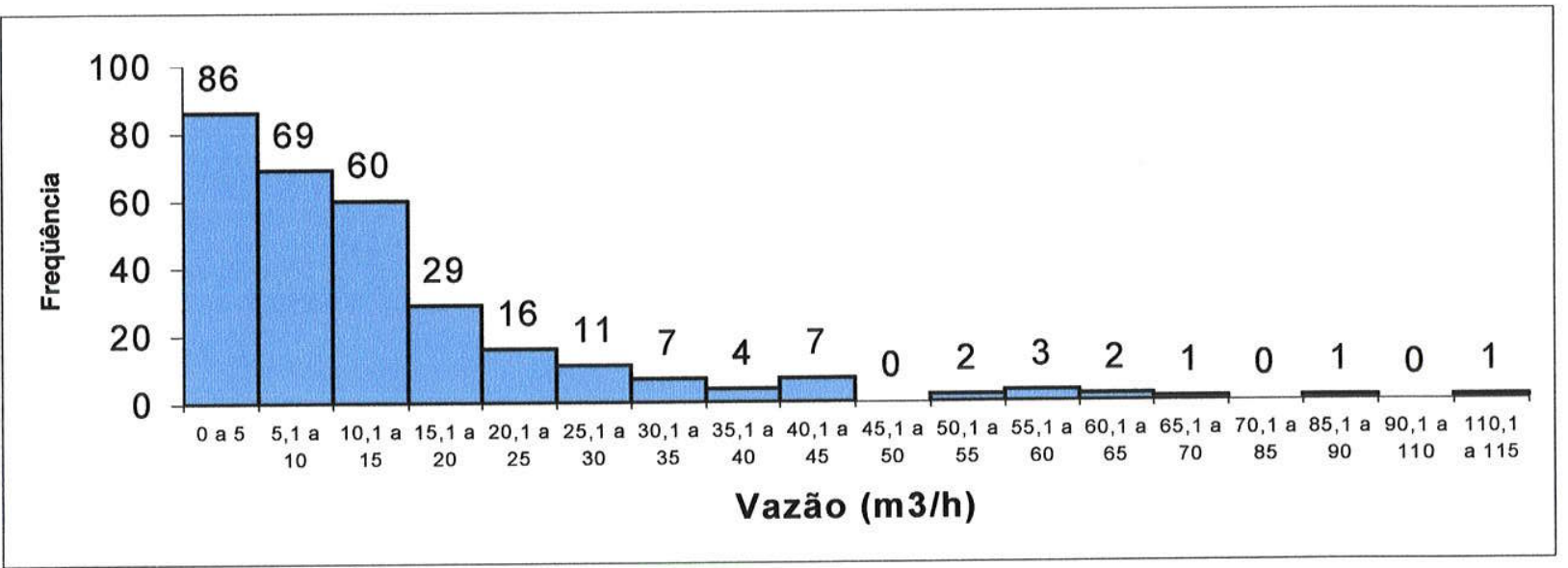

Figura 25. Vazão dos Poços

\section{Capacidade Específica dos Poços}

A capacidade específica também se comporta de forma muito heterogênea, variando de zero até $5,6 \mathrm{~m}^{3} / \mathrm{h} / \mathrm{m}$. Esta grande variação é típico de aqüífero fraturado. A média é de $0,52 \mathrm{~m}^{3} / \mathrm{h} / \mathrm{m}$ e a mediana de $0,25 \mathrm{~m}^{3} / \mathrm{h} / \mathrm{m}$. A maioria das capacidades específicas $(65,5 \%)$ é inferior ou igual a $0,5 \mathrm{~m}^{3} / \mathrm{h} / \mathrm{m}$ e $70 \%$ possui capacidade específica menor que a média.

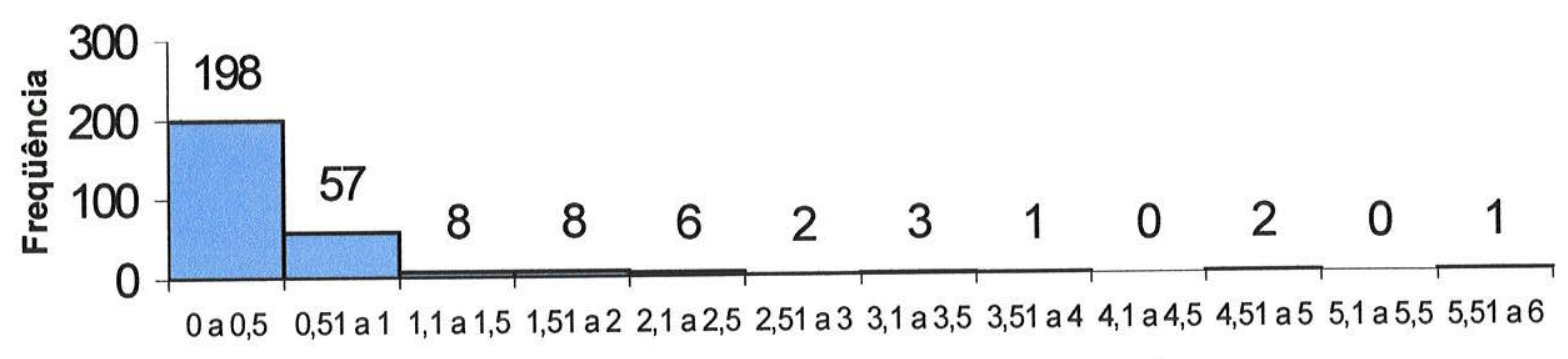

Capacidade Específica $(\mathrm{m} 3 / \mathrm{h} / \mathrm{m})$

Figura 26. Capacidade Específica 


\section{b) Produtividade do Aqüifero}

Mente \& Mont' Alverne (1982), no trabalho Mapa Hidrogeológico do Brasil na escala de 1:5.000.000, introduz a denominação produtividade de aqüifero para diferentes aqüiferos do Brasil. Esta classificação está aqui apresentada na tabela 08.

Tabela 12. Classificação de produtividade de aqüifero no Brasil (Mente\&Mont'Alverne, 1982)

\begin{tabular}{|l|l|l||}
\hline $\begin{array}{c}\text { PRODUTIVIDADE DE } \\
\text { AQÜifERO }\end{array}$ & $\begin{array}{c}\text { FAIXADE CAPACIDADE } \\
\text { ESPECIFICA PARA } \\
\text { REBAIXAMENTO DE 25 } \mathbf{~}\left(\mathbf{m}^{3} / \mathbf{h} / \mathbf{m}\right)\end{array}$ & FAIXA DE VAZÃo $\left(\mathbf{m}^{3} / \mathbf{h}\right)$ \\
\hline Muito elevada & $\mathrm{Q} / \mathrm{s}>4$ & $\mathrm{Q} / \mathrm{s}>100$ \\
\hline Média a elevada & $1<\mathrm{Q} / \mathrm{s} \leq 4$ & $25<\mathrm{Q} \leq 100$ \\
\hline Fraca a média & $0,1<\mathrm{Q} / \mathrm{s} \leq 1$ & $2,5<\mathrm{Q} \leq 25$ \\
\hline Muito fraca & $\mathrm{Q} / \mathrm{s}<0,1$ & $\mathrm{Q}<2,5$ \\
\hline
\end{tabular}

Segundo a classificação proposta por Mente \& Mont' Alverne (1.982), na região estudada, a produtividade de aqǘfero mais freqüente $(54,7 \%)$ é classificada como fraca a média. Abaixo e acima desta faixa, existem $30 \%$ de poços com produtividade muito fraca, $12,9 \%$ de poços com produtividade média a elevada e $2,4 \%$ de poços com produtividade elevada.

\section{c) Parâmetros Hidráulicos}

Como já foi mencionado na metodologia, os testes de bombeamento foram interpretados pelo método de dimensão fractal proposto por Manoel Filho (1996), já que os poços foram perfurados em meio aqülfero fissural onde a vazão é muito variável.

$\mathrm{Na}$ região estudada, a análise estatística dos parâmetros hidráulicos do meio aqüífero de 75 poços perfurados e cadastrados no Banco de Dados (anexo 01), forneceu os seguintes resultados condensados na tabela abaixo. 
Tabela 13. Parâmetros Hidráulicos

\begin{tabular}{||l|l|l|l|l|l||}
\hline PARÁMETROS & $\mathbf{T f}\left(\mathbf{m}^{2} \mathbf{l s}\right)$ & $\mathbf{a}(\mathbf{m m})$ & $\mathbf{K f}(\mathbf{m} / \mathbf{s})$ & $\mathbf{k f}\left(\mathbf{m}^{2} / \mathbf{s}\right)$ & $\mathbf{n} \mathbf{( \% )}$ \\
\hline Máximo & 0,001797 & 1,255916 & 0,083856 & 2,604579 & 0,000985 \\
\hline Mínimo & $3,13 \mathrm{E}-07$ & 0,070148 & 0,051669 & 0,008125 & $4,64 \mathrm{E}-05$ \\
\hline Média & $9,29 \mathrm{E}-05$ & 0,335888 & 0,143733 & 0,261612 & 0,000312 \\
\hline Variância & $5,99 \mathrm{E}-08$ & 0,046239 & 0,048754 & 0,161515 & $4,01 \mathrm{E}-08$ \\
\hline Desvio Padrão & 0,000245 & 0,215032 & 0,220803 & 0,40189 & 0,0002 \\
\hline Mediana & $1,90 \mathrm{E}-05$ & 0,275531 & 0,068871 & 0,125354 & 0,000234 \\
\hline Moda & $2,34 \mathrm{E}-06$ & 0,137145 & 0,017063 & 0,031056 & N/D \\
\hline > Média & $12 \mathrm{Pz}(16 \%)$ & $27 \mathrm{Pz}(36 \%)$ & $20 \mathrm{Pz}(26,6 \%)$ & $20 \mathrm{Pz}(26,6 \%)$ & $30 \mathrm{Pz}(40 \%)$ \\
\hline < Média & $63 \mathrm{Pz}(84 \%)$ & $48 \mathrm{Pz}(64 \%)$ & $55 \mathrm{Pz}(73,3 \%)$ & $55 \mathrm{Pz}(73,3 \%)$ & $45 \mathrm{Pz}(60 \%)$ \\
\hline
\end{tabular}

Tf: Transmissividade do Condutor Hidráulico

a: Abertura Média das Fraturas

Kf: Condutividade Hidráulica das Fraturas

kf: Permeabilidade das Fraturas

n: Porosidade do Condutor Hidráulico

\section{Transmissividade}

Os valores de transmissividade das fraturas apresentaram variações de $3,1 \times 10^{-}$ 7 a $1,8 \times 10^{-3} \mathrm{~m}^{2} / \mathrm{s}$, com média em $9,3 \times 10^{-5} \mathrm{~m}^{2} / \mathrm{s}$. A variância foi de $6 \times 10^{-8}$, o desvio padrão foi de $2,4 \times 10^{-4}$, a mediana foi de $1,9 \times 10^{-5} \mathrm{~m}^{2} / \mathrm{s}$ e a moda foi de $2,3 \times 10^{-6} \mathrm{~m}^{2} / \mathrm{s}$. Observa-se que (84\%) dos valores de transmissividade são menores que a média.

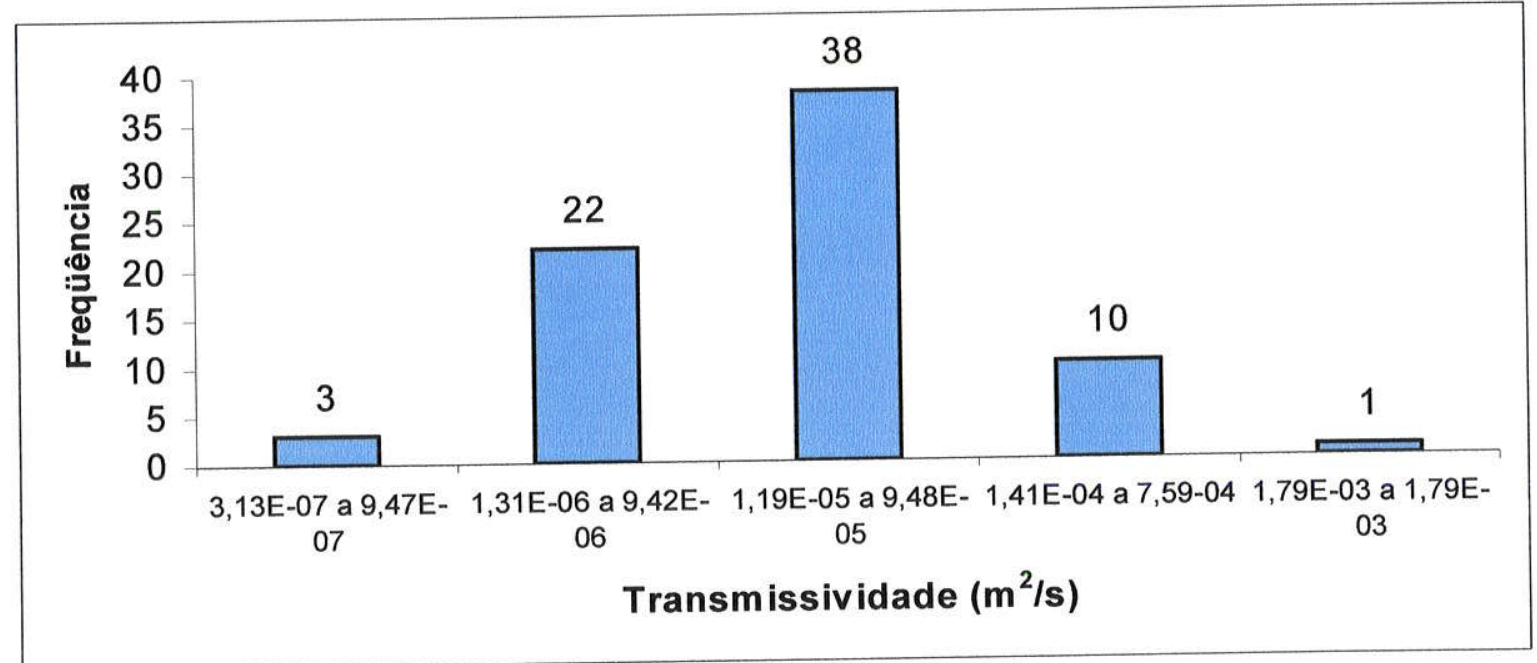

Figura 27. Transmissividade 


\section{Abertura Média das Fraturas}

A abertura média das fraturas apresentou valores de 0,07 a 1,25mm, com média em $0,33 \mathrm{~mm}$. A variância foi de 0,046 , o desvio padrão foi de 0,21 , a mediana foi de $0,27 \mathrm{~mm}$ e a moda foi de $0,13 \mathrm{~mm}$. Observa-se que, a maioria dos valores de abertura média das fraturas (64\%), foi menor que a média.

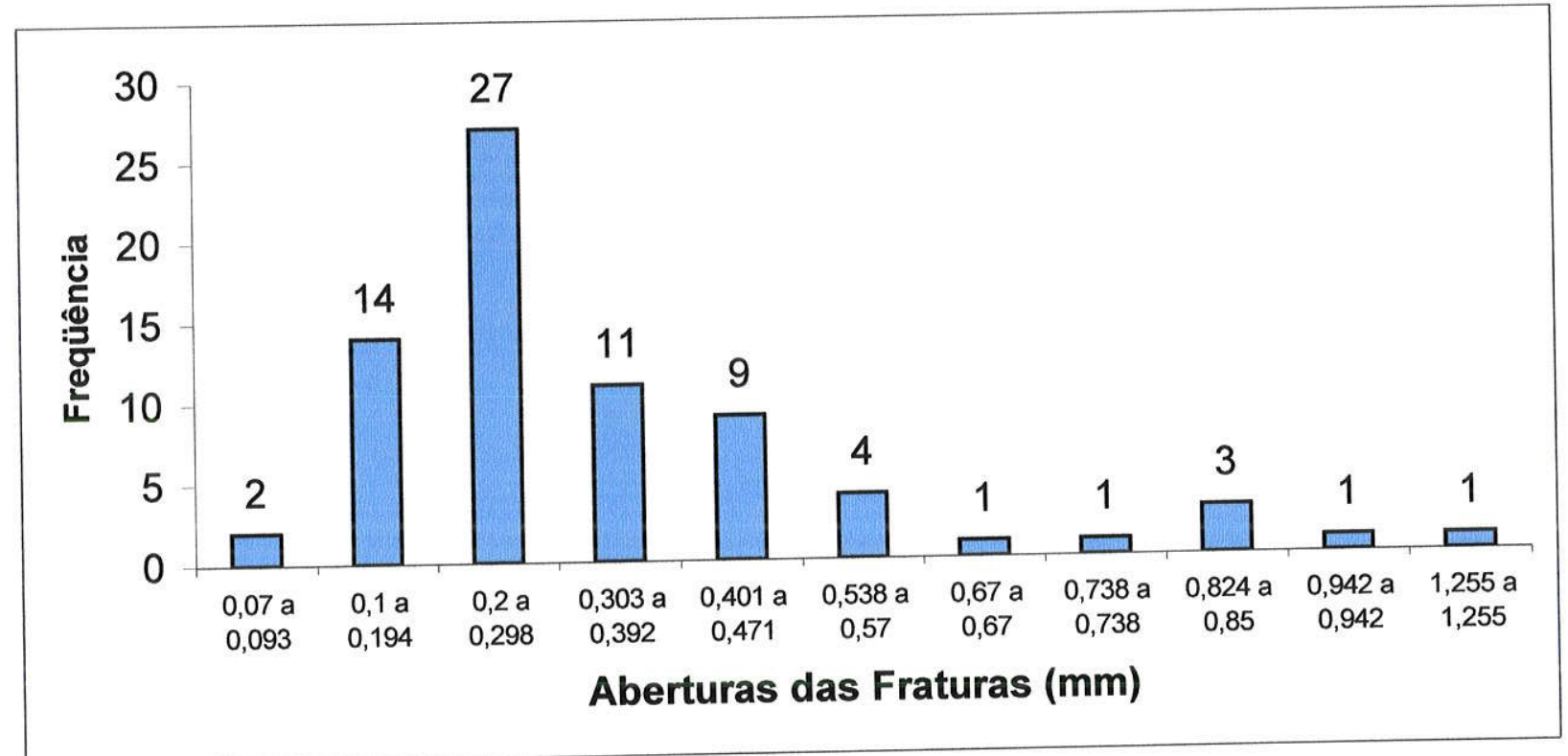

Figura 28. Abertura das Fraturas

\section{Condutividade Hidráulica}

Os valores de condutividade hidráulica das fraturas variou de 0,051 a $0,084 \mathrm{~m} / \mathrm{s}$, com média de $0,14 \mathrm{~m} / \mathrm{s}$. A variância foi de 0,048 , o desvio padrão foi de 0,22 , a mediana foi de $0,068 \mathrm{~m} / \mathrm{s}$ e a moda foi de $0,017 \mathrm{~m} / \mathrm{s}$. Nota-se que a maioria dos valores de condutividade hidráulica das fraturas $(73,3 \%)$, é menor que a média. 


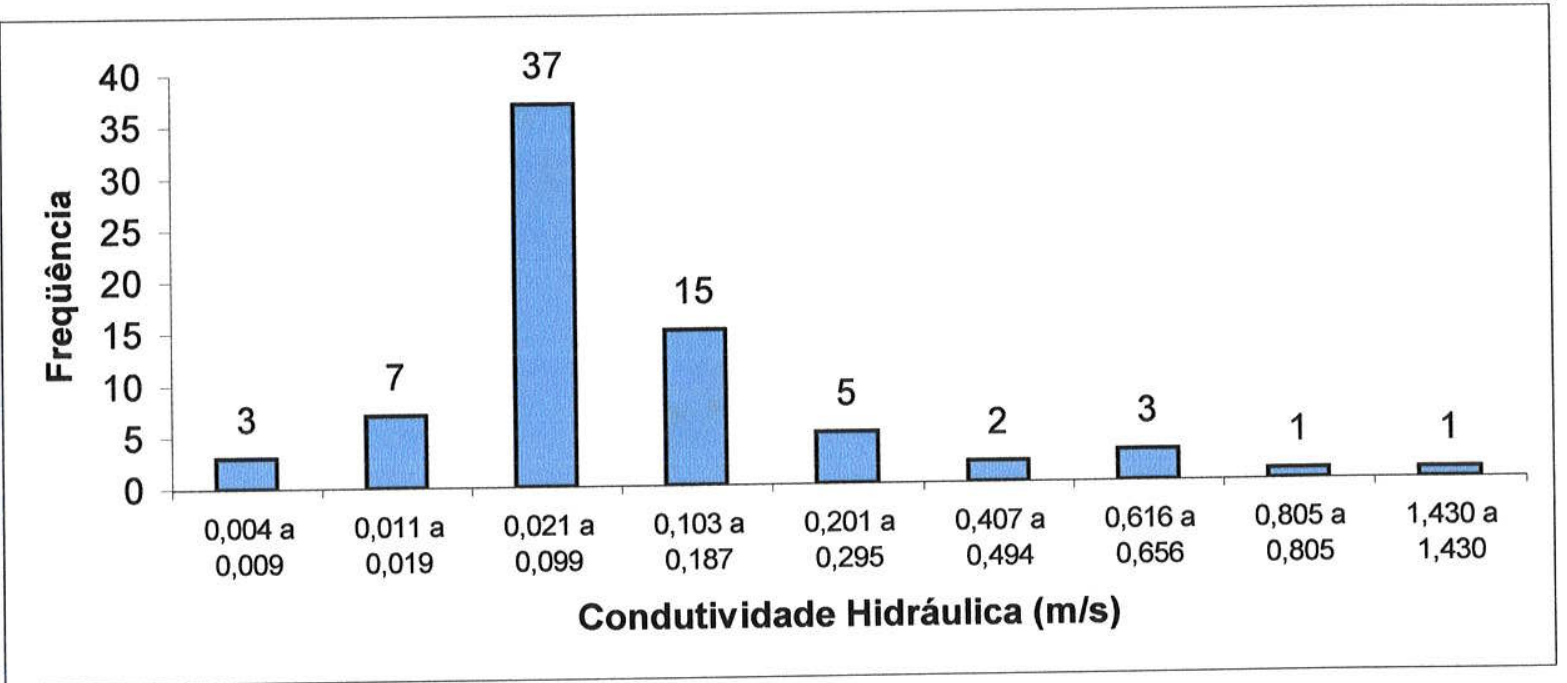

Figura 29. Condutividade Hidráulica

\section{Permeabilidade}

Os valores de permeabilidade variaram de 0,008 a $2,6 \mathrm{~m}^{2} / \mathrm{s}$, com média em $0,26 \mathrm{~m}^{2} / \mathrm{s}$. A variância foi de 0,16 , o desvio padrão foi de 0,4 , a mediana foi de $0,12 \mathrm{~m}^{2} / \mathrm{s}$ e a moda foi de $0,03 \mathrm{~m}^{2} / \mathrm{s}$. Verificou-se que a maioria dos valores de permeabilidade $(73,3 \%)$, foi menor que a média.

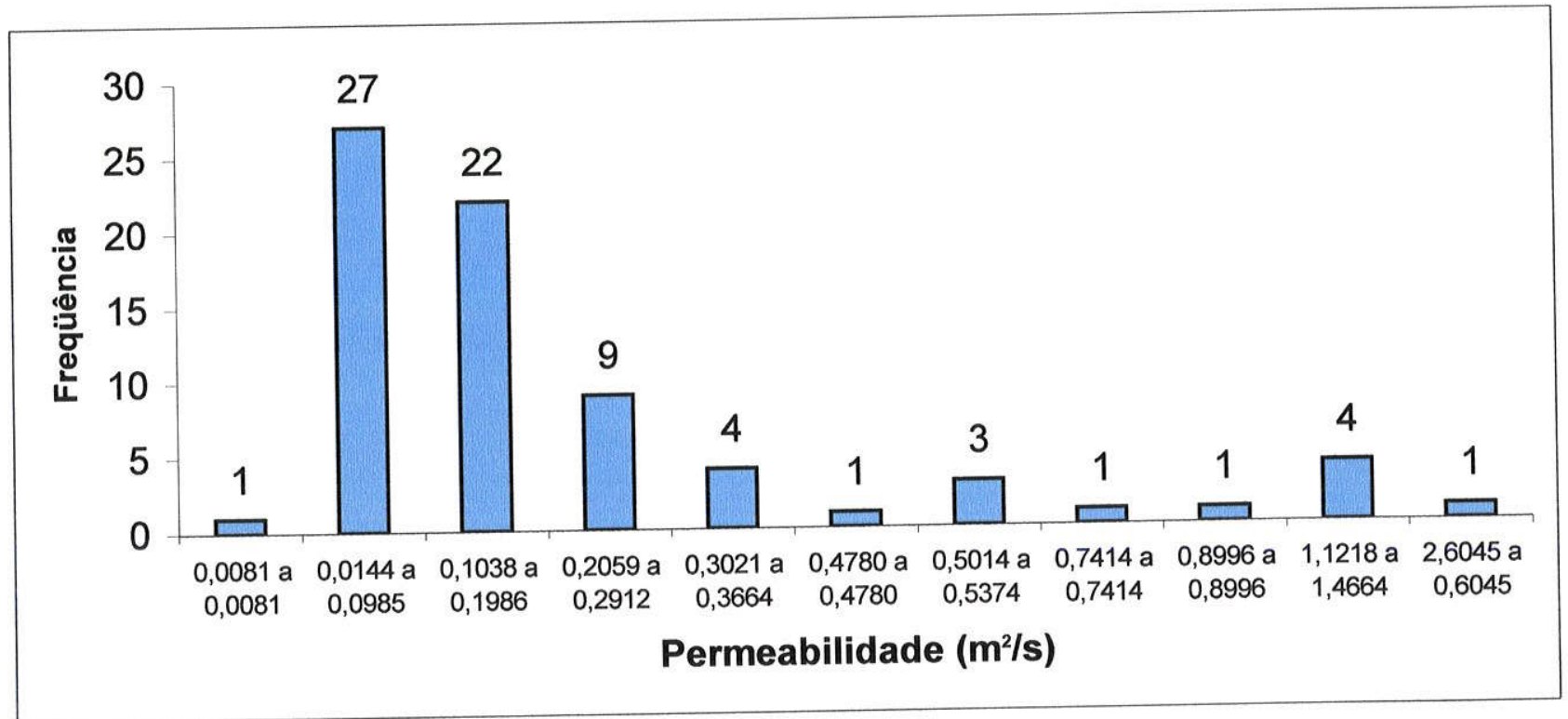

Figura 30. Permeabilidade 


\section{Porosidade}

A porosidade do condutor hidráulico variou de $4,6 \times 10^{-5}$ a $9,8 \times 10^{-4} \%$, com média em $3,1 \times 10^{-4} \%$. A variância foi de $4 \times 10^{-8}$, o desvio padrão foi de $2 \times 10^{-4}$, e a mediana foi de $2,3 \times 10^{-4}$. Constatou-se que $60 \%$ dos valores de porosidade são menores que a média.

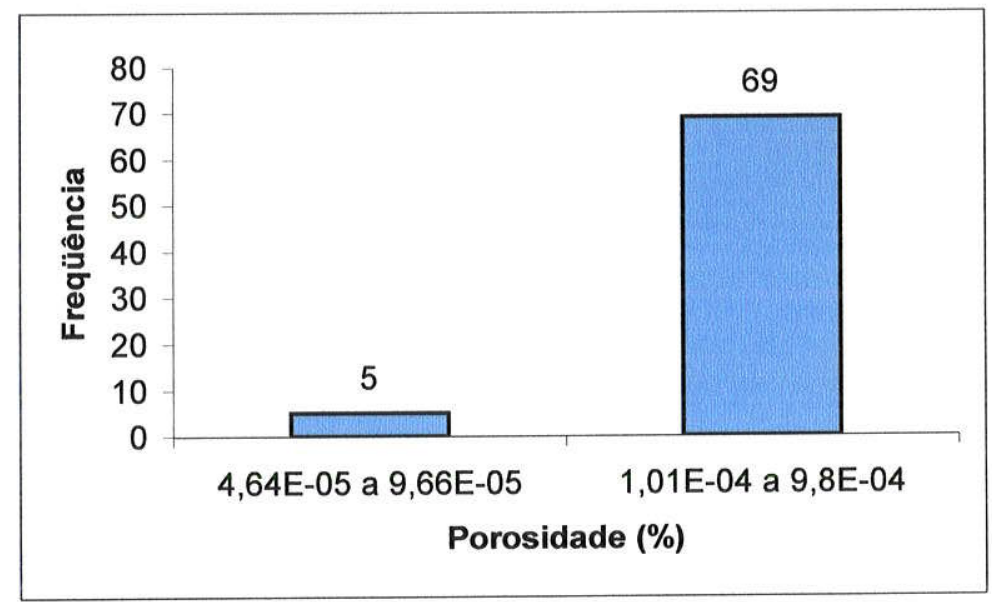

Figura 31. Porosidade

\section{d). Manto de Alteração}

A profundidade do manto de alteração foi calculada a partir dos perfis geológicos de 227 poços tubulares em anexo no Banco de Dados. A espessura do manto de alteração variou de desde a completa ausência, até um poço tubular com espessura de $105 \mathrm{~m}$ de manto de alteração. A média das profundidades do manto de alteração ficou em $29 \mathrm{~m}$, a moda em $20 \mathrm{~m}$ e a mediana em $26 \mathrm{~m}$. É interessante observar que, em 204 poços tubulares $(90 \%)$, apresentaram a profundidade do manto de alteração menor de $50 \mathrm{~m}$. 
Avenidas principais

Isolinha de espessura do manto de alteração (m)
LEGENDA: 50

$\mathbf{N} \uparrow$

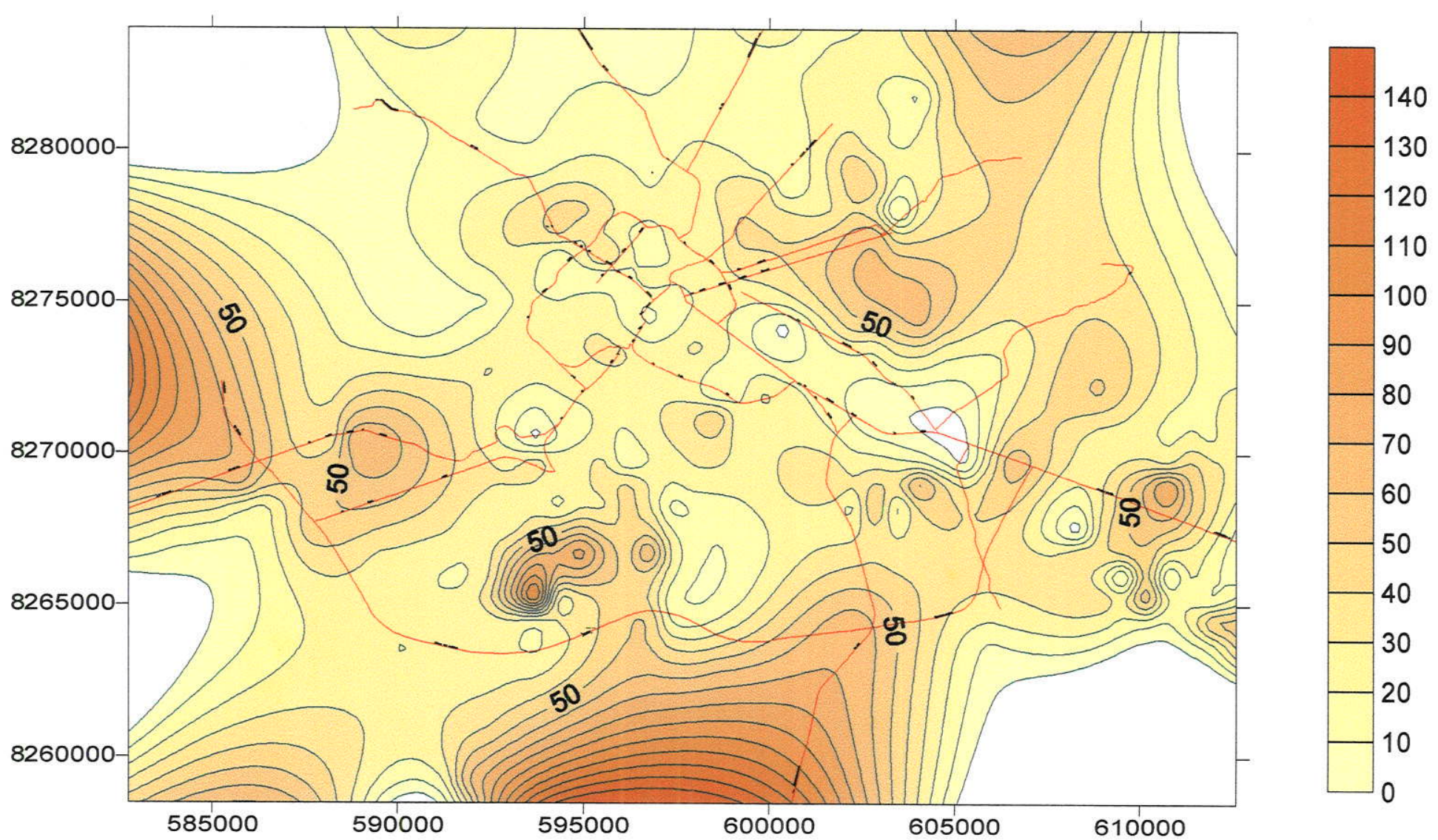

Figura 32. Mapa de Isovalores do Manto de Alteração 
Observa-se neste estudo que:

Os poços perfurados na região de Cuiabá e Várzea Grande são de pequeno porte, com profundidades em torno de 120 metros. São poços revestidos com tubos metálicos ou de plástico nas partes superiores, onde são encontradas rochas alteradas a semi alteradas, e sem revestimento nas partes mais profundas onde as rochas são duras e consolidadas. Nos poços onde o manto de alteração é mais espesso e contém água subterrânea, normalmente são colocados filtros acoplados aos revestimento para aumentar a produtividade dos poços. Poços totalmente revestidos são raros.

A profundidade do nível de saturação (nível estático), em sua grande maioria (88\%), é inferior ou igual a 15 metros, o que indica águas subterrâneas pouco profundas.

O nível dinâmico dos poços apresentou uma grande oscilação, $89 \%$ das medidas entre 20 e 90 metros. Por esta razão, a oscilação do rebaixamento também foi grande, $86 \%$ oscilou entre 10 e 80 metros.

A vazão dos poços comportou-se de forma muito heterogênea, a grande maioria (70\%), apresentou vazão menor ou igual a $15 \mathrm{~m}^{3} / \mathrm{h}$. Porém, a vazão média foi de 14 $\mathrm{m}^{3} / \mathrm{h}$, para rebaixamento médio de $46 \mathrm{~m}$. Da mesma maneira, a capacidade específica também se comportou de forma heterogênea, onde $65 \%$ são inferiores ou iguais a $0,5 \mathrm{~m}^{3} / \mathrm{h} / \mathrm{m}$. Tal comportamento já era esperado, visto que o aqüífero é fissurado, onde predomina o caráter aleatório do fraturamento e sua conseqüente imprevisibilidade. Devemos ressaltar que esses parâmetros foram calculados a partir de ensaios de bombeamento, servindo para fixar uma ordem de grandeza, porém, devemos manter algumas restrições. As observações de rebaixamento e recuperação dos níveis d'água foram feitas no próprio poço, os ensaios de bombeamento foram realizados com ar comprimido, o aqüífero é fissurado, o que muitas vezes, não permite manter uma vazão constante durante todo o ensaio.

Com relação a produtividade de aqüífero, torna-se necessário esclarecer que embora a produtividade de aqúífero seja um indicador interessante, não permite 
concluir com segurança pois a capacidade específica de poços é um parâmetro temporal. Deve-se levar este fato em conta em qualquer inferência ou conclusão sobre estes resultados. Isto posto, o Grupo Cuiabá, na região de Cuiabá e Várzea Grande, possui produtividade de aqǘfero mais freqüente $(54,7 \%)$ classificada como fraca a média, ou seja, as capacidades específicas permanecem no intervalo de 0,1 a $1 \mathrm{~m}^{3} / \mathrm{h} / \mathrm{m}$. Abaixo e acima desta faixa, existem $30 \%$ de poços com produtividade muito fraca, $12,9 \%$ de poços com produtividade média a elevada e $2,4 \%$ de poços com produtividade elevada.

Os parâmetros hidráulicos calculados a partir do modelo de dimensão fractal desenvolvido por Manoel Filho (1996), apresentaram variação muito grande no Grupo Cuiabá. Os testes revelaram que as transmissividades das fraturas variaram de $10^{-}$ ${ }^{7} \mathrm{~m}^{2} / \mathrm{s}$ a $10^{-3} \mathrm{~m}^{2} / \mathrm{s}$, as aberturas médias das fraturas variaram de $0,07 \mathrm{~mm}$ a $1,25 \mathrm{~mm}$, a condutividade hidráulica das fraturas variou de $0,051 \mathrm{~m} / \mathrm{s}$ a $0,084 \mathrm{~m} / \mathrm{s}$, os valores de permeabilidade variaram de $0,008 \mathrm{~m}^{2} / \mathrm{s}$ a $2,6 \mathrm{~m}^{2} / \mathrm{s}$ e a porosidade variou de $0,000046 \%$ a $0,00098 \%$.

A profundidade do manto de alteração é muito variável, desde a completa ausência até profundidades maiores de $100 \mathrm{~m}$. Porém, a grande maioria $(90 \%)$ dos poços possui manto de alteração com profundidade menor de $50 \mathrm{~m}$. A média é de $20 \mathrm{~m}$, a moda de $20 \mathrm{~m}$ e a mediana de $26 \mathrm{~m}$.

Verificou-se pelos Mapas Potenciométricos (Figuras 22 e 23), que as águas subterrâneas fluem das regiōes de topografia mais alta para as áreas de topografia mais baixa. Observou-se, também, que a principal área de recarga tem direção N 40-50 $\mathrm{E}$, concordante com o trend regional e que, aparentemente, coincide com a zona de charneira da antiforme invertida (Vide Mapa Geológico anexo 2). 


\section{QUALIDADE FÍSICO-QUÍMICA E BACTERIOLÓGICA DAS ÁGUAS SUBTERRÂNEAS}

Parte dos dados fornecidos a seguir foram obtidos junto ao Laboratório da Estação de Tratamento de Água da Companhia de Saneamento do Estado de Mato Grosso (SANEMAT) e parte através de análises realizadas nos Laboratórios do Departamento de Engenharia Sanitária e Ambiental da Universidade Federal de Mato Grosso (Laboratório de Análise Físico-Quimicas e Laboratório de Microbiologia Sanitária).

\subsection{Materiais e Métodos}

Neste trabalho foram utilizados os valores máximos permissiveis para o consumo humano (VMP) da Portaria N. ${ }^{\circ} 36$ / GM de janeiro de 1990 como norma padrão da potabilidade de águas destinadas ao consumo humano. Para os parâmetros que não estão limitados nesta portaria, (alcalinidades de $\mathrm{OH}, \mathrm{CO}_{3}, \mathrm{HCO}_{3}, \mathrm{O}_{2}$ consumido e $\mathrm{N}$ amoniacal) foram utilizados os VMP do Decreto Estadual N. ${ }^{0} 12.486$, de 20/10/79 (NTA 60) em anexo.

Todos os parâmetros medidos foram analisados segundo Standard Methods for the Examination of Water and Wastewater, 1985.

Procedimentos e equipamentos utilizados para as análises físico-químicas:

a) $A$ análise da turbidez foi efetuada em um turbidímetro $B 250$ da MICRONAL, Indústria Brasileira na SANEMAT e por um turbidímetro AP 1000 II da POLILAB na UFMT;

b) Para a análise da cor foi efetuada a leitura no equipamento Água Tester da HELLIGE, Indústria Brasileira na SANEMAT e pelo Aqua Nessler NA 1000 da POLILAB na UFMT; 
c) Para a análise do $\mathrm{pH}$ foi efetuada a leitura diretamente no $\mathrm{pH}$-metro da MICRONAL, Indústria Brasileira na SANEMAT e pelo pH-metro DIGIMED DM 20 na UFMT;

O mesmo método foi utilizado para as medidas abaixo:

d) Para medir a alcalinidade foi utilizado a titulação com $\mathrm{H}_{2} \mathrm{SO}_{4}, 0,02 \mathrm{~N}$;

e) $\mathrm{O}_{2}$ livre foi determinado graficamente; com base nos valores da alcalinidade total e pH;

f) Para medir a dureza (total, permanente e temporária), foi utilizado o Método de titulação com EDTA, $0,01 \mathrm{~N}$;

g) Para medir o nitrogênio amoniacal foi utilizado o método de Nessler. O equipamento utilizado foi: Água Tester da HELLIGE, Indústria Brasileira;

h) Para medir o nitrogênio de nitrito foi utilizado o Método da Sulfanilamida. O equipamento utilizado foi um Espectrofotômetro B 280 da MICRONAL, Indústria Brasileira;

i) O ferro foi determinado pelo Método da Fenantrolina. O equipamento utilizado foi um Espectrofotômetro B 280 da MICRONAL, Indústria Brasileira;

j) O cálcio foi determinado pelo Método EDTA (titulação com EDTA 0,01 N);

k) $\mathrm{O}$ cloreto foi determinado pelo Método de $\mathrm{MHOR}$ (titulação com $\mathrm{AgNO}_{3} 0,0141 \mathrm{~N}$ );

l) $O$ oxigênio consumido foi determinado pelo Método da Oxidação com Permanganato de Potássio (titulação com pemanganato de potássio $0.0125 \mathrm{~N}$ ).

Procedimentos para as Análises Bacteriológicas:

Os coliformes fecais e coliformes totais foram detectados pelas análises bacteriológicas. As metodologias utilizadas foram a técnica dos tubos múltiplos na SANEMAT e a técnica da membrana filtrante na UFMT.

Os equipamentos utilizados foram:

- Sistema de filtração Millipore (UFMT);

- Autoclave (temperatura de $121^{\circ} \mathrm{C}$, pressão de vapor de 15 libras por polegada quadrada) da SOC. FABBE Ltda, modelo 105 (SANEMAT);

- Estufa de esterilização e secagem $\left(170\right.$ a $\left.180^{\circ} \mathrm{C}\right)$ da FANEM Ltda;

- Incubadora bacteriológica $\left(35^{\circ} \mathrm{C}\right)$; 
- Banho-maria com agitação $\left(44,5^{\circ} \mathrm{C}\right)$ da ÉTICA;

- Destilador de água da PERMUTION;

- Medidor de pH (precisão de 0,1 unidade de pH) da MICRONAL;

\subsection{Resultados}

As análises físico-químicas e bacteriológicas das águas subterrâneas nas regiões de Cuiabá e Várzea Grande, cadastradas no banco de dados (Anexo 04), forneceram os resultados resumidos na tabela 14.

Tabela 14. Qualidade da Água Subterrânea

\begin{tabular}{|c|c|c|c|c|c|}
\hline PARAMETROS & UNIDADE & VMP & $\begin{array}{c}N^{\circ} \mathrm{DE} \\
\text { ANÁLIZES } \\
\text { REALIZADAS } \\
\end{array}$ & $\begin{array}{c}\text { No DE } \\
\text { ANÁLIZES } \\
\text { DENTRO VMP } \\
\end{array}$ & $\begin{array}{c}N^{\circ} \text { DE } \\
\text { ANÁLIZES } \\
\text { FORA DO VMP } \\
\end{array}$ \\
\hline Turbidez & uT & 1 & 183 & 95 & 88 \\
\hline Cor & $\mathrm{uH}$ & 5 & 183 & 136 & 47 \\
\hline $\mathrm{PH}$ & & 6,5 a 8,5 & 184 & 165 & 19 \\
\hline $\begin{array}{l}\text { Alcalinidade } \\
\left(\mathrm{HCO}_{3}\right)\end{array}$ & $\begin{array}{c}\mathrm{Mg} / / \mathrm{Ca} \\
\mathrm{CO}_{3}\end{array}$ & 250 & 183 & 166 & 17 \\
\hline $\begin{array}{l}\text { Alcalinidade } \\
(\mathrm{OH})\end{array}$ & $\begin{array}{c}\mathrm{Mg} / \mathrm{l} \mathrm{Ca} \\
\mathrm{CO}_{3}\end{array}$ & 0 & 131 & 130 & 1 \\
\hline $\begin{array}{l}\text { Alcalinidade } \\
\left(\mathrm{CO}_{3}\right)\end{array}$ & $\begin{array}{c}\mathrm{Mg} / \mathrm{I} \mathrm{Ca} \\
\mathrm{CO}_{3}\end{array}$ & 120 & 131 & 131 & 0 \\
\hline $\mathrm{CO}_{2}$ (livre) & $\mathrm{Mg} / / \mathrm{CO}_{2}$ & * & 120 & * & * \\
\hline Dureza Total & $\begin{array}{c}\mathrm{Mg} / \mathrm{l} \mathrm{Ca} \\
\mathrm{CO}_{3}\end{array}$ & 500 & 136 & 136 & 0 \\
\hline $\mathrm{N}$ (amoniacal) & $\mathrm{Mg} / \mathrm{lN}$ & 0,05 & 114 & 109 & 5 \\
\hline $\mathrm{N}$ (nitrito) & $\mathrm{Mg} / \mathrm{N}$ & 1 & 152 & 151 & 1 \\
\hline Fosfato & $\mathrm{Mg} / \mathrm{PPO}$ & * & 146 & * & * \\
\hline Ferro & $\mathrm{Mg} / \mathrm{Fe}$ & 0,3 & 179 & 107 & 72 \\
\hline Cálcio & $\mathrm{Mg} / \mathrm{/Ca}$ & * & 170 & * & * \\
\hline Cloreto & $\mathrm{Mg} / \mathrm{l} \mathrm{Cl}$ & 250 & 171 & 171 & 0 \\
\hline $\mathrm{O}_{2}$ consumido & $\mathrm{Mg} / / \mathrm{O}_{2}$ & 10 & 157 & 156 & 1 \\
\hline $\begin{array}{l}\text { Coliformes } \\
\text { Totais }\end{array}$ & $\begin{array}{c}\text { NMP/100 } \\
\text { mg de } \\
\text { coliformes }\end{array}$ & 0 & 164 & 82 & 82 \\
\hline $\begin{array}{l}\text { Coliformes } \\
\text { Fecais }\end{array}$ & $\begin{array}{c}\text { NMP/100 } \\
\mathrm{mg} \mathrm{de} \\
\text { coliformes }\end{array}$ & 0 & 144 & 89 & 55 \\
\hline
\end{tabular}

12.436/1978).

* - Portaria não limita valores. 


\section{Turbidez}

Foram realizadas 183 análises de turbidez nas águas subterrâneas dos poços elencados no Banco de Dados. Destas, 88 encontraram-se acima dos Valores Máximos Permissíveis ao consumo humano (VMP), isto é, $48 \%$. As concentrações variaram de 0 a $100 \mathrm{uT}$, porém a grande maioria apresentou concentração entre 1 e 10 uT.

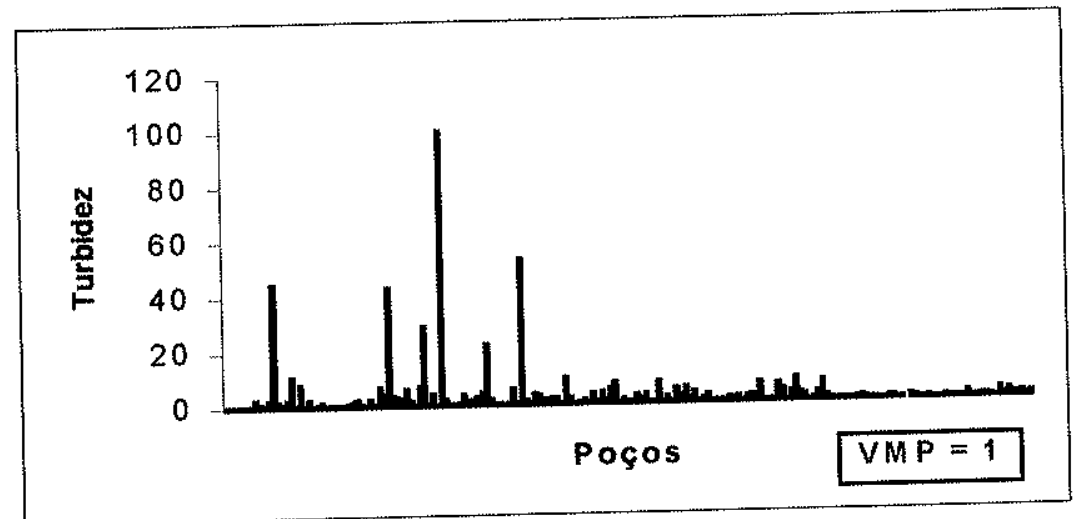

Figura 33. Turbidez

Valores estatísticos das concentrações (UT) de turbidez:

Média $=3,44$

Máximo $=100$

Mínimo $=0$

Variância $=94,75$

Desvio Padrão $=9,7$

Mediana $=0,96$

Moda $=2$

\section{Cor}

Foram realizadas 183 análises de cor, sendo que, 47 amostras (26\%) apresentaram concentração acima dos Valores Máximos Permissíveis ao Consumo 
Humano (VMP). As concentrações acima do VMP variaram de 5 a $650 \mathrm{uH}$, porém a grande maioria apresentou concentração entre 5 e 15 uH.

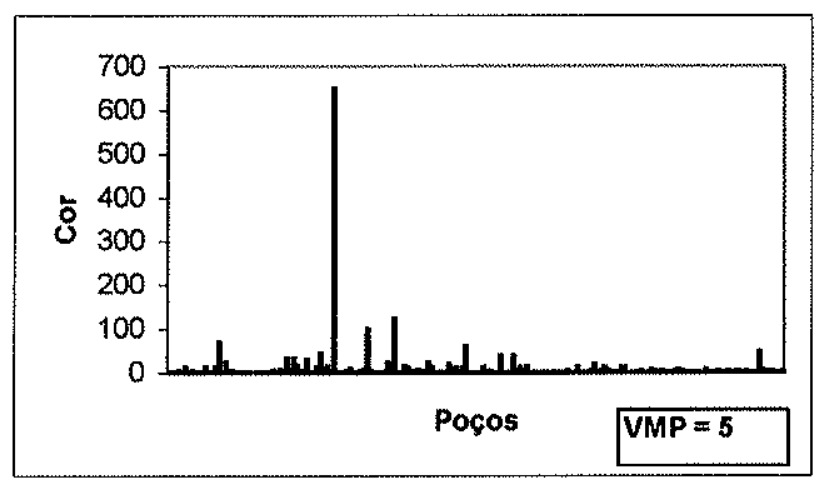

Figura 34. Cor

Valores estatísticos das concentrações $(\mathrm{uH})$ da cor:

Média $=11,6$

Máximo $=650$

Mínimo $=0$

Variância $=2477$

Desvio Padrão $=50$

Mediana $=2,5$

Moda $=2,5$

pH

Foram realizadas 184 análises de $\mathrm{pH}$, destas, $19(10 \%)$ mostraram-se fora dos Valores Máximos Permissíveis ao Consumo Humano. Somente uma das amostras apresentou $\mathrm{pH}$ ácido, o restante apresentou $\mathrm{pH}$ alcalino a neutro. 


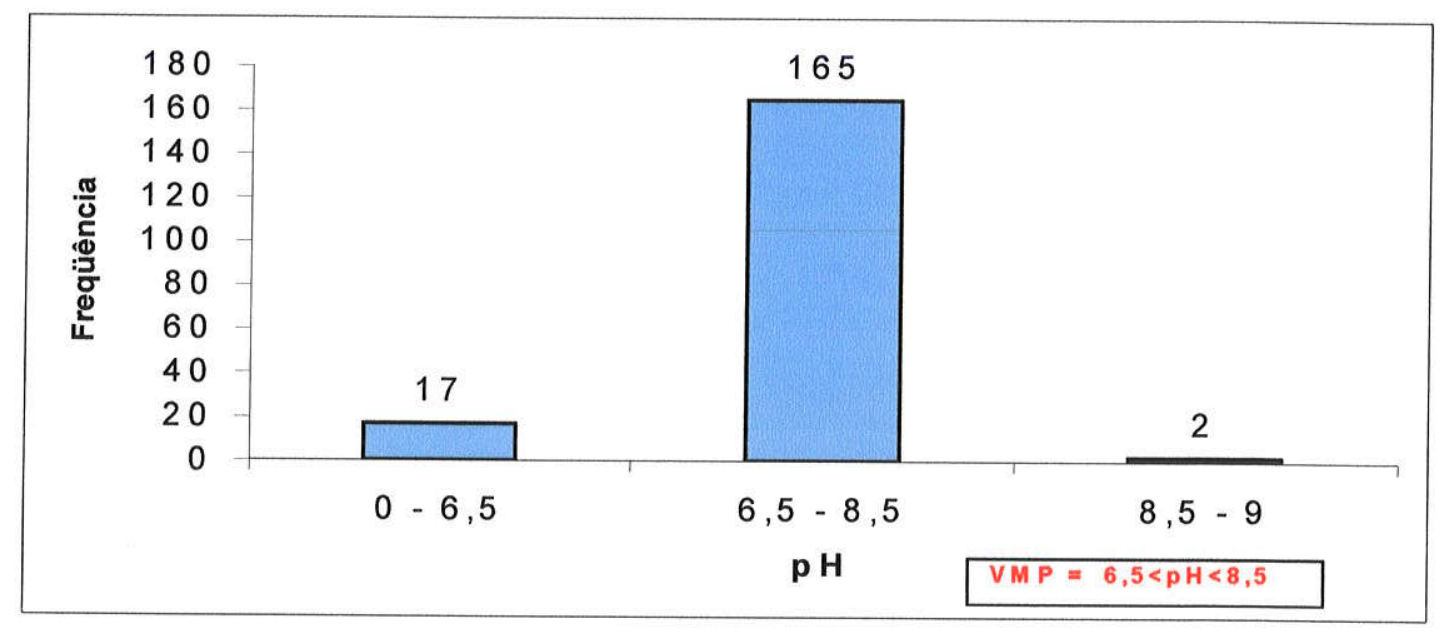

Figura 35. Concentração Hidrogeniônica

Valores estatísticos do $\mathrm{pH}$ :

Média $=7,26$

Máximo $=9$

Mínimo $=2$

Variância $=0,59$

Desvio Padrão $=0,77$

Mediana $=7$

Moda $=7$

\section{Alcalinidade (bicarbonato)}

Das 183 análises realizadas, apenas $17(9,3 \%)$ ficaram acima dos Valores Máximos Permissíveis ao Consumo Humano. 


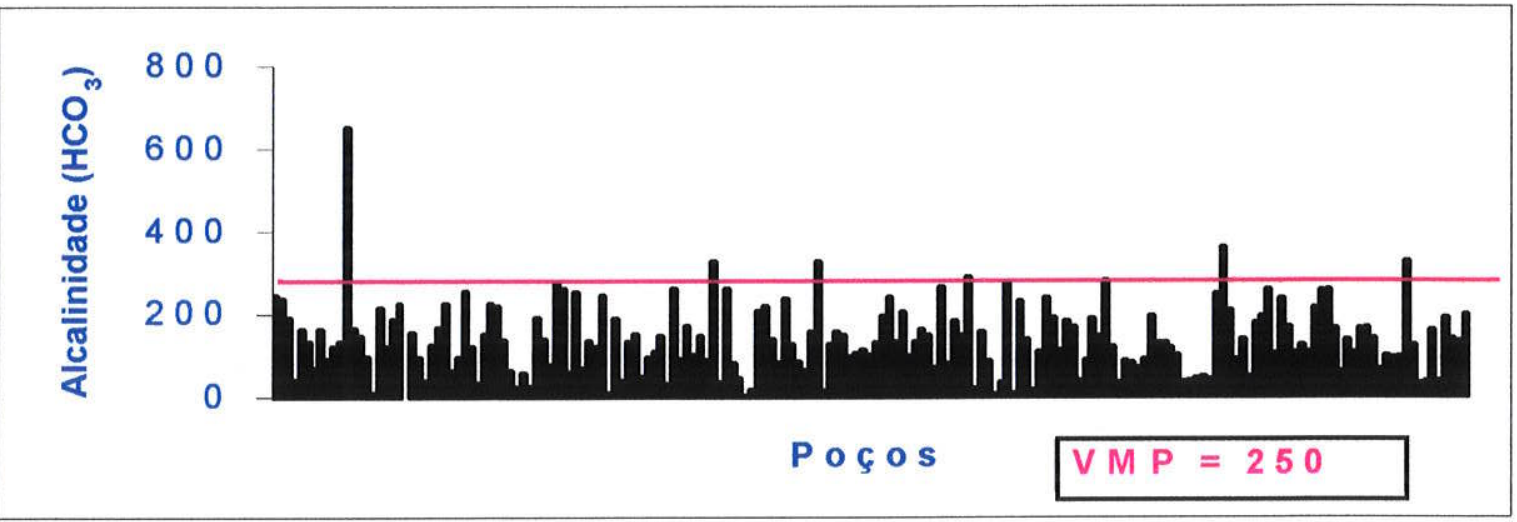

Figura 36. Alcalinidade de Bicarbonato

Valores estatísticos das concentrações (mg/l) de bicarbonato:

Máximo $=650$

Mínimo $=0$

Média $=136$

Mediana $=129$

Moda $=120$

Variância $=7440$

Desvio Padrão $=86$

\section{Alcalinidade (hidróxido)}

Foram realizadas 131 análises, apenas uma análise apresentou concentração acima dos Valores Máximos Permissíveis ao Consumo Humano.

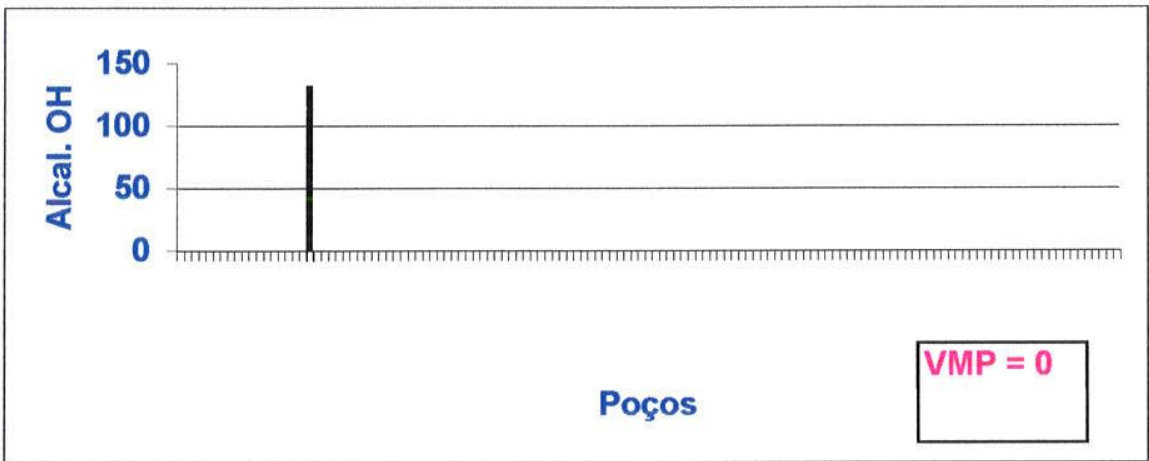

Figura 37. Alcalinidade de Hidróxido 
Valores estatístico das concentrações $(\mathrm{mg} / \mathrm{l})$ de hidróxido:

Média $=1$

Máximo $=131$

Mínimo $=0$

Variância $=131$

Desvio Padrão $=11,4$

Mediana $=0$

Moda $=0$

\section{Alcalinidade (carbonato)}

Das 131 análises realizadas, todas ficaram dentro dos Valores Máximos Permissiveis ao consumo humano.

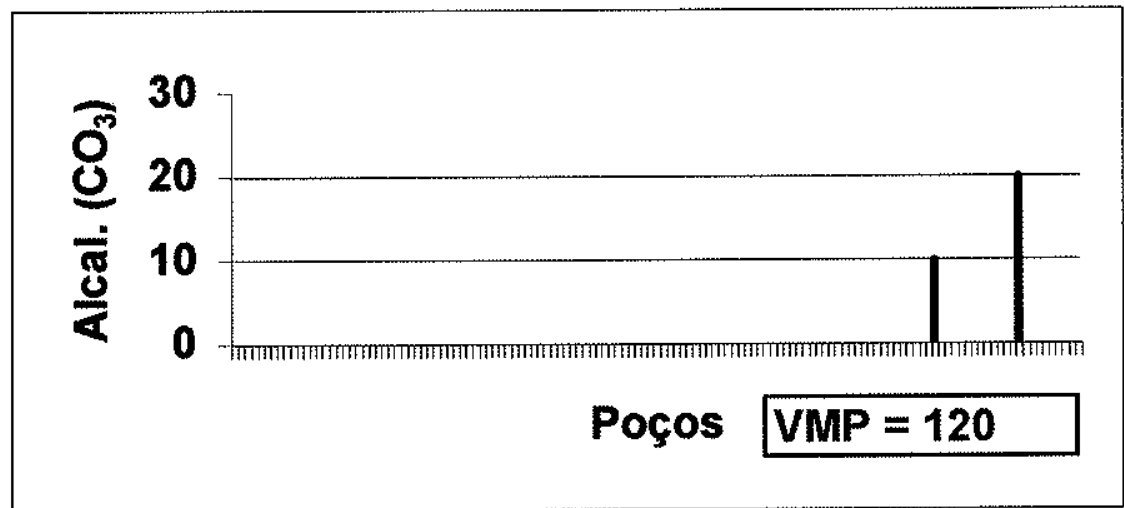

Figura 38. Alcalinidade de Carbonato

Valores estatísticos da concentração $(\mathrm{mg} / \mathrm{l})$ de carbonato:

Média $=0,23$

Máximo $=20$

Mínimo $=0$

Variância $=3,8$

Desvio Padrão $=1,9$

Mediana $=0$

Moda $=0$ 
$\mathrm{CO}_{2}$ livre

Embora não sejam conhecidos efeitos adversos ao homem, foram realizadas 120 análises. As concentrações variaram de 0 a 165 mg/l, com média em 13 mg/l.

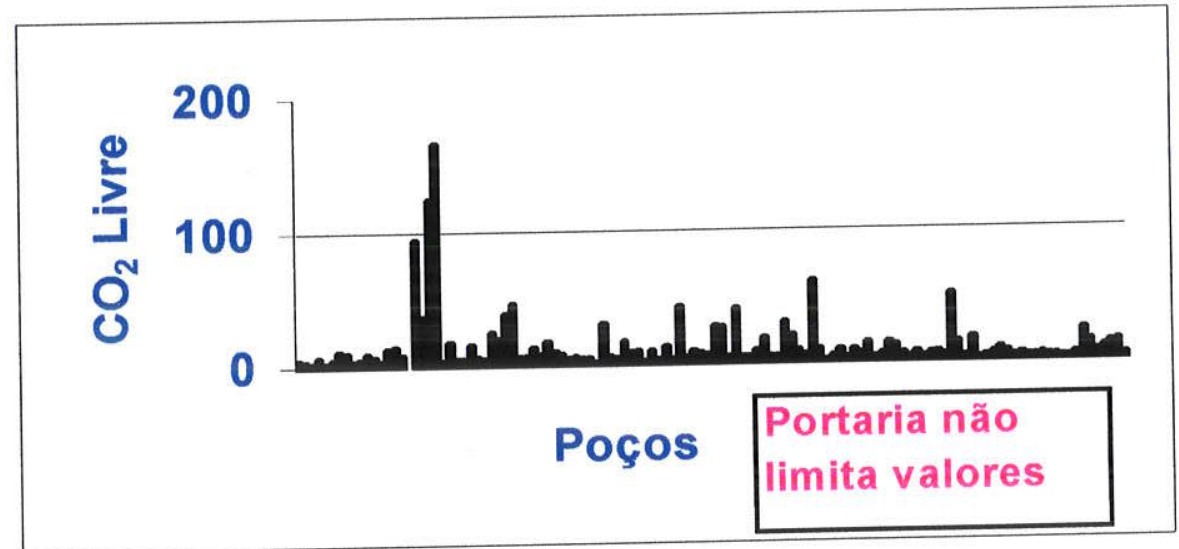

Figura 39. Gás Carbônico.

Valores estatísticos das concentrações $(\mathrm{mg} / \mathrm{l})$ de $\mathrm{CO}_{2}$ livre:

Média $=13$

Máximo $=165$

Mínimo $=0$

Variância $=476,3$

Desvio Padrão $=22$

Mediana $=6$

Moda $=4$ 


\section{Dureza Total}

Foram realizadas 136 análises. Nenhuma amostra apresentou concentração acima dos Valores Máximos Permissíveis ao Consumo Humano. Por outro lado, essas concentrações encontraram-se um pouco altas, a maioria entre 100 e $300 \mathrm{mg} / \mathrm{l}$.

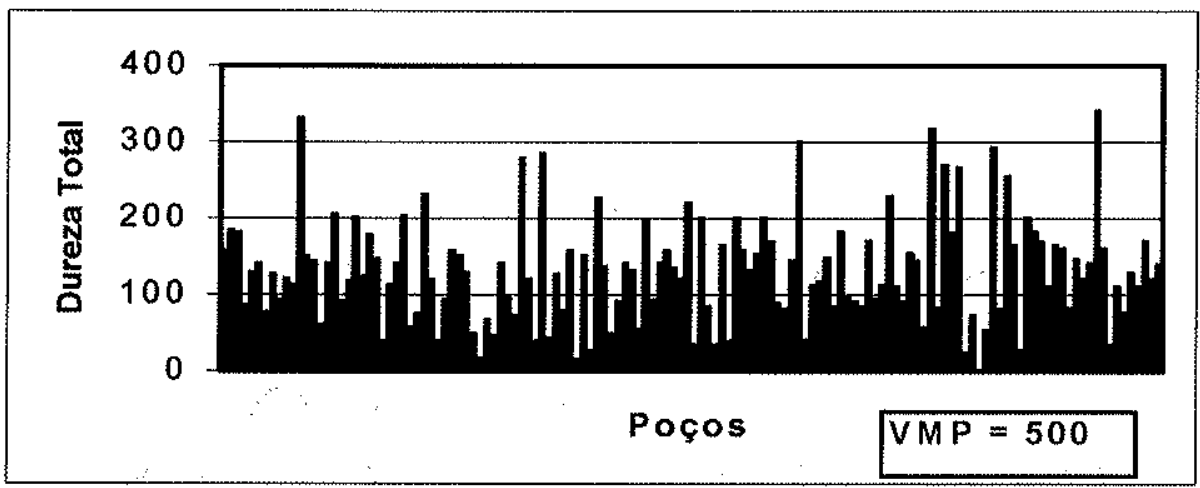

Figura 40. Dureza Total

Valores estatísticos das concentrações $(\mathrm{mg} / \mathrm{l})$ da dureza total:

Média $=130$

Máximo $=340$

Mínimo $=0$

Variância $=\mathbf{4 7 9 0}$

Desvio Padrão $=69$

Mediana $=127$

Moda $=140$

\section{Dureza Permanente}

Foram realizadas 136 análises. A Portaria № 36 de 19 de janeiro de 1990 e o Decreto $N^{\circ} 12.486$ de 20/10/78 não limitam valores à concentração da dureza permanente 


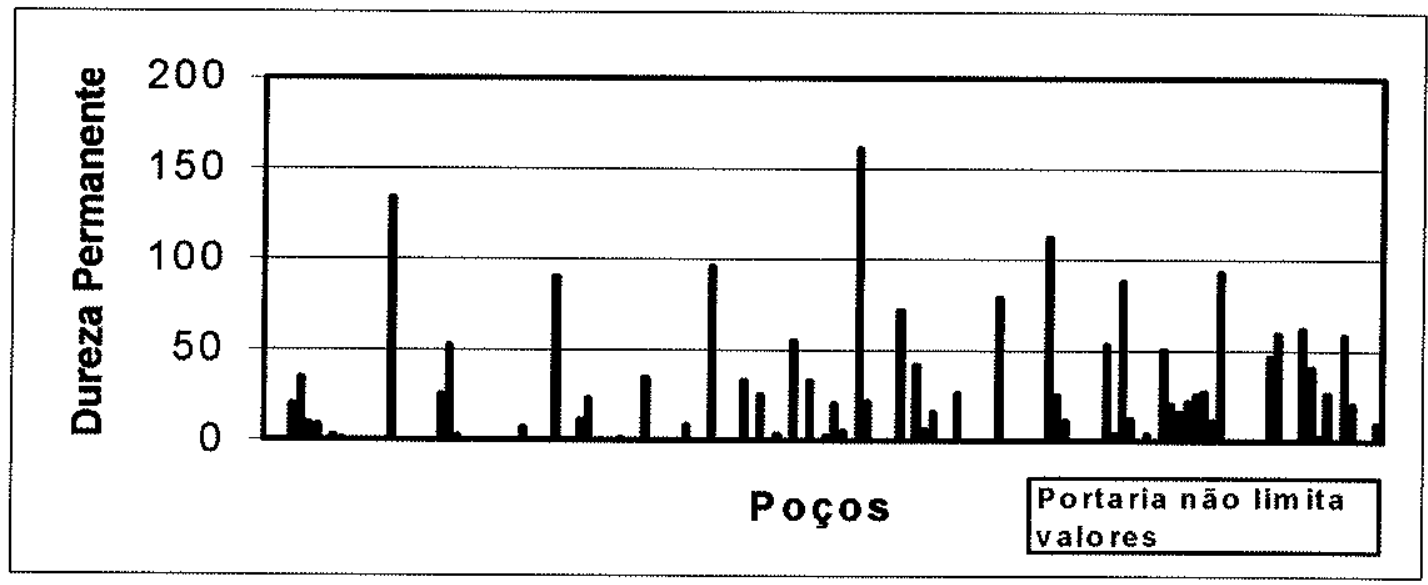

Figura 41. Dureza Permanente.

Valores estatísticos das concentrações $(\mathrm{mg} / \mathrm{l})$ da dureza permanente:

$$
\begin{aligned}
& \text { Média }=15 \\
& \text { Máximo }=161 \\
& \text { Mínimo }=0 \\
& \text { Variância }=825 \\
& \text { Desvio Padrão = } 29 \\
& \text { Mediana }=0 \\
& \text { Moda }=0
\end{aligned}
$$

\section{Dureza Temporária}

Foram realizadas 136 análizes. A Portaria № 36 de 19 de janeiro de 1990 e o Decreto $N^{0} 12.486$ de 20/10/78 não limitam valores à concentração da dureza temporária. 


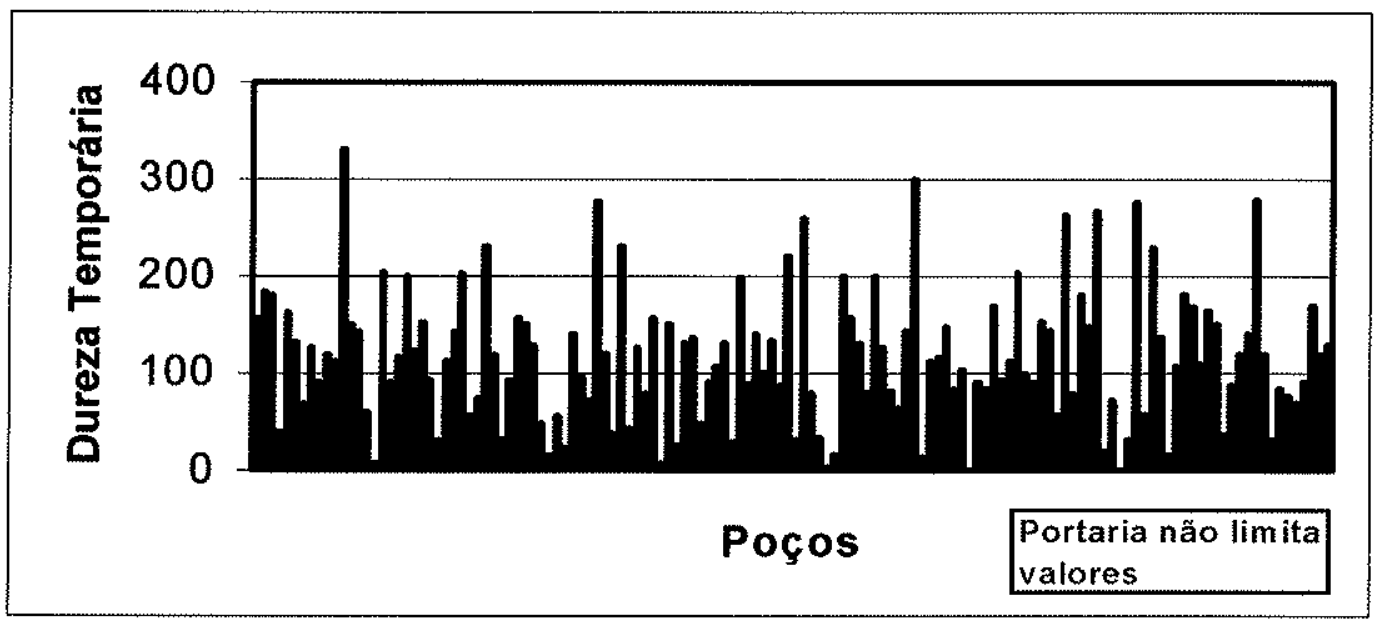

Figura 42. Dureza Temporária.

Valores estatísticos das concentrações $(\mathrm{mg} / \mathrm{l})$ da dureza temporária:

Média $=117$

Máximo $=330$

Mínimo $=0$

Variância $=4.747$

Desvio Padrão $=69$

Mediana $=114$

Moda $=90$

Nitrogênio Amoniacal

Das 114 análises realizadas, somente 5 amostras apresentaram concentração acima dos Valores Máximos Permissiveis ao Consumo Humano. 


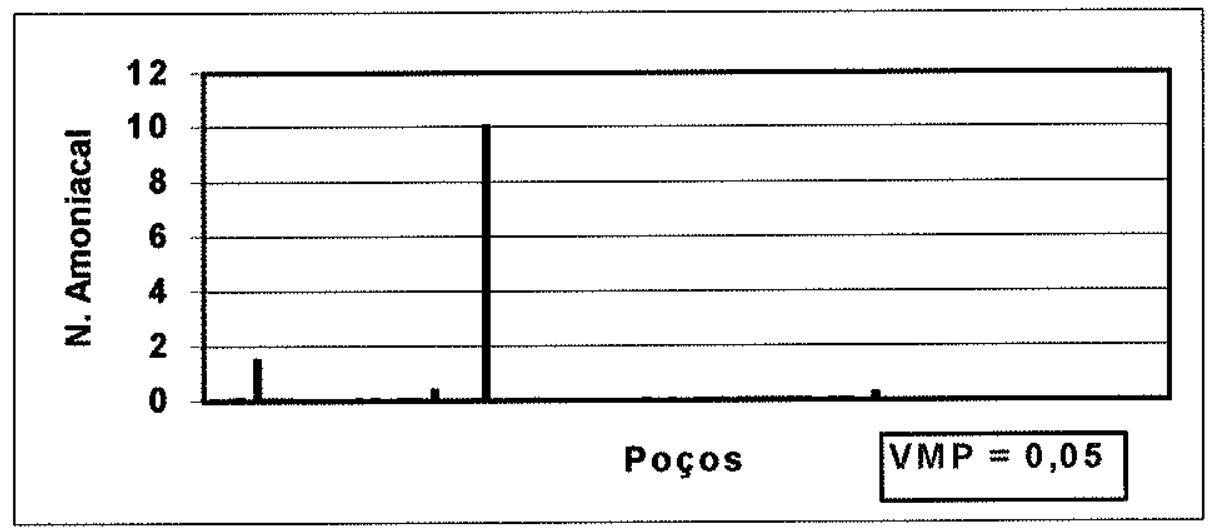

Figura 43. Nitrogênio Amoniacal.

Valores estatísticos das concentrações (mg/l) de nitrogênio amoniacal:

$$
\begin{aligned}
& \text { Média }=0,11 \\
& \text { Máximo }=10 \\
& \text { Mínimo }=0 \\
& \text { Variância }=0,89 \\
& \text { Desvio Padrão }=0,94 \\
& \text { Mediana }=0 \\
& \text { Moda }=0
\end{aligned}
$$

\section{Nitrogênio de Nitrito}

É comum, o nitrogênio de nitrito estar ausente nas águas subterrâneas por ser muito instável. Foram analisadas 152 amostras, somente uma apresentou concentração acima dos valores máximos permissiveis para o consumo humano. $O$ nitrito é um grande indicador de poluição. 


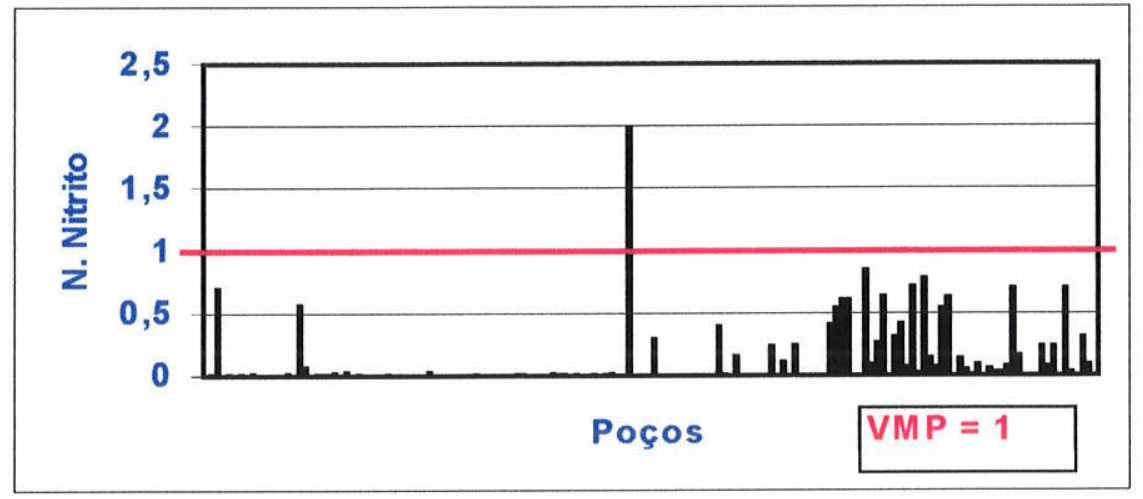

Figura 44. Nitrogênio de Nitrito.

Valores estatísticos das concentrações $(\mathrm{mg} / \mathrm{l})$ de nitrito:

Média $=0,1$

Mínimo $=0$

Máximo $=1,99$

Variância $=0,06$

Desvio Padrão $=0,25$

Mediana $=0$

Moda $=0$

\section{Fosfato}

A portaria $\mathrm{N}^{0} 36$ de 19 de Janeiro de 1990 e o Decreto $\mathrm{N}^{0}$ 12.486, de 20/10/78, não limitam valores ao fosfato. Das 146 análises realizadas, a concentração variou de 0 a $6,7 \mathrm{mg} / \mathrm{l}$, sendo que a grande maioria apresentou concentração inferior a $0,1 \mathrm{mg} / \mathrm{l}$. 


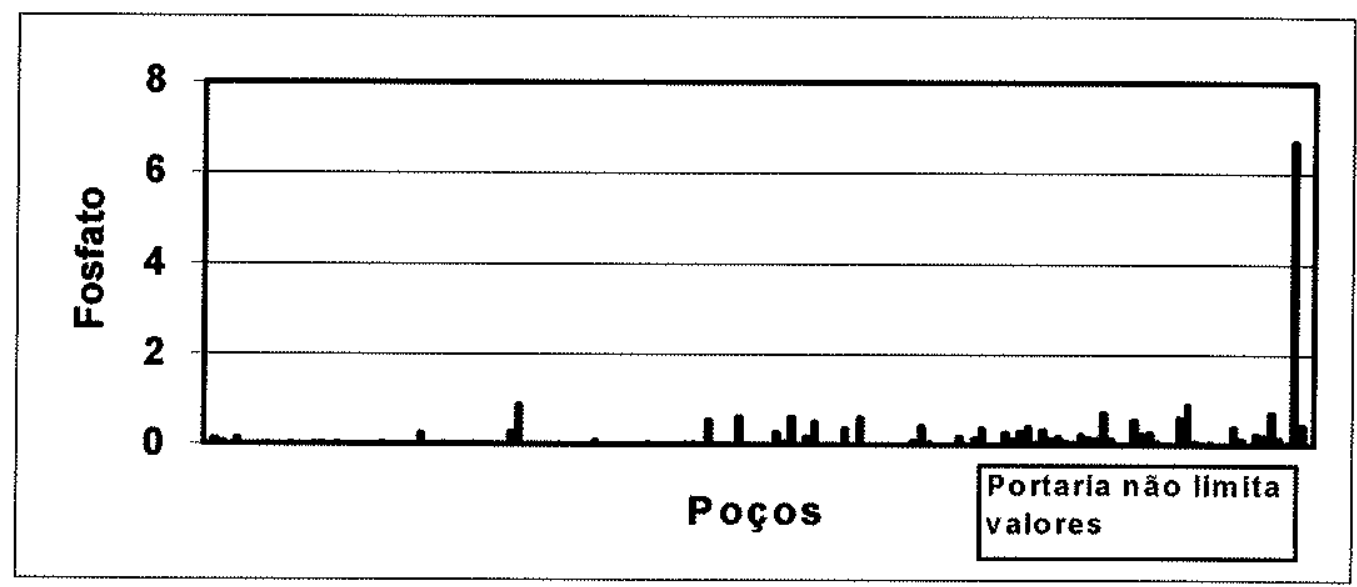

Figura 45. Fosfato.

Valores estatísticos das concentrações $(\mathrm{mg} / \mathrm{l})$ de fosfatos:

$$
\begin{aligned}
& \text { Média }=0,149 \\
& \text { Mínimo }=0 \\
& \text { Máximo }=6,7 \\
& \text { Variância }=0,333 \\
& \text { Desvio Padrão }=0,577 \\
& \text { Mediana }=0,008 \\
& \text { Moda }=0
\end{aligned}
$$

\section{Ferro}

Das 179 análises realizadas, 72 amostras (40\%) apresentaram concentração acima dos Valores Máximos Permissíveis ao Consumo Humano. Duas amostras apresentaram concentração muito elevadas (19 e $38 \mathrm{mg} / \mathrm{l}$ ). 


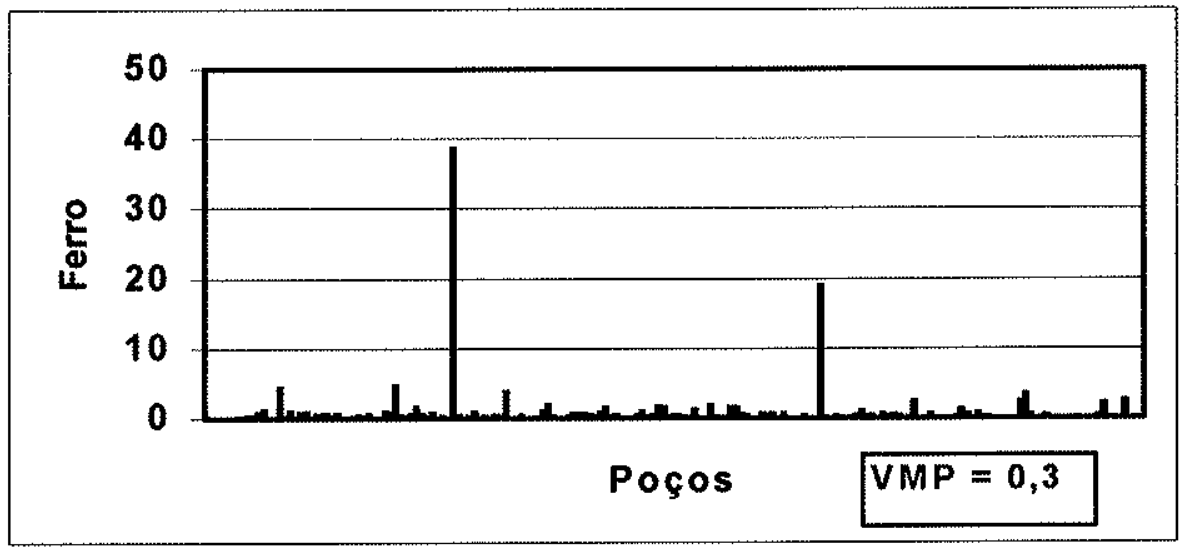

Figura 46. Ferro.

Valores estatísticos das concentrações (mg/l) de Ferro:

Média $=0,78$

Mínimo $=0$

Máximo $=38,7$

Variância $=10,6$

Desvio Padrão $=3,26$

Mediana $=0,21$

Moda $=0$

\section{Cálcio}

Nas 170 análises realizadas a concentração de cálcio variou de 0 a $80 \mathrm{mg} / \mathrm{l}$, sendo que a grande maioria das concentraçôes ficou entre 10 e $40 \mathrm{mg} / \mathrm{l}$. A Portaria $\mathrm{N}^{0}$ 36 de 19 de Janeiro de 1990 e o Decreto $N^{0} 12.486$, de 20/10/78 não limitam valores ao cálcio. 


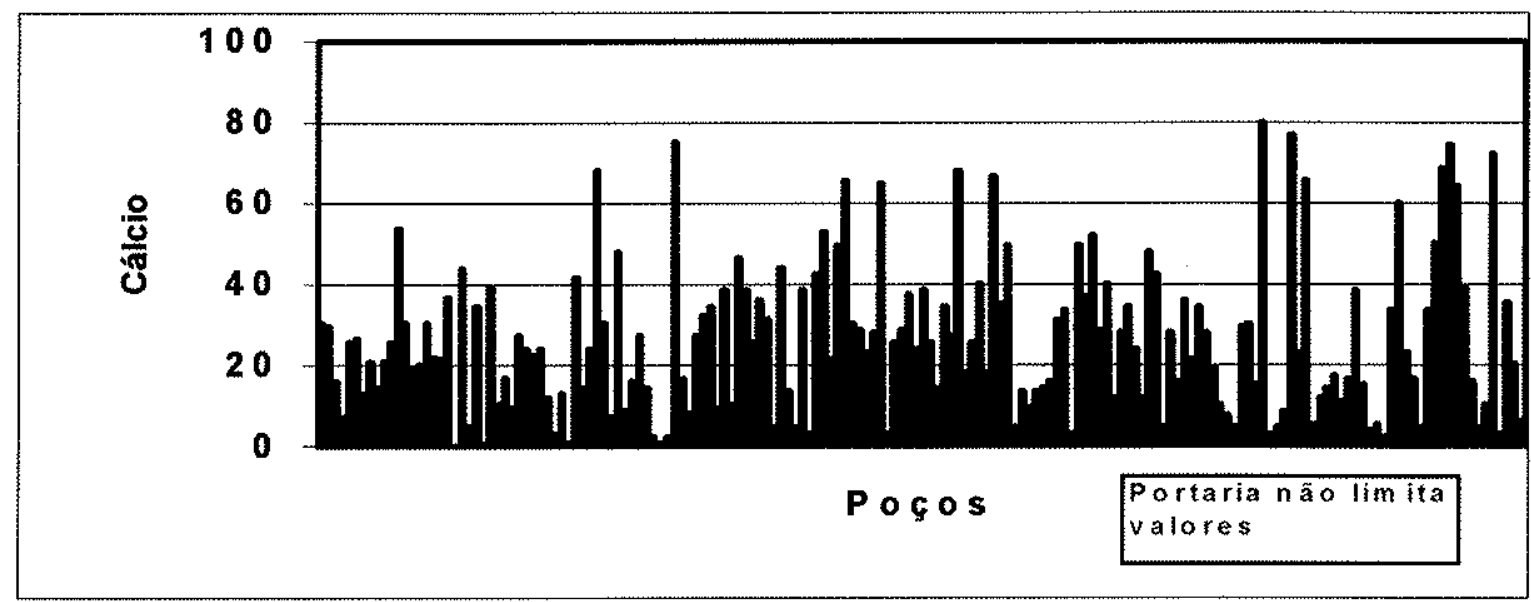

Figura 47. Cálcio.

Valores estatístico das concentrações $(\mathrm{mg} / \mathrm{l})$ de cálcio:

Média $=26,26$

Máximo $=80$

Mínimo $=0$

Variância $=344$

Desvio Padrão $=18,54$

Mediana $=24$

Moda $=4,8$

Cloreto:

Das 171 análises realizadas, nenhuma ultrapassou os Valores Máximos Permissiveis ao Consumo Humano. As concentrações variaram de 1 a $66,84 \mathrm{mg} / \mathrm{l}$. 


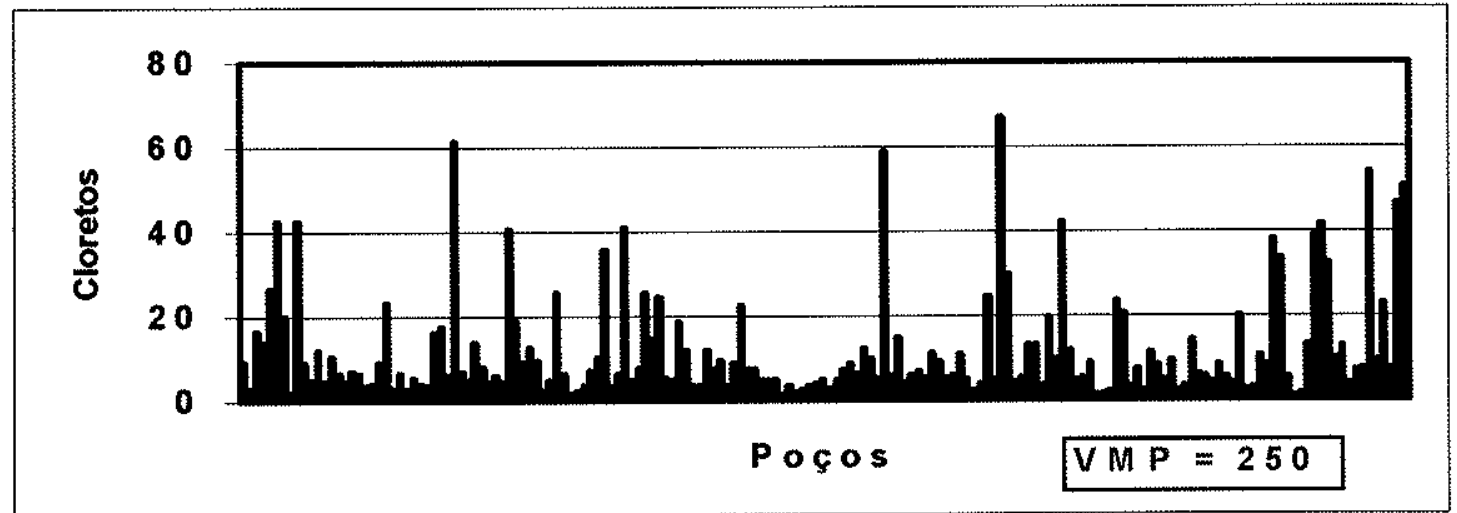

Figura 48. Cloretos

Valores estatísticos das concentrações $(\mathrm{mg} / \mathrm{l})$ de cloretos:

Média $=12$

Mínimo $=1$

Máximo $=66,84$

Variância $=165$

Desvio Padrão $=12,84$

Mediana $=7$

Moda $=5$

\section{Oxigênio Consumido}

Foram realizadas 157 análises, a maioria com baixas concentrações, variou de zero a uma amostra com $28 \mathrm{mg} / \mathrm{l}$, apenas 1 amostra apresentou concentração acima dos Valores Máximos Permissíveis ao Consumo Humano. É bom lembrar que $\circ \mathrm{O}_{2}$ só ocorre em águas subterrâneas de pouca profundidade. 


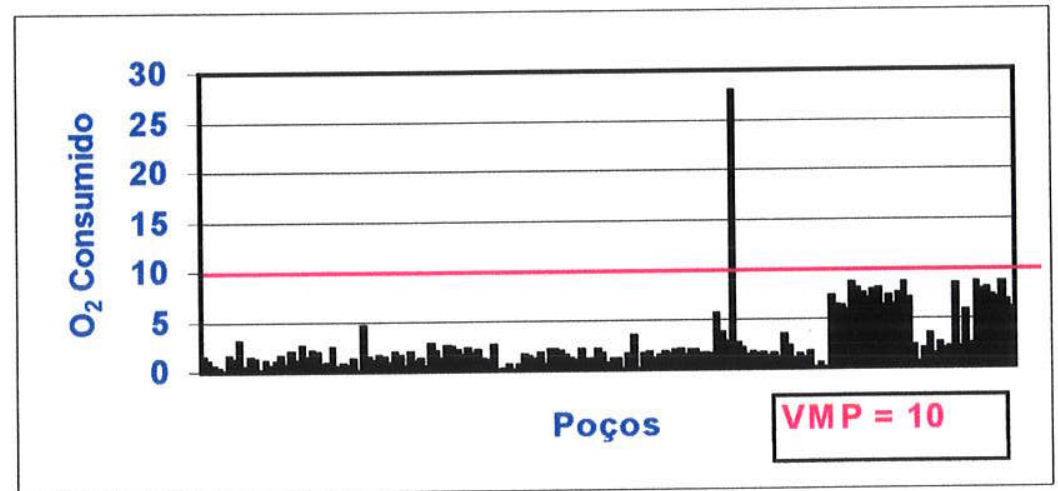

Figura 49. Oxigênio Consumido.

Valores estatísticos das concentrações $(\mathrm{mg} / \mathrm{l})$ de oxigênio consumido:

$$
\begin{aligned}
& \text { Média }=2,5 \\
& \text { Mínimo }=0 \\
& \text { Máximo }=28 \\
& \text { Variância }=9,7 \\
& \text { Desvio Padrão = 3,1 } \\
& \text { Mediana }=1,5 \\
& \text { Moda }=1
\end{aligned}
$$

\section{Coliformes (totais)}

Das 164 análises realizadas, 82 amostras (50\%) apresentaram concentração acima dos Valores Máximos Permissíveis ao Consumo Humano. As concentrações acima do VMP variaram de 2 a 16000 NMP/100 ml de coli-totais. 


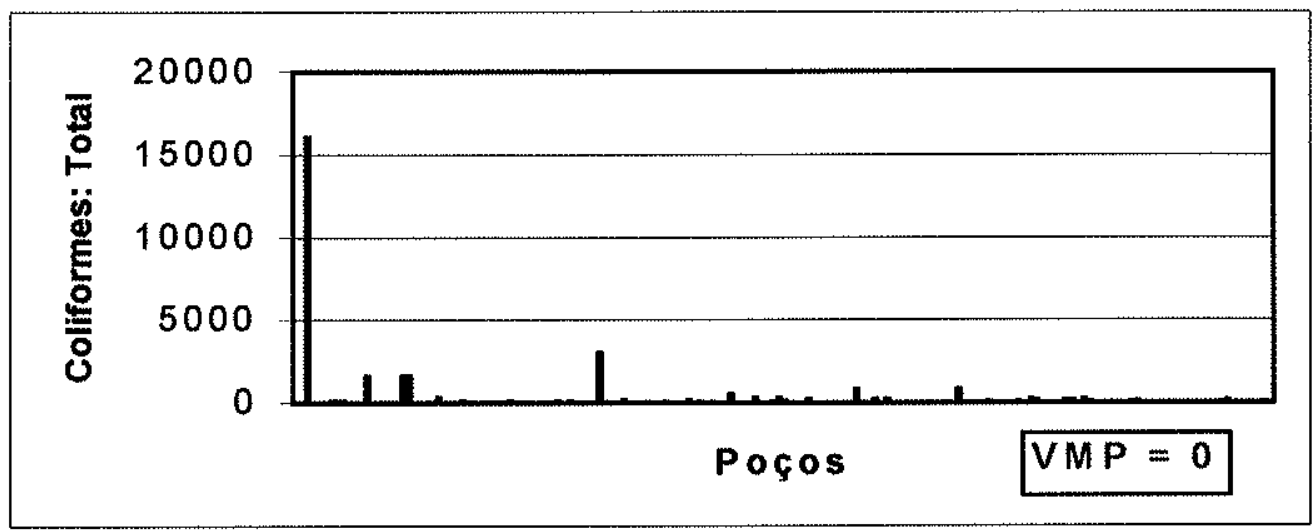

Figura 50. Coliformes Totais.

Valores estatísticos das concentrações (NMP/100ml) de coli-totais:

Média $=187,74$

Mínimo $=0$

Máximo $=16000$

Variância $=1.651 .687$

Desvio Padrão $=1.285,2$

Mediana $=1$

Moda $=0$

\section{Coliformes (fecais)}

Das 144 análises realizadas, 55 amostras (38\%) apresentaram concentração acima dos Valores Máximos Permissíveis ao Consumo Humano. As concentrações acima do VMP variaram de 2 a 5000 NMP/100 ml de coli-fecais, porém a grande maioria $62 \%$ apresentou concentração menor que o VMP. 


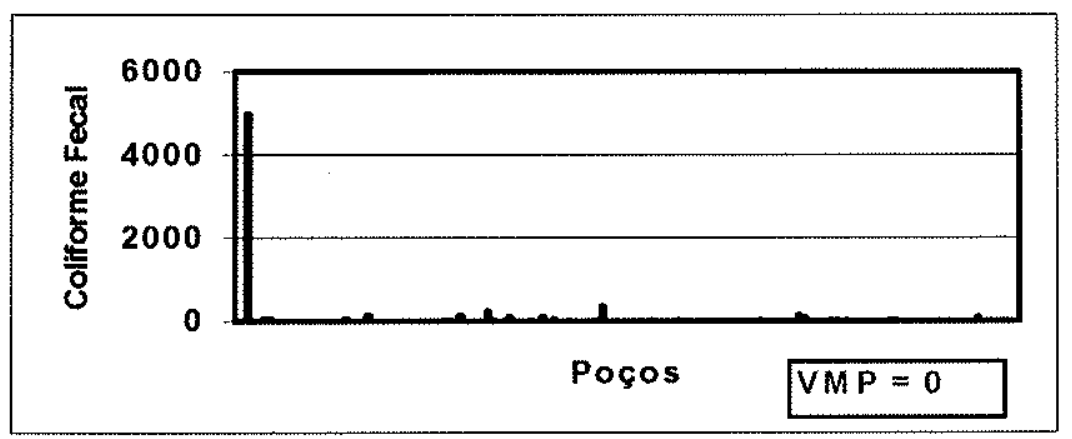

Figura 51. Coliformes Fecais.

Valores estatísticos das concentrações (NMP/100ml) de coli-fecais:

Média $=48,35$

Mínimo $=0$

Máximo $=5.000$

Variância $=174.410$

Desvio Padrão $=417,6$

Mediana $=0$

Moda $=0$

O exame da tabela 14 e das figuras 30 a 48 que mostram os resultados das análises fisico-químicas e bacteriológicas das águas subterrâneas de 188 poços, verifica-se que, 106 poços (56\%) estão fora dos Valores Máximos Permissiveis para o Consumo Humano (VMP) e 82 poços (44\%) mostram-se potáveis de acordo com a Portaria $N^{\circ} 36$, de 19 de Janeiro de 1990 . Os parâmetros que mais se encontraram fora do VMP foram: coliformes (totais e fecais), ferro, cor e turbidez.

Com relação às análises físico-químicas, a turbidez, a cor e o ferro, encontraram-se, em várias amostras, com concentrações superiores aos Valores Máximos Permissíveis ao Consumo Humano. No geral, grande parte das amostras apresentou concentração elevada de $\mathrm{Fe}$, embora abaixo dos Valores Máximos Permitidos ao Consumo Humano. Este fator deve-se ao solo laterítico típico do Grupo Cuiabá e da ocorrência de piritas disseminadas tanto nos filitos como nos 
metadiamictitos Sabemos que o ferro proporciona gosto, turbidez e cor à água e é essencial ao homem em baixas concentrações. Assim, os valores elevados da cor e turbidez podem ser explicados pela alta concentração de ferro nessas águas e pelos poços mal desenvolvidos.

Com relação às análises bacteriológicas, de acordo com a mesma Portaria, 53 amostras não se mostraram potáveis. Isto se deve aos problemas de saneamento básico da região, a inadequadas técnicas construtivas dos poços tubulares profundos e ao meio fissurado

Também devemos ressaltar que, quando as bactérias e vírus são transportados com a água subterrânea no meio poroso, elas são removidas por filtração e adsorção, sendo assim, relativamente imóveis em meio poroso, penetrando pequenas distâncias. Porém, no meio fraturado, que é o caso do Grupo Cuiabá, as distâncias alcançadas podem ser muito grandes. Esse problema é muito preocupante, haja visto a situação do saneamento básico na região, onde encontramos córrregos funcionando como canais de esgoto "in natura" e grande quantidade de fossas sépticas.

Resumindo:

Em geral, as águas subterrâneas do Grupo Cuiabá na região estudada são de boa qualidade, com baixas concentrações dos principais parâmetros físico-químicos estudados, porém os parâmetros bacteriológicos apresentam valores elevados.

Os resultados das análises físico-químicas denotam teores elevados de Ferro $\left(\mathrm{Fe}^{+2}\right)$, cor e turbidez nas águas subterrâneas. As concentrações elevadas de ferro são decorrentes da lixiviação do solo laterítico e das piritas disseminadas tanto nos filitos como nos metadiamictitos. As concentrações elevadas de cor e turbidez podem ser explicadas pela alta concentração de ferro nestas águas aliadas aos poços mal construídos. 
Embora encontram-se poços com concentrações relativamente altas de alcalinidade de bicarbonato, somente $9,3 \%$ estavam acima dos Valores Máximos Permissíveis para o Consumo Humano.

As análises bacteriológicas das águas subterrâneas mostram elevada concentração de coliformes totais e fecais, devido aos problemas de saneamento básico da região (grande quantidade de fossas sépticas, sumidouros e córregos contaminados), aliadas ao meio fraturado e as inadequadas técnicas construtivas dos poços tubulares profundos. 


\section{RETOMADA E DISCUSSÃO DOS PRINCIPAIS RESULTADOS}

Devido a complexidade geológica do terreno e a falta de trabalhos geológicos de detalhe e semi - detalhe que permitissem uma melhor compreensão dos fatores condicionantes que atuam no armazenamento e fluxo das águas subterrâneas, foi elaborado um mapa geológico na escala 1:25.000 (Anexo 02), centrada especialmente na caracterização litológica e no arranjo estrutural dos metassedimentos do Grupo Cuiabá.

$\mathrm{Na}$ área estudada verificou-se que o Grupo Cuiabá expõe-se sob a forma de uma anticlinal invertida com caimento para NE e orientação preferencial do seu traço axial N30-40E (Anexo 02).

Foram descritos dois conjuntos litológicos que correspondem a nossa proposta para o Grupo Cuiabá na área estudada: a Formação Miguel Sutil e a Formação Rio Coxipó.

\section{Formação Miguel Sutil:}

Esta unidade aflora praticamente em toda a porção central e norte das cidades de Cuiabá e Várzea Grande, mais especificamente no núcleo da anticlinal invertida (Anexo 02).

Com base nas estruturas sedimentares e na constituição litológica pudemos individualizar dois conjuntos faciológicos: a Litofácies pelítica (com laminação planoparalela) e a Litofácies argilo-areno-conglomerática.

Nos metassedimentos da Formação Miguel Sutil nota-se uma diferença marcante na instalação de fraturas e veios de quartzo nas Litofácies pelítica com laminação plano paralela e na litofácies argilo-areno-conglomerática. Enquanto o primeiro apresenta uma baixa intensidade de fraturas e veios de quartzo, o segundo mostra-se extremamente diaclasado, com diferentes famílias de juntas e rico em veios 
de quartzo de várias gerações. Este quadro é resultado, principalmente, da diferença de comportamento mecânico das duas litofácies quando submetidos a ação dos esforços. Por um lado, enquanto a litofácies pelítica tende a apresentar um comportamento mais ductil (foliação e dobras), por outro lado, a litofácies argilo-arenoconglomerática comporta-se de forma ruptil, ou seja, sofrem rupturas e deslocamentos das falhas. Como resultado encontramos as melhores condições de armazenamento e circulação de água subterrânea na litofácies argilo-areno-conglomerática.

Um outro parâmetro que influencia a condutividade hidráulica refere-se à textura das rochas. A litofácies pelítica é rica em micas orientadas que definem sua foalição. Estas, por sua vez, dificultam a infiltração de água subterrânea. No entanto, a litofácies argilo-areno-conglomerática, especialmente as mais grosseiros, apresentam uma textura granular, o que resulta em uma maior porosidade e permeabilidade.

Não devemos esquecer também que a alteração da litofácies argilo-arenoconglomerática forma um solo arenoso muito propício à infiltração de águas pluviométricas, formando, desta maneira, excelentes áreas de recarga. Enquanto que, a alteração da litofácies pelítica forma um solo argiloso, laterizado e de pequena profundidade, que retém a infiltração das águas pluviométricas.

Os veios de quartzo desenvolvem-se principalmente nas litologias arenosas e conglomeráticas da Formação Miguel Sutil. São subverticais, perpendiculares as clivagens (S1 e S2) e auxiliam o processo de infiltração das águas subterrâneas nessas litologias.

Por estas razões a Litofácies Pelito-Areno-Conglomerática é a unidade que apresenta as melhores condições de armazenamento e circulação de águas subterrâneas dos metassedimentos da Formação Miguel Sutil. 


\section{Formação Rio Coxipó:}

Esta unidade aflora principalmente na porção sul das cidades de Cuiabá e Várzea Grande, sua exposição restringe-se ao flanco invertido da dobra anticlinal invertida (Anexo 02).

O mapeamento sistemático permitiu a individualizaçào de duas associações litológicas principais: a dos metadiamictitos com matriz argilosa com raras intercalações de areia fina a média e a dos metadiamictitos com matriz arenosa, intercalados a arenitos quartzosos grossos a médios. Pela análise litológica da Formação Rio Coxipó, observa-se que as melhores condições aqüiferas estão localizadas na segunda associação, isto é, nos metadiamictitos de matriz arenosa.

As principais superficies de descontinuidades rochosas e os veios de quartzo do Grupo Cuiabá, na região estudada, relacionam-se às fases de dobramentos que afetaram a região.

Associado a primeira fase de dobramento, foi gerada a superfície de foliação, afetando todas as unidades com direção preferencial $N 40^{\circ}-50^{\circ} \mathrm{E}$ e mergulho para $50^{\circ}-$ $60^{\circ}$, principalmente para NW. Essas superficies embora penetrativas, são fechadas e não facilitam a infiltração de água subterrânea.

Por outro lado às foliações $\mathrm{S} 1$ e S2 (clivagens de crenulação e disjuntivas), a primeira com direção $\mathrm{N} 40^{\circ}-50^{\circ} \mathrm{E}$ e mergulhos variáveis para SE e a outra é ortogonal a S1 e preferencialmente perpendiculares, são originadas por esforços cisalhantes, formando superfícies de descontinuidades ligeiramente abertas, o que facilita a percolação de água subterrânea. Essas superficies de descontinuidades (clivagens) são melhor desenvolvidas nos metadiamictitos e metargilitos, sendo provavelmente responsáveis pelas águas subterrâneas encontradas nestas litologias. É interessante observar que as intersecções dessas clivagens constituem setores mais propicios a infiltração e armazenamento da água subterrânea. 
Os esforços trativos associados ao primeiro evento de dobramento (D1) são responsáveis pela implantação de fraturas trativas, conjugadas ou não, e veios de quartizo perpendiculares ao trend regional. Tal assembléia de fraturas e veios com atitude média N 40-50 W e mergulhos elevados (70-90), são concordantes a S3 e respondem pelo principal fraturamento regional. As diáclases ocorrem mais intensamente nos metadiamictitos da Formação Rio Coxipó e nos metapelitos da Formação Miguel Sutil, enquanto os veios de quartzo são predominantes nos litofácies pelito-areno-conglomeráticos da Formação Miguel Sutil.

O estudo dos relatórios técnicos dos poços perfurados na região de Cuiabá e Várzea Grande mostra que os mesmos são de pequeno porte, com profundidades em torno de 120 metros. São poços revestidos com tubos metálicos ou de plástico nas partes superiores, onde são encontradas rochas alteradas a semi alteradas, e sem revestimento nas partes mais profundas onde as rochas são duras e consolidadas. Nos poços onde o manto de alteração é mais espesso e contém água subterrânea, normalmente são colocados filtros acoplados aos revestimento para aumentar a produtividade dos poços. Poços totalmente revestidos são raros.

A profundidade do nível de saturação (nível estático), em sua grande maioria (88\%), é inferior ou igual a 15 metros, o que indica águas subterrâneas pouco profundas e consequentemente vulneráveis a contaminação.

O nível dinâmico dos poços apresentou grande oscilação, $89 \%$ das medidas entre 20 e 90 metros. Por esta razão, a oscilação do rebaixamento também foi grande, $86 \%$ oscilou entre 10 e 80 metros.

A vazão dos poços comportou-se de forma muito heterogênea, a grande maioria $(70 \%)$, apresentou vazão menor ou igual a $15 \mathrm{~m}^{3} / \mathrm{h}$. Porém, a vazão média foi de 14 $\mathrm{m}^{3} / \mathrm{h}$, para rebaixamento médio de $46 \mathrm{~m}$. Da mesma maneira, a capacidade específica também se comportou de forma heterogênea, onde $65 \%$ são inferiores ou iguais a $0,5 \mathrm{~m}^{3} / \mathrm{h} / \mathrm{m}$. Tal comportamento já era esperado, visto que o aqüifero é fissurado, onde predomina o caráter aleatório do fraturamento e sua conseqüente imprevisibilidade. Devemos ressaltar que esses parâmetros foram calculados a partir de ensaios de 
bombeamento, servindo para fixar uma ordem de grandeza, porém, devemos manter algumas restrições. As observações de rebaixamento e recuperação dos níveis d'água foram feitas no próprio poço, os ensaios de bombeamento foram realizados com ar comprimido, o aqüífero é fissurado, o que muitas vezes, não permite manter uma vazão constante durante todo o ensaio.

Com relação a classificação "produtividade de aqüifero", proposta por Mente \& Mont'Alverne,1.982, torna-se necessário esclarecer que embora seja um indicador interessante, não permite concluir com segurança pois a capacidade específica de poços é um parâmetro temporal. Deve-se levar este fato em conta em qualquer inferência ou conclusão sobre estes resultados. Isto posto, o Grupo Cuiabá, na região de Cuiabá e Várzea Grande, possui produtividade de aqüifero mais freqüente $(54,7 \%)$ classificada como fraca a média, ou seja, as capacidades específicas permanecem no intervalo de 0,1 a $1 \mathrm{~m}^{3} / \mathrm{h} / \mathrm{m}$. Abaixo e acima desta faixa, existem $30 \%$ de poços com produtividade muito fraca, $12,9 \%$ de poços com produtividade média a elevada e $2,4 \%$ de poços com produtividade elevada.

Os parâmetros hidráulicos calculados a partir do modelo de dimensão fractal desenvolvido por Manoel Filho (1996), apresentaram variação muito grande no Grupo Cuiabá. Os testes revelaram que as transmissividades das fraturas variaram de $10^{-}$ ${ }^{7} \mathrm{~m}^{2} / \mathrm{s}$ a $10^{-3} \mathrm{~m}^{2} / \mathrm{s}$ com média de $9,3 \times 10^{-5} \mathrm{~m}^{2} / \mathrm{s}$, as aberturas médias das fraturas variaram de $0,07 \mathrm{~mm}$ a $1,25 \mathrm{~mm}$ com média de $0,337 \mathrm{~mm}$, a condutividade hidráulica das fraturas variou de $0,051 \mathrm{~m} / \mathrm{s}$ a $0,084 \mathrm{~m} / \mathrm{s} \mathrm{com}$ média de $0,144 \mathrm{~m} / \mathrm{s}$, os valores de permeabilidade variaram de $0,008 \mathrm{~m}^{2} / \mathrm{s}$ a $2,6 \mathrm{~m}^{2} / \mathrm{s}$ com média de $0,26 \mathrm{~m}^{2} / \mathrm{s}$ e a porosidade variou de $0,000046 \%$ a $0,00098 \%$ com média de $0,0003 \%$. É interessante observar, que os parâmetros hidráulicos calculados pelo método de dimensão fractal para os para os filitos do Grupo Cuiabá, no geral, apresentaram a mesma ordem de grandeza dos filitos da subprovíncia Escudo Oriental Nordeste, no Estado da Paraiba calculados por Manoel Filho (1996).

A profundidade do manto de alteração é muito variável, desde a completa ausência até profundidades maiores de $100 \mathrm{~m}$. Porém, a grande maioria $(90 \%)$ dos 
poços possui manto de alteração com profundidade menor de $50 \mathrm{~m}$, com média em $20 \mathrm{~m}$.

O exame da tabela 14 e das figuras 30 a 48 que mostram os resultados das análises fisico-químicas e bacteriológicas das águas subterrâneas de 188 poços, verifica-se que, 106 poços (56\%) estão fora dos Valores Máximos Permissíveis para o Consumo Humano (VMP) e 82 poços $(44 \%)$ mostram-se potáveis. Os parâmetros que mais se encontraram fora do VMP foram: coliformes (totais e fecais), ferro, cor e turbidez.

Com relação às análises físico-químicas, a turbidez, a cor e o ferro, encontraram-se, em várias amostras, com concentrações superiores aos Valores Máximos Permissíveis ao Consumo Humano. No geral, grande parte das amostras apresentou concentração elevada de $\mathrm{Fe}$, embora abaixo dos Valores Máximos Permitidos ao Consumo Humano. Este fator deve-se ao solo laterítico típico do Grupo Cuiabá e da ocorrência de piritas disseminadas tanto nos filitos como nos metadiamictitos Sabemos que o ferro proporciona gosto, turbidez e cor à água e é essencial ao homem em baixas concentrações. Assim, os valores elevados da cor e turbidez podem ser explicados pela alta concentração de ferro nessas águas e pelos poços mal desenvolvidos.

Com relação às análises bacteriológicas, 53 amostras não se mostraram potáveis. Isto se deve aos problemas de saneamento básico da região, a inadequadas técnicas construtivas dos poços tubulares profundos e ao meio fissurado

Também devemos ressaltar que, quando as bactérias e vírus são transportados com a água subterrânea no meio poroso, elas são removidas por filtração e adsorção, sendo assim, relativamente imóveis em meio poroso, penetrando pequenas distâncias. Porém, no meio fraturado, que é o caso do Grupo Cuiabá, as distâncias alcançadas podem ser muito grandes. Esse problema é muito preocupante, haja visto a situação do saneamento básico na região, onde encontramos córrregos funcionando como canais de esgoto "in natura" e grande quantidade de fossas sépticas. 
Resumindo:

Em geral, as águas subterrâneas do Grupo Cuiabá na região estudada são de boa qualidade, com baixas concentrações dos principais parâmetros físico-químicos estudados, porém os parâmetros bacteriológicos apresentam valores elevados.

Os resultados das análises físico-químicas denotam teores elevados de Ferro $\left(\mathrm{Fe}^{+2}\right)$, cor e turbidez nas águas subterrâneas. As concentraçőes elevadas de ferro são decorrentes da lixiviação do solo laterítico e das piritas disseminadas tanto nos filitos como nos metadiamictitos. As concentrações elevadas de cor e turbidez podem ser explicadas pela alta concentração de ferro nestas águas aliadas aos poços mal construídos.

Embora encontram-se poços com concentrações relativamente altas de alcalinidade de bicarbonato, somente $9,3 \%$ estavam acima dos Valores Máximos Permissíveis para o Consumo Humano.

As análises bacteriológicas das águas subterrâneas mostram elevada concentração de coliformes totais e fecais, devido aos problemas de saneamento básico da região (grande quantidade de fossas sépticas, sumidouros e córregos contaminados), aliadas ao meio fraturado e as inadequadas técnicas construtivas dos poços tubulares profundos.

Pelo exame da "Carta de Uso e Ocupação do Solo", verifica-se a tendência de ocupação urbana em Cuiabá, para direção nordeste, região do Centro Político Administrativo e na direção sudeste, ao longo da Rodovia Federal BR 364, região do Distrito Industrial de Cuiabá.

Verifica-se, também, que as áreas de solos expostos (áreas garimpadas, cavas de extração de areia e cascalho), são as que apresentam maiores evidências de processos erosivos. 
Observa-se pelo Mapa de Uso e Ocupação do Solo, que a maior parte da cidade de Cuiabá e Várzea Grande, são desprovidas de rede de esgoto e que, alguns bairros, embora possuam rede de esgoto, não possuem estação de tratamento, sendo os efluentes despejados no rio mais próximo.

Verificou-se pelos Mapas Potenciométricos (Figuras 22 e 23) que as águas subterrâneas tendem a fluir das regiões de topografia mais alta para as regiões de topografia mais baixa. Observou-se, também, que a principal área de recarga tem direção N 40-50 E, concordante com o trend regional e que, aparentemente, coincide com a zona de charneira da antiforme invertida (Vide Mapa Geológico anexo 2).

Lembrando que o cálculo utilizado para a recarga profunda da região nos indica apenas uma ordem de grandeza, e que é válido apenas para aqüíferos livres, o estudo feito sugere que o volume de recarga profunda para a região da Baixada Cuiabana é de aproximadamente $1,6 \times 10^{9} \mathrm{~m}^{3} /$ ano. 


\section{MODELO HIDROGEOLÓGICO}

O sistema aqüífero na região de Cuiabá e Várzea Grande é do tipo livre heterogêneo e anisotrópico, com intensa variação lateral e em profundidade. A matriz do corpo rochoso é caracterizada pela inexistência e/ou presença reduzida de espaços intergranulares. A água subterrânea encontra-se, preferencialmente, nas descontinuidades das rochas como fraturas, fissuras, diáclases e outras, isto é, nas porosidades secundárias. $A$ trama $e$ intensidade destas descontinuidades definem 0 potencial do aqüífero. As rochas com este tipo de armazenamento e circulação de águas subterrâneas em hidrogeologia são conhecidas como aqüiferos fissurais.

$\mathrm{Na}$ área estudada, os valores de condutividade hidráulica variam muito de um lugar para outro, assumindo comportamento aleatório. Há variaçőes extremas de litologia e estrutura. Dessa maneira, o caráter aleatório das fraturas, associadas às zonas produtoras de água subterrânea localizadas em pontos preferenciais, proporcionam ao Grupo Cuiabá a ocorrência de zonas aqüíferas.

De uma forma geral, pode-se separar dois domínios hidrogeológicos. Um é o domínio da Formação Miguel Sutil, que ocupa praticamente toda a porção central e norte das cidades de Cuiabá e Várzea Grande. O outro domínio é o da Formação Rio Coxipó, que ocupa principalmente a porção sul da regiáo estudada. No primeiro domínio, a litofácies argilo-areno-conglomerática apresenta as melhores condições aqüiferas $e$, no segundo domínio, os metadiamictitos com matriz arenosa apresentam as melhores condições aqüíferas. (Anexo 02). Convém destacar que outras áreas podem apresentar, também, poços com elevadas vazões, uma vez que este aquífero é muito anisotrópico e heterogêneo e a produtividade dos poços esta muito relacionada às condições locais da permeabilidade do manto de alteração e do tipo e grau de fraturamento.

A produtividade das zonas aqüíferas dependerá das características do manto de alteração e do grau de fraturamento das rochas. As melhores situações são aquelas com um manto de alteração predominantemente arenoso, com grande espessura, 
sobreposto a rochas com elevado grau de fraturamento. Situações intermediárias e em diferentes proporções poderão ser encontradas na área de estudo.

Infelizmente não há informações sobre a profundidade dos fraturamentos das rochas (entradas d'águas principais). As informações sobre a profundidade dos fraturamentos seriam importantes para a definição da profundidade dos poços tubulares perfurados no Grupo Cuiabá.

A principal zona de recarga na região coincide com as áreas de afloramento da litofácies argilo-areno-conglomerática na Formação Miguel Sutil e a segunda com os Metadiamictitos de matriz arenosa, na Formação Rio Coxipó. Neste, as melhores áreas de recarga, encontram-se nos solos Podzólico Vermelho-Amarelo de textura média arenosa, conhecidos na região como areia de goma. As descargas são realizadas através de fraturas e falhas geológicas existentes na região. Por estas estruturas, as águas migram para áreas de topografia mais baixa, dando origem a pequenos córregos e áreas alagadiças, muito comuns na região.

As zonas aqüiferas do Grupo Cuiabá na região estudada, apresentam grau de vulnerabilidade geralmente alta à poluição das águas subterrâneas. $O$ manto de alteração aliado às fraturas das rochas apresentam-se normalmente vulneráveis à infiltração de poluentes, principalmente por coliformes. Nas áreas onde a espessura da zona não saturada é maior, o aqüífero tem maior poder de auto depuração e nas áreas onde o nível d'água é raso, a vulnerabilidade à contaminação aumenta. 


\section{CONCLUSÕES}

As zonas aqüíferas da região de Cuiabá e Várzea Grande são livres, heterogêneas e anisotrópicas.

$\mathrm{Na}$ Formação Miguel Sutil, as melhores condições de armazenamento e circulação de água subterrânea localiza-se na Litofácies argilo-areno-conglomerática. $\mathrm{Na}$ formação Rio Coxipó, as melhores condições aqüiferas localizam-se nos Metadiamictitos de matriz arenosa. Verificou-se pelos Mapas Potenciométricos (Figuras 22 e 23) que as águas subterrâneas tendem a fluir das regióes de topografia mais alta para as regiões de topografia mais baixa. Observou-se, também, que a principal área de recarga tem direção N 40-5- E, concordante com o trend regional e que, aparentemente, coincide com a zona de charneira da antiforme invertida.

A situação sanitária da região estudada é precária, apresentando muitas falhas que podem provocar a contaminação das águas subterrâneas e superficiais.

As águas subterrâneas do Grupo Cuiabá na região estudada são normalmente de boa qualidade, com baixas concentrações dos principais parâmetros físico-químicos estudados, porém os parâmetros bacteriológicos apresentam concentrações elevadas. Os resultados das análises físico-químicas mostraram teores acima dos Valores Máximos Permissíveis para o Consumo Humano de Ferro $\left(\mathrm{Fe}^{+3}\right)$, cor e turbidez nas águas subterrâneas. As concentrações elevadas de ferro são decorrentes da lixiviação do solo laterítico e da ocorrência de piritas disseminadas tanto nos filitos como nos metadiamictitos. As concentrações elevadas de cor e turbidez podem ser explicadas pela alta concentração de ferro nestas águas, aliados aos poços mal construídos. As análises bacteriológicas das águas subterrâneas mostram elevada concentração de coliformes totais e fecais, devido aos problemas de saneamento básico da região (grande quantidade de fossas sépticas, sumidouros e córregos contaminados), aliados ao meio fraturado e às inadequadas técnicas construtivas dos poços tubulares profundos. Embora encontra-se poços com concentrações relativamente altas de 
alcalinidade de bicarbonato, somente $9,3 \%$ estavam acima dos Valores Máximos Permissíveis para o Consumo Humano.

Lembrando que o cálculo utilizado para a recarga profunda da região nos indica apenas uma ordem de grandeza, e que é válido apenas para aqüíferos livres, o estudo feito sugere que o volume de recarga profunda para a região da Baixada Cuiabana é de aproximadamente $1,6 \times 10^{9} \mathrm{~m}^{3} /$ ano. 


\section{SUGESTÕES}

As regiões metropolitanas de Cuiabá e Várzea Grande sofreram um acelerado e desordenado crescimento da população urbana e da industrialização. Esse crescimento acelerado e desordenado ocasionou a poluição e contaminação das águas subterrâneas e superficiais pela descarga de resíduos municipais e industriais.

O objetivo deste capitulo é propor sugestões aos problemas detectados ao longo deste trabalho, a fim de satisfazer as necessidades de água subterrânea para as atividades humanas nas regiões metropolitanas de Cuiabá e Várzea Grande, dando-se prioridade à satisfação das necessidades básicas e à proteção dos recursos hídricos subterrâneos. As sugestões são as seguintes:

1) Apoiar a Fundação Estadual do Meio Ambiente (FEMA) no tocante ao cumprimento da Lei $N^{\circ} 7.083$, de 23 de dezembro de 1998 (que já foi aprovada na Assembléia Legislativa do Estado de Mato Grosso), que tem por objetivo, fundamentalmente, regulamentar a perfuração de poços tubulares no Estado de Mato Grosso. A partir da existência dessa Lei a FEMA terá o poder de delegar sobre os recursos hídricos subterrâneos no Estado e poderá desenvolver um banco de dados com informações dos poços tubulares. Poderá desenvolver, também, modelos de previsão, incluindo métodos de avaliação de impacto ambiental e montar estratégias de proteção. A FEMA terá, ainda, condições legais para implementar mecanismos de cobrança sobre o consumo de água subterrânea adotando medidas regulamentadoras, enfim, poderá integrar o planejamento e manejo sobre a qualidade e quantidade dos recursos hídricos subterrâneos no Estado de Mato Grosso.

2) Montar estratégias para divulgação e conscientização da população para o uso racional da água por meio de programas educacionais, tais como organizaçóes de seminários, cursos, palestras, propagação através da mídia, sobretudo, televisão, e cartilhas didáticas distribuídas nas escolas com a finalidade de minimizar o desperdício de água, pretendendo educar e conscientizar o público sobre a proteção dos recursos hídricos de superfície e subsuperfície. 
3) Promover a cooperação financeira através de convênios visando o estudo contínuo de pesquisas científicas sobre os recursos hídricos subterrâneos na região.

4) Desenvolver fontes alternativas de abastecimento a exemplo de reposição artificial de águas subterrâneas e o aproveitamento de águas residuais.

5) São inúmeros os impactos ambientais causados por problemas graves que afetam a qualidade da água superficial e subterrânea: falta de esgoto, lançamento de esgoto nos rios, fossas sépticas, sumidouros, falta de tratamento suficiente de esgoto, estações de tratamento de esgoto não operados em toda sua capacidade por falta de ligações, controle inadequados de efluentes industriais, ocupação através de invasões ocasionando a formação de favelas em locais sem nenhuma infra-estrutura levando alguns córregos a funcionar como canais de esgoto, além de lixo e entulho jogados em seu leito, disposição do lixo de forma inadequada, desmatamento, degradação do solo ocasionada pelos garimpos. Para sanar ou reduzir esses impactos, isto é, para melhor proteger os recursos hídricos subterrâneos e superficiais, sugerimos as seguintes atividades:

- Organizar programas de prevenção visando a proteção, controle da poluição e conservação dos recursos hídricos superficiais e subterrâneos;

- Avaliar o impacto ambiental e estabelecer normas obrigatórias para descargas de fontes poluidoras;

- Desenvolver programas de gerenciamento e monitoramento da qualidade da água;

- Adotar medidas administrativas e legislativas para a ocupação ordenada nas regiões onde se encontram as zonas aqüiferas;

- Construir estações de tratamento de esgoto doméstico e efluentes industriais;

- Prevenir e minimizar a poluição das águas subterrâneas e superficiais por mudança de processos, reutilização, reciclagem, recuperação, tratamento e eliminação segura dos efluentes;

- Promover a reciclagem e reutilização das águas residuais e dos resíduos sólidos;

- Estimular a participação da população na coleta, reciclagem e eliminação dos resíduos domésticos; 
- Controle intensificado na instalação de focos potenciais de poluição como: industrias, aterro sanitários, postos de gasolina, cemitérios e outros;

- Fiscalizar a descarga de resíduos industriais e hospitalares;

- Elaborar projetos visando a construção adequada de aterros sanitários, cemitérios e indústrias potencialmente poluidoras, com base em informações hidrogeológicas e avaliação de impacto ambiental;

- Monitoramento, quando necessário, da qualidade das águas subterrâneas e superficiais potencialmente afetadas por locais de armazenagem de materiais perigosos, tais como poços de gasolina, indústrias que enterram rejeitos perigosos, cemitérios, dentre outros;

- Proteger e monitorar as áreas de recarga, além de evitar sua intensa ocupação;

- Esclarecer e incentivar os proprietários de poços a realizarem análises bacteriológicas das águas periodicamente.

6) Os poços tubulares na região de Cuiabá e Várzea Grande são do tipo parcialmente revestido, com profundidade de revestimento em torno de 30 a 40 metros e espessura variável. A profundidade média dos poços é de 120 metros. Mostraremos a seguir, os principais erros construtivos e posteriormente, as soluções para a problemática da qualidade construtiva dos poços.

\section{Erros Construtivos Principais:}

- Uso de água não tratada durante a perfuração, isto é, usar água de lagoas ou rios contaminados durante a perfuração;

- Não execução da desinfecção dos equipamentos antes do início da perfuração;

- Não isolar as camadas indesejáveis durante a perfuração, isto é, não cimentar as zonas de alterações das rochas ou impermeabilizar alguma camada rica em matéria orgânica;

- Não observar, quando for locar o poço, a existência de possíveis focos de poluição, a exemplo de fossas sépticas, depósitos de lixo, rios ou lagos contaminados, postos de gasolina, depósitos de efluentes industriais, poços abertos e abandonados, além de outros focos de contaminação; 
- Não desenvolver satisfatoriamente e nem desinfectar os poços depois de construídos;

- Locação inadequada de filtros e tubos lisos. É comum encontrar poços com filtro localizado em pequena profundidade impossibilitando uma boa filtração das águas subterrâneas pela formação geológica assim como poços com problemas de infiltração de água superficial contaminada pelo espaço anelar entre o tubo de revestimento e o buraco cavado, além de poços com espessura de revestimento insuficientes e até desprovidos destes;

- Não observar, durante a cimentação, que o espaço anelar entre o tubo de revestimento e a formação geológica é muito estreito, o que pode provocar a presença de bolhas de ar. Também é comum, não observar se a calda de cimento e areia alcança a profundidade desejada;

- Poços abandonados e abertos que provocam contaminação direta do aqüífero;

- Poços construídos inadequadamente provocam presença de sólidos (areias, siltes e argilas), os quais podem penetrar pelo revestimento ou pelo filtro.

\section{Solucões para os Erros Construtivos Principais:}

- Usar água de qualidade durante a perfuração e após o desenvolvimento e executar uma super cloração;

- Construir uma proteção sanitária (cimentação) com, no mínimo, 15 metros de profundidade;

- O espaço anelar entre o tubo de revestimento e a formação geológica deve ter, no mínimo, diâmetro de 4", para evitar bolhas de ar e a não descida da calda de cimento e areia até a profundidade desejada;

- Observar, quando da locação, se existe pontos de contaminação ou poços preexistentes;

- Isolar e lacrar os poços desativados;

- Usar eletrólise para combater o ferro ou implemetar tratamento à base de cloro;

- Desenvolvimento adequado com compressor, química (adição de ácido cítrico, hexametafosfato, dispergel ou outros produtos) e posterior desinfecção; 
- Usar tubos de PVC, sempre que possivel, quando for escolher o revestimento para evitar incrustação de ferro. 


\section{BIBLIOGRAFIA}

ALMEIDA, F. F. M. de. (1964) Geologia do Centro-Oeste Mato-grossense. In: Boletim da Divisão de Geologia e Mineralogia. Rio de Janeiro (215): 1-133.

ALMEIDA, F. F. M. de. (1965) Geossinclinio Paraguaio. In: Anais da 1a. Semana de Debates Geológicos. Porto Alegre, Universidade Federal, Centro Acadêmico dos Estudantes de Geologia, 141p., 87 - 101

ALMEIDA, F. F. M. de. (1984) A Provincia Tocantins - Setor Sudeste. In: ALMEIDA, F. F. M. de. Y. Coords. O Pré-Cambriano do Brasil. São Paulo, Edgard Blücher, p.265 - 281.

ALMEIDA, F. F. M. de. (1985) Alguns Problemas das relações geológicas entre o cráton amazônico e as faixas de dobramentos marginais a leste. Anais do $2^{\circ}$. Simpósio de Geologia do Centro-Oeste. Goiânia, Ata. NCO / SBG, 1985, p. 03 14.

ALVARENGA, C. J. S. de. (1985) Evidências de fáceisturbidíticas grosseiras no Grupo Cuiabá - MT. Anais do $2^{\circ}$. Simpósio de Geologia do Centro-Oeste. Goiânia, Ata. NCO/SBG, 1985, p. $256-266$.

ALVARENGA, C. J. S. de. CATHELINEAU, M. \& DUBESSY, J. (1990) Chronology and orientation of $\mathrm{N} 2-\mathrm{CH}_{4} \mathrm{CO} 2-\mathrm{H} 2 \mathrm{O}$, and $\mathrm{H} 2 \mathrm{O}$ - Rich fluid-inclusion trails in intrametamorphic quartz veins from the Cuiabá gold district, Brazil. Mineralogical Magazine. vol. 54, p. 245 -255, June, .

ALVARENGA, C. J. S. de. \& TROMPETTE, R. (1993) Evolução Tectônica Brasiliana da Faixa Paraguai: a estruturação da Região de Cuiabá. Revista Brasileira de Geociências. v. 23, p. 18-30. 
BARROS, A. M.; SILVA, R. M.; CARDOSO, O. R. F.A.; FREIRE, F. A.; SOUZA, J. J. Jr.; RIVETTI, M.; LUZ, D. S.; PALMEIRA, R. C. B.; TASSINARI, C. C. G. (1982) Geologia, In: Radambrasil, Folha SD-21 Cuiabá, Rio de Janeiro, MME - SG, (Levantamento de Recursos Naturais), Vol. 26, p. 25 - 192.

BOLETIM AGROCLIMATOLÓGICO. (1996). Instituto Nacional de Meteorologia INMET. Brasilia, $n^{\circ 5}$. 01-12, vol. 30.

BOLETIM AGROCLIMATOLÓgICO. (1997). Instituto Nacional de Meteorologia INMET. Brasília, $\mathrm{n}^{\text {os. }}$ 01-12, vol. 31.

CAMPELO JR., J.H.; CASEIRO F. T. (1989) Métodos de Estimativa da Evapotranspiração Potencial. Relatório de Pesquisa. UFMT/SAGRI/PRONI. Cuiabá-MT, 1-31 p.

CETESB (1993). Legislação: Água para Consumo Humano - Potabilidade - Fluoretação Série Documentos, São Paulo, p. 53-63.

CORREA FILHO, V.(1925) Subsídios para o Histórico da Mineração em Mato Grosso. Revista do Instituto Histórico de Mato Grosso, Ano 7, n 14, p 25.

EVANS, J. W. (1894) The Geology of Mato Grosso (Particularly the region drained by the upper Paraguay); Quart. Journal Soc. London, Londres, 50 (2): 85 - 104, .

FEMA - PNMA (1996) - Proposta de Enquadramento dos Principais Corpos D'Água da Bacia do Rio Cuiabá.

FEMA - EMPAER (1996) - Projeto de Recuperação e Conservação do Rio Cuiabá, Anexo III, Cuiabá.

GALVÃO, M. V. org. (1960). Geografia do Brasil, grande região centro-oeste. Rio de Janeiro, Conselho Nacional de Geografia, 452p. 
HASUI, Y; TASSINARI, C. C. G.; SIGA, Jr. O.; TEIXEIRA, W.; ALMEIDA, F. F. M.; KAWASHITA, K. (1981). Idade Rb/Sr e K/Ar do Centro Norte do Brasil e seu significado geológico e tectônico. Anais do XXXI Congresso Brasileiro de Geologia. 5: 2659 - 2676. Camboriu - SC.

INSTITUTO BRASILEIRO DE GEOGRAFIA E ESTATÍsTICA / IBGE (1996). Contagem da População, Vol.1, Cuiabá.

LUZ, J. da S.; OLIVEIRA, A. M.; SOUZA, J. O.; MOTTA, J. F. M.; TANNO, L. C.; CARMO, L. S. do \& SOUZA, N. B. (1980). Projeto Coxipó. Goiânia, DNPM/CPRM, v. 1.136 p. (Relatório Final).

MAITELLI, G. T. (1994). Uma Abordagem Tridimensional de Clima Urbano em Área Tropical Continental: $O$ Exemplo de Cuiabá-MT. São Paulo, 204 p. (Tese de Doutorado / Faculdade de Filosofia, Letras e Ciências Humanas da Universidade de São Paulo).

MANOEL FILHO, J. (1996). Desenvolvimento e Aplicação de Modelo de Dimensão Fractal para Análise de Testes de Produção de Poços em Meio Fissural. São Paulo, 197 p. ( Tese de Doutorado / Instituto de Geociências da Universidade de São Paulo).

MENTE, A. \& MONT'ALVERNE, A.F. (1982). Mapa Hidrogeológico do Brasil na Escala de 1:5.000.000. Anais do: Congresso Brasileiro de Águas Subterrâneas, 2. Salvador, ABAS, p. 111-117.

SANEMAT (1987 a 1996). Relatórios de Dados Operacionais.

SCHOBBENHAUS, C.; CAMPOS, D. A.; DERZE; G. R. \& ASMUS, H. E. (1.984). Geologia do Brasil. Texto Explicativo do Mapa Geológico do Brasil e da Area Oceânica Adjacente incluindo Depósitos Minerais. DNPM, Brasília. 501 p. 
SILVA, L. J. H. D. (1990). Ouro no Grupo Cuiabá, Mato Grosso: controles estruturais e implicações tectônicas. Anais do XXXVI Congresso Brasileiro de Geologia. Natal, Anais SBG, v. 6, p. 2520-2534.

SoUZA, N. B. (1981). O Grupo Cuiabá na área do Projeto Coxipó. Estratigrafia e Potencialidade Econômica. Anais do I Simpósio de Geologia do Centro-Oeste. Goiânia, Atas SBG, p. 226-239.

STANDARD METHODS FOR THE EXAMINATION OF WATER AND WASTEWATER. (1985). APHA, AWWA, WPCF, 16 th ed., Port City Press, Baltimore, 770p.

TEIXEIRA, Telma P.de Barros. (1997). Avaliação do Setor de Saneamento no Estado de Mato Grosso: Estudo de Caso Subbacia do Rio Cuiabá. Cuiabá, 123p.(Monografia de Especialização em Qualidade Ambiental e Recursos HídricosDept $^{\circ}$. Eng ${ }^{a}$. Sanitária e Ambiental/UFMT).

TUBELIS, A.; NASCIMENTO, F. J. L. (1983). Metodologia Descritiva: fundamentos e aplicações brasileiras. Editora Nobel, 374p., São Paulo-SP.

UFMT (1990). Carta Geotécnica de Cuiabá. Relatório final do convênio UFMT/Prefeitura Municipal de Cuiabá, módulo I, 66 a 69 p., Cuiabá-MT.

VECCHIATO, A.B. (1987). Fotointerpretação Geológico-Geotécnica Aplicada ao Planejamento Urbano de Cuiabá e Várzea Grande - MT. Piracicaba, 144p. (Dissertação de mestrado apresentada à Escola Superior de Agricultura Luiz de Queiroz, da Universidade de São Paulo).

VECCHIATO, A. B. (1993). Mapeamento Geotécnico da Área Urbana de Cuiabá-MT. São Carlos, 200p. (Tese de Doutorado apresentada à Escola de Engenharia de São Carlos da Universidade de São Paulo). 

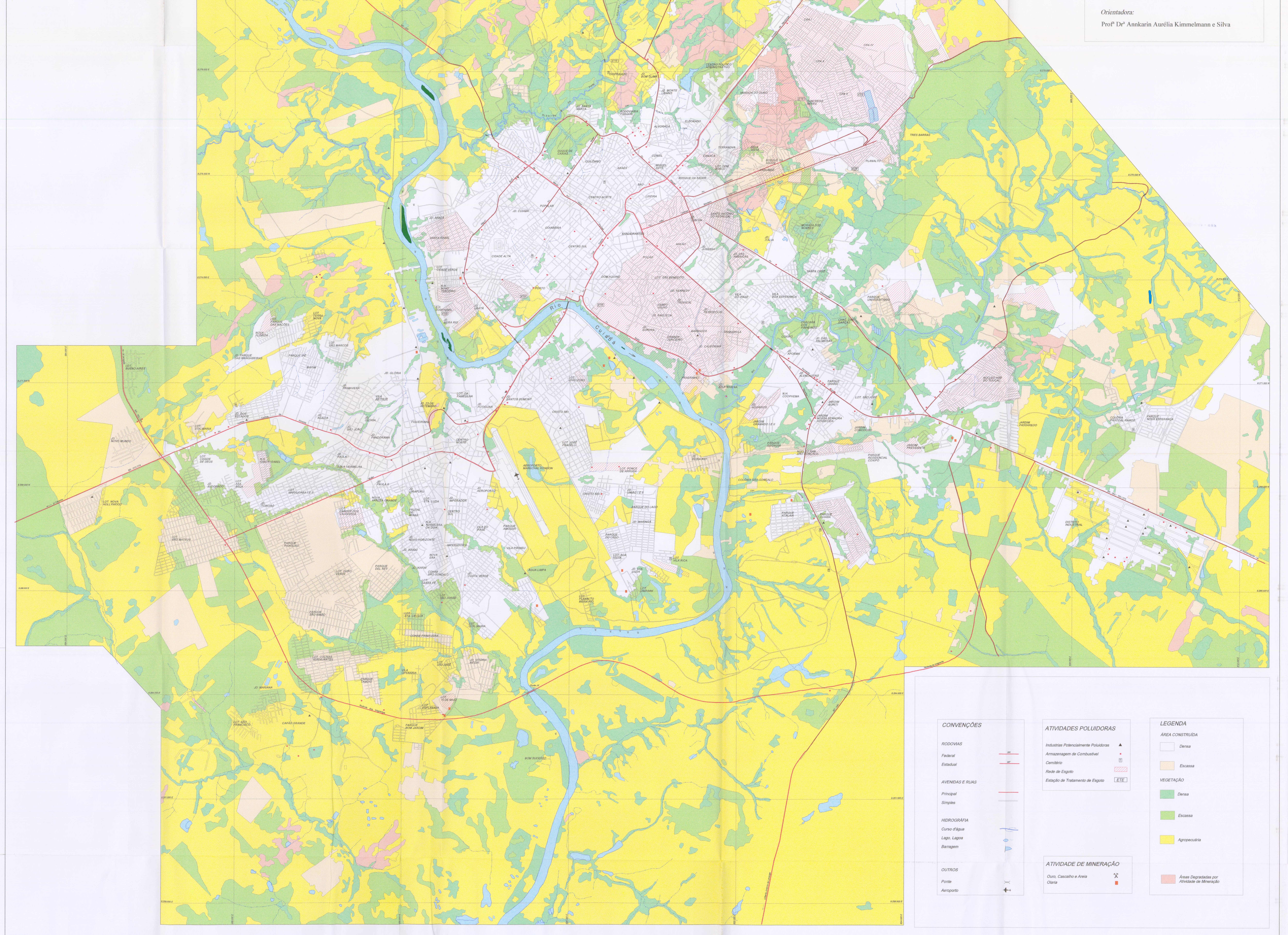



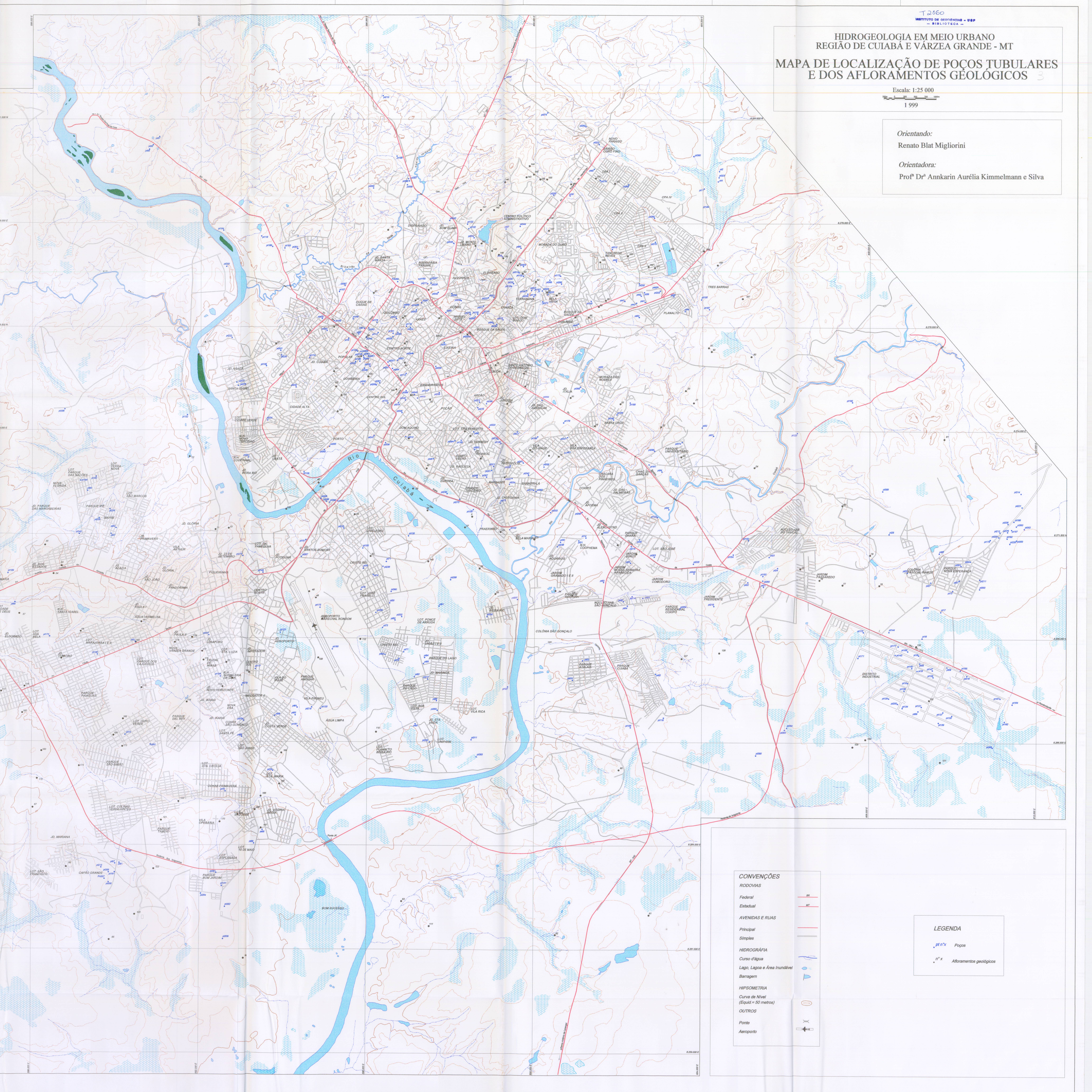

